\title{
Contribuição ao Diagnóstico do Cisto Ósseo Traumático
}

\author{
Eliete Neves da Silva
}

Dissertação apresentada à Faculdade de Odontologia de Bauru, da Universidade de São Paulo, como parte dos requisitos para obtenção do grau de Mestre em Odontologia, área Diagnóstico Bucal.

Orientador: Prof. Dr. José Humberto Damante

\author{
BAURU
}




\section{Eliete Neves da Silva}

28 de abril de 1970

Nascimento

Paraúna - Go

$1988-1992$

Curso de Graduação em Odontologia na Universidade Federal de Goiás.

$1995-1997$

Curso de Pós-graduação em Odontologia, área Diagnóstico Bucal, em nível de Mestrado na Faculdade de Odontologia de Bauru, Universidade de São Paulo.

Associações

ABO - Associação Brasileira de Odontologia - Seção Goiás

SOBE - Sociedade Brasileira de Estomatologia

SBPqO - Sociedade Brasileira de Pesquisas Odontológicas

IADR - International Association for Dental Research APG - FOB/USP - Associação de Pósgraduandos da FOB/USP 
Aos meus pais, José e Zilda

Responsáveis por darem ao meu viver um significado real e completo.

Pelo que representam na minha vida e na reafização do meu ideal acadêmico, tornando possível a conquista dos meus objetivos, dedico este trabalho.

Meu eterno amor, respeito e admiração 


\section{Minha profunda gratidão}

Às minhas irmãs, Elaine e Estela, pelo grande incentivo e compreensão nos momentos de lutas e dificuldades, demonstrando sempre nosso grande amor. Tenho um profundo orgulho em ver onde chegamos, juntas. Dedico-lhes também esta grande conquista.

À minha família, pelo carinho e apoio, em especial à minha avó Cota, às minhas tias e amigas Zuleide, Zeusa e Zenaide, à minha madrinha Fia, às primas Joana, Sília e Flávia e aos meus cunhados Hugo e Carlos, com os quais convivi mais de perto.

Às minhas "irmãs de Bauru", Maria Alves G.S. Silva, Lilian Neuvald, Maria do Carmo M.

Guimarães, Marly Kimie Sonohara, Graziela de Luca Canto e Evelyn Lucas Gonçalves, sou eternamente grata pela paciência que tiveram com as minhas ansiedades, sendo além de amigas companheiras e colaboradoras. Meu eterno carinho e admiração. 
Ao meu orientador e Pai científico

Prof. Dr. José Humberto Damante, terei sempre em mente sua eterna disponibilidade e abnegação, marcando minha formação profissional com exemplos de dignidade, honestidade e competência.

Minha gratidão, respeito e carinho. 
Minha admiração e agradecimento

Ao meu eterno professor e querido amigo Elismauro Francisco de Mendonça por ter me ensinado a amar a Estomatologia e guiado, há muitos anos, todos os meus passos, estendendo-me a mão com incentivo e apoio nos momentos de dificuldade. Meu carinho e fidelidade.

À minha querida amiga, "irmã" e colega Maria Alves G. S. Silva, "ponto de equilíbrio" durante os momentos difíceis. Com certeza seria impossivel a conclusão do meu Mestrado sem o seu solícito e constante apoio emocional. Será sempre o meu exemplo de força, luta e competência, merecendo, juntamente com seu filho Felipe, todo o meu amor.

Ao Prof. Dr. Orivaldo Tavano, coordenador do curso de pós-graduação em Diagnóstico Bucal, o meu agradecimento pela maneira carinhosa com que sempre me acolheu e a minha admiração por sua capacidade em suavizar os momentos dificeis com palavras de apoio e otimismo. 
Nada é conhecido por adivinhação; e não se acredita que desde os primórdios da ciência até o presente momento, uma única idéia correta tenha emanado de suposições; é correto entretanto, que aqueles que estão pesquisando deveriam saber que não há caminhos curtos ou isolados para a busca do conhecimento.

Àqueles que foram parte essencial na elaboração deste trabalho, conseguindo atribuir valores científicos e estatísticos que contribuem no esclarecimento de tantas dúvidas e indagações. Assim, agradeço imensamente:

Ao Prof. Dr. José Humberto Damante (Bauru), Prof. Dr. Luiz Casati Alvares (Bauru), Prof. Dr. José Simões Barroso (Bauru), Prof. Dr. Reinaldo Mazzottini (Bauru), CD Wesley Cabral Rocha (Goiânia), CD Lucy Aparecida Parreira Martins (Goiânia), Prof. Wilson Denis Martins (Curitiba), Prof. Angelo José Pavan (Maringá), Prof. Liogi Iwaķi Filho (Maringá), Prof. Edevaldo Tadeu Camarine (Maringá), CD João de Góes (Florianópolis).

Aos Professores e Funcionários da Disciplina de Ortodontia da Faculdade de Odontologia de Bauru USP, por permitir o acesso aos seus arquivos.

Aos examinadores do trabalho, Isabel Maria March de Carvalho, Maria Alves G.S.Silva, Osny Ferreira Júnior e Pedro Gregol da Silva. 


\section{Agradecimentos especiais}

À Profa. Dra. Ana Lúcia A. Capelozza e ao Prof. Dr. Luiz Eduardo Montenegro Chinellato, pelo apoio e incentivo.

Aos funcionários do Departamento de Estomatologia, Walderez, Marília, Fernanda, Célio e Zezinho, pelo carinho e amizade que sempre demonstraram e sobretudo pela seriedade profissional.

Aos colegas da Pós-graduação: Osny, Lúcio, Edevaldo, Paulinho, Maria, Liogi, Guilherme, Gilferto, Isabel, Pedrão, Angelo e Vanessa, pela alegria de compartilhar os bons e dificeis momentos.

Aos professores da Faculdade de Odontologia da Universidade Federal de Goiás, responsáveis pela minha formação acadêmica, em especial à Profi. Drr. Teresinha Vasconcelos Campos, cuja amizade e carinho a mim dedicados, desde a graduação, só reforçaram a luta em prol da ciência.

Ao meu querido amigo Cláudio Leles e a seus pais Marilene e Lourival, que sempre me acolheram como se eu fosse da família, agradeço pela paciência , dedicação e carinho .

Aos amigos Estela, João e Mônica, companheiros inseparáveis em todos os momentos desta trajetória.

Aos amigos e companheiros de trabalho, José Valladares Neto e Flávia Aline Silva, cujo incentivo e apoio sempre me estimularam a seguir em frente. 
Aos primeiros amigos de Bauru, Eneida, Washington e Damé, pelo companheirismo nos momentos iniciais.

Aos professores, funcionários e colegas das Disciplinas de Patologia e Histologia da Faculdade de Odontologia de Bauru, por sempre terem me aberto as portas.

Aos funcionários da pós-graduação e da Biblioteca pela indispensável colaboração aos meus estudos. 
Agradecimento àqueles que participaram diretamente na elaboração do trabalho

Ao Antônio Fernando A. C. Lima pela dedicação e empenho com que realizou a reprodução fotográfica.

Ao senhor Valdir João Afonso, sempre cordial e eficiente, pela leitura e corrę̧ões do português.

Aos colegas Maria, Graziela, e Osny, pela leitura e correções suplementares.

À amiga Evelyn pela correção do Abstract.

Ao Marcus Thames pela competência com que sempre realizou as cópias dos meus trabalhos.

\section{Agradecimentos Administrativos}

Ao Prof. Dr. Dagoberto Sottovia Filho, Diretor da Faculdade de Odontologia de Bauru.

Ao Prof. Dr. Luís Fernando Pegoraro, Coordenador da Pós-graduação.

Ao CNPPq pelo auxílio financeiro.

$\mathcal{A}$ todos os professores e funcionários da Faculdade de Odontologia de Bauru, indispensáveis na minha

formação profissional. 


\section{SUMÁRIO}

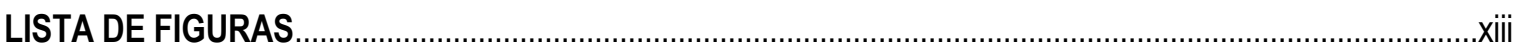

LISTA DE TABELAS

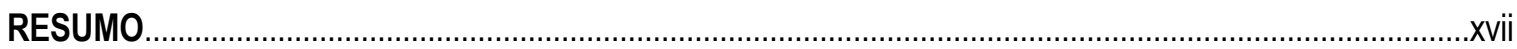

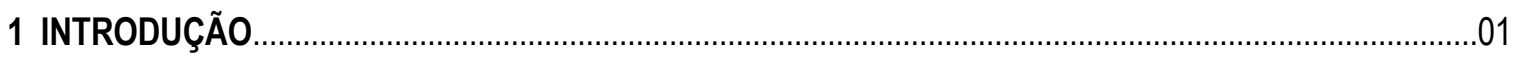

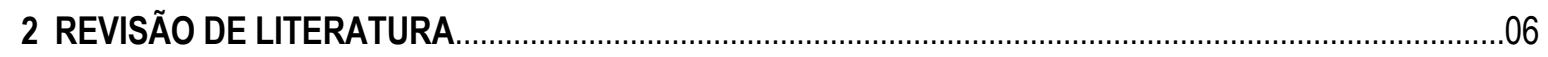

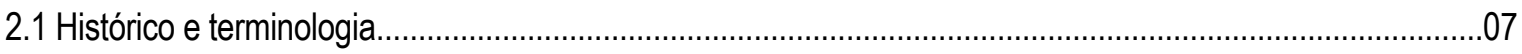

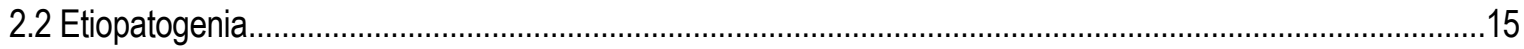

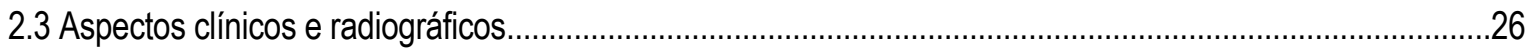

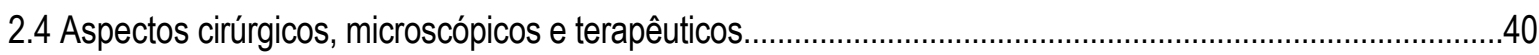

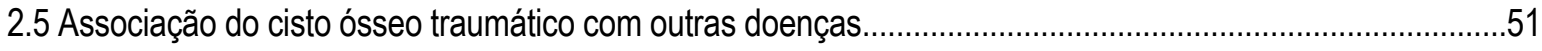

2.6 Relação com o cisto ósseo solitário (unicameral) dos ossos longos...........................................................52

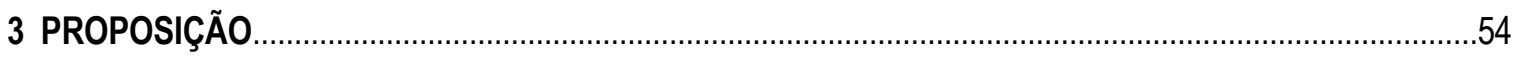

4 MATERIAL E MÉTODOS

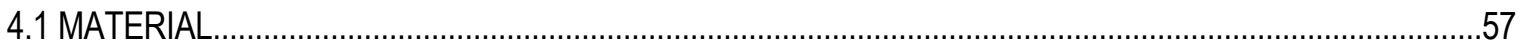

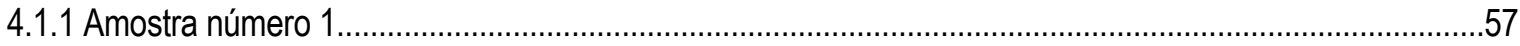

4.1.1.1 Critérios clínicos, radiográficos, cirúrgicos e de preservação aplicada àamostra número 1....................57

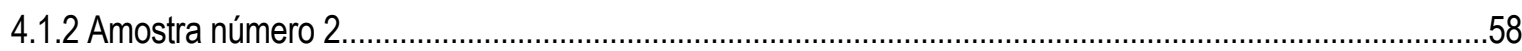

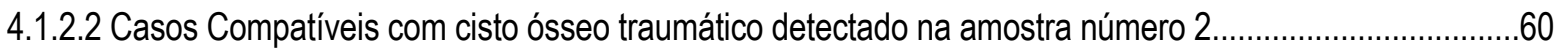

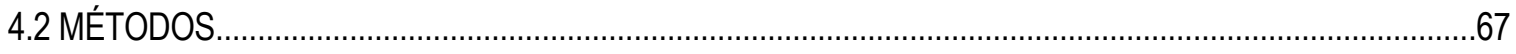

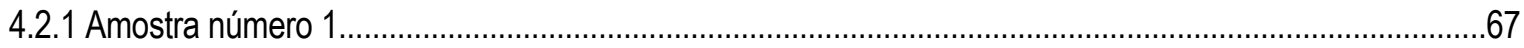

4.2.2 Amostra número 2

4.2.3 Amostra número 1 e 2 relacionadas as tratamento ortodôntico ............................................................68 


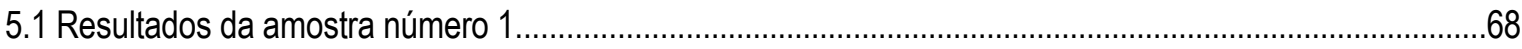

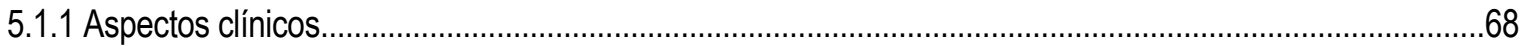

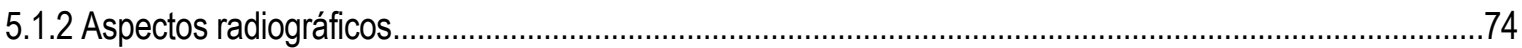

5.1.3 Proservação dos casos clínicos compatíveis com cisto ósseo traumático..............................................81

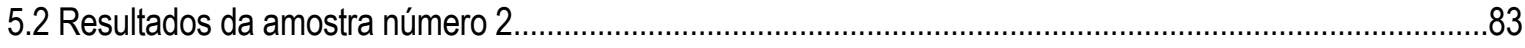

5.3 Amostras número 1 e 2 relacionadas ao tratamento ortodôntico.....................................................................

6 DISCUSSÃO

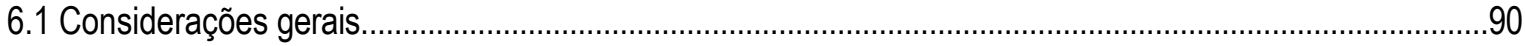

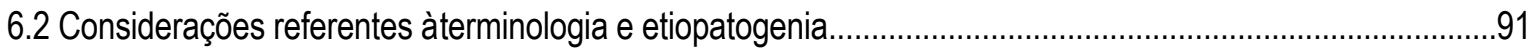

6.3 Relação entre o cisto ósseo traumático, gênero, raça e faixa etária..............................................................

6.4 Relação entre o cisto ósseo traumático e a história de trauma e/ou de tratamento ortodôntico da amostra

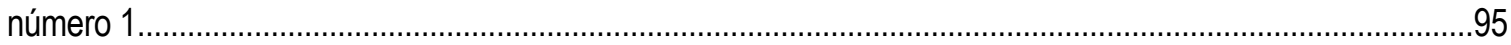

6.5 Diagnóstico do cisto ósseo traumático segundo o tipo de radiografia examinada.........................................97

6.6 Epidemiologia do cisto ósseo traumático, segundo localização e conformação da imagem

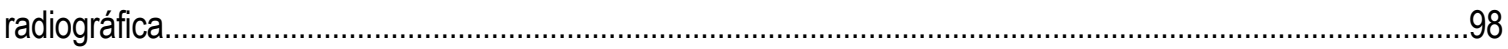

6.7 Critérios de diagnóstico e proservação dos casos clínicos compatíveis com cisto ósseo traumático da

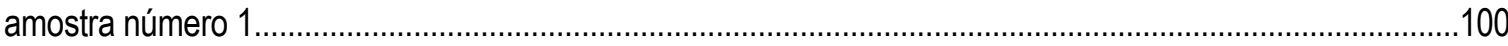

6.8 Relação do cisto ósseo traumático e o tratamento ortodôntico...................................................................103

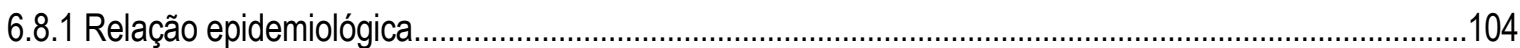

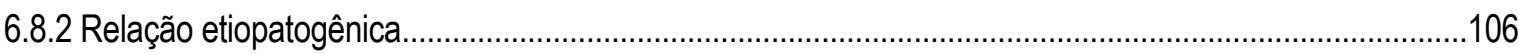

7 CONCLUSÕES

REFERÊNCIAS BIBLIOGRÁFICAS

ABSTRACT 


\section{LISTA DE FIGURAS}

FIGURAS 4.3 A e B- Radiografia oclusal de um caso de cisto ósseo traumático, A mostrando rarefação óssea atingindo a porção medular, sem expansão das corticais ósseas; B - leve adelgaçamento das corticais ósseas vestibular e lingual

FIGURA 4.4 Aspecto cirúrgico do cisto ósseo traumático, que revelou cavidade vazia, mostrando os ápices radiculares expostos na cavidade cística

FIGURAS 4.5 A e B - Exame radiográfico inicial $(A)$ e de dois anos de controle (B),apresentando involução da lesão

FIGURAS 4.6 A e B - Radiografia panorâmica demonstrando um caso da amostra número 2 considerado compatível com cisto ósseo traumático

FIGURA 5.1 -

Distribuição do número de pacientes e de casos clínicos de cisto ósseo traumático, quanto ao gênero

FIGURA 5.2 - $\quad$ Distribuição do número de pacientes e de casos clínicos de cisto ósseo traumático quanto àraça

FIGURA 5.3 -

Distribuição do número de pacientes e de casos clínicos de cisto ósseo traumático, quanto àfaixa etária

FIGURA 5.4 - Distribuição do número de pacientes e de casos clínicos de cisto ósseo traumático quanto à história de trauma, tratamento ortodôntico ou ausência de história

FIGURA 5.5 -

Distribuição dos pacientes portadores de cistos ósseo traumático quanto àhistória de tratamento ortodôntico em relação ao momento do diagnóstico

FIGURA 5.6 - $\quad$ Distribuição dos casos clínicos de cisto ósseo traumático, segundo o tipo de radiografia examinada

FIGURA 5.7 - Distribuição dos casos clínicos de cisto ósseo traumático, quanto à localização da doença
FIGURAS 4.1A e B - Radiografia panorâmica mostrando imagem radiolúcida oval na mandíbula, de contornos delimitáveis em quase toda extensão, raramente com halo radiopaco (orla esclerótica) e parcialmente presente, com aparência típica do cisto ósseo traumático
FIGURA 4.2 -
Radiografia periapical demonstrando o cisto ósseo traumático, estendendo se por entre as raízes dentárias, de aspecto crenado ("scalloping")

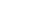
64 
FIGURA 5.8 -

FIGURA 5.9 -

FIGURA 5.10 -

FIGURA 5.11 -

FIGURA 5.12 -

FIGURA 5.13 -
Distribuição dos casos clínicos de cisto ósseo traumático segundo a conformação da imagem em radiografias panorâmicas

Representação esquemática das radiografias de diagnóstico dos casos de cisto ósseo traumático, segundo a localização, tamanho e conformação da lesão

Representação esquemática das radiografias de diagnóstico dos casos de cisto ósseo traumático, segundo a localização, tamanho e conformação da lesão

Representação esquemática das radiografias de diagnóstico dos casos de cisto ósseo traumático, segundo a localização, tamanho e conformação da lesão

Distribuição de 956 pacientes com tratamento ortodôntico concluído, quanto àfaixa etária, detectada no início do tratamento ortodôntico

Distribuição da somatória dos casos da amostra número 1 e 2 envolvidos com 0 tratamento ortodôntico e sua relação com 0 momento do diagnóstico
78

77

79

80

84

88 


\section{LISTA DE TABELAS}

TABELA 2.1 - Distribuição dos autores entre as diversas terminologias atribuídas ao 14 cisto ósseo traumático, em suas respectivas publicações

TABELA 2.2 - Distribuição das principais teorias e seus autores, referentes à etiopatogenia do cisto ósseo traumático na literatura em relação ao ano e autores

TABELA 5.1 - Distribuição do número de pacientes e de casos clínicos de cisto ósseo traumático, quanto ao gênero

TABELA 5.2 - Distribuição do número de pacientes e de casos clínicos de cisto ósseo traumático quanto a raça traumático, quanto àfaixa etária

TABELA 5.4 - Distribuição do número de pacientes e de casos clínicos de cisto ósseo traumático quanto à história de trauma, tratamento ortodôntico ou ausência de história

TABELA 5.5 - Distribuição dos pacientes portadores de cisto ósseo traumático quanto à história de tratamento ortodôntico em relação ao momento do diagnóstico

TABELA 5.6 - Distribuição dos casos clínicos de cisto ósseo traumático, segundo o tipo de radiografia examinada

TABELA 5.7 - Distribuição dos casos clínicos de cisto ósseo traumático, quanto à localização da doença

TABELA 5.8 - Distribuição dos casos clínicos de cisto ósseo traumático segundo a conformação da imagem em radiografias panorâmicas

TABELA 5.9 - Distribuição dos casos clínicos compatíveis da amostra número 1, quanto ao tempo de proservação, estado atual da imagem radiográfica e sintomatologia

TABELA 5.10 - Distribuição de 956 pacientes com tratamento ortodôntico concluído, quanto àfaixa etária, detectada no início do tratamento ortodôntico

TABELA 5.11 - Distribuição das opiniões de quatro examinadores (especialistas em

Radiologia) sobre a compatibilidade com o diagnóstico radiográfico de cisto ósseo traumático: Estudo de oito cistos levantados, entre 956 pacientes com tratamento ortodôntico concluído 
TABELA 5.12 - Momento em que foi detectada a imagem radiográfica compatível com cisto ósseo traumático em relação à etapa do tratamento ortodôntico: Estudo de oito cistos levantados, entre 956 pacientes com tratamento ortodôntico concluído

TABELA 5.13 - Distribuição do somatório dos casos da amostra número 1 e 2 envolvidos com o tratamento ortodôntico e sua relação com 0 momento do diagnóstico 


\section{RESUMO}

Uma pesquisa sobre o cisto ósseo traumático foi realizada com os seguintes objetivos: (1) Estabelecer a epidemiologia da amostra estudada, quanto ao gênero, raça, faixa etária, história clínica, localização e conformação da imagem radiográfica. (2) Discutir as possibilidades de cura espontânea da doença, sugerindo critérios para a proservação das lesões não tratadas cirurgicamente. (3) Estudar a prevalência do cisto ósseo traumático em pacientes tratados ortodonticamente e discutir sua possível relação etiopatogênica. O material constituiu-se de duas amostras. A amostra número 1, de procedência heterogênea, foi composta por 28 casos de cisto ósseo traumático, sendo 19 comprovados cirurgicamente, e nove casos compatíveis com a doença, pelos aspectos clínicos, radiográficos e de proservação. A amostra número 2 foi constituída por 8 casos encontrados entre 956 pacientes com tratamento ortodôntico concluído. Os resultados referentes à amostra número 1 permitiram verificar que: (1) não houve uma diferença significante na prevalência do cisto ósseo traumático em relação ao gênero; (2) o cisto ocorreu predominantemente na raça branca, porém houve uma relação entre lesões bilaterais e mulheres negras; (3) 22 casos apareceram em pacientes na 2a década de vida; (4) 69,23\% dos pacientes apresentavam história de tratamento ortodôntico e 30,77\% de trauma; (5) a localização principal da lesão foi o corpo mandibular com imagens radiográficas uniloculares e de forma oval; (6) a proservação dos casos compatíveis com 0 diagnóstico de cisto ósseo traumático revelou imagens estáticas ou em regressão; (7) os seguintes critérios de proservação foram sugeridos: (a) exame clínico e radiográfico 20 dias após a descoberta da lesão, sem sintomatologia constatável e com imagem radiográfica estável comparável àimagem de diagnóstico; (b) exame clínico e radiográfico de 60 dias mantendo as características iniciais ou mostrando involução da lesão; (c) exame clínico e radiográfico de seis meses mantendo as características iniciais ou de involução da lesão; (d) controle de um ano ou mais, repetindo aspectos já mencionados. Os resultados referentes à amostra número 2 mostraram uma alta prevalência do cisto ósseo traumático em pacientes tratados ortodonticamente, porém $50 \%$ dos casos foram detectados na documentação ortodôntica inicial. Assim pode-se concluir: (1) o maior acesso da população ao tratamento odontológico especializado permite a detecção de lesões, até então, consideradas raras; (2) o ortodontista desempenha um importante papel no diagnóstico do cisto ósseo traumático. 
1 - INTRODUCÃO 


\section{INTRODUÇÃO}

Há muito tempo, os cistos dos maxilares são reconhecidos como um problema clínico. A partir do século XX, um grande número de publicações a respeito do assunto tem sido realizado, refletindo o aumento de interesse quanto à etiopatogenia, comportamento biológico, diagnóstico e tratamento desse grupo de doenças ${ }^{112}$. Antes de 1929, pensava-se que todos os cistos dos maxilares eram de origem odontogênica, até que $\mathrm{BLUM}^{11}$ questionou este fato, relatando dois casos clínicos de cistos não odontogênicos. Neste mesmo artigo, discutindo sobre a questão, Lucas descreveu na literatura o primeiro caso clínico, denominado, posteriormente, "cisto ósseo traumático"11.

O cisto ósseo traumático foi classificado, em 1992, pela Organização Mundial de Saúde $(\mathrm{OMS})^{64}$, como uma das lesões ósseas não neoplásicas, juntamente com a displasia fibrosa, as displasias cementósseas, o querubismo, o granuloma central de células gigantes e o cisto ósseo aneurismático, com as sinônimas de "cisto ósseo solitário", "cisto ósseo simples" e "cisto ósseo hemorrágico". SHEAR ${ }^{112} 0$ incluiu entre os cistos não odontogênicos, sem revestimento epitelial, pois não considera a necessidade de revestimento epitelial na sua definição genérica de cisto.

O cisto ósseo traumático não é uma lesão incomum, com uma prevalência de $1 \%$ dos cistos dos maxilares ${ }^{112}$. Aparece mais freqüentemente durante a segunda década de vida, sendo raro após os 25 anos de idade. Ocorre, quase que exclusivamente, na mandíbula, com predileção pelo corpo e sínfise mandibular. 0 cisto ósseo traumático é assintomático, sendo diagnosticado em exame radiográfico de rotina. Radiograficamente, apresenta-se como uma área radiolúcida, unilocular, bem definida, 
geralmente com contornos crenados ("scalloping"), principalmente entre as raízes dos pré-molares e molares. Está quase sempre contido no osso medular, sendo raro a presença de expansão das corticais ósseas. As paredes císticas são recobertas por um tecido conjuntivo frouxo tênue, podendo conter células gigantes multinucleadas e grânulos de hemossiderina. $O$ tratamento de escolha é a exploração cirúrgica, pois permite a confirmação do diagnóstico clínico e radiográfico após a inspeção da cavidade, que quase sempre é vazia. Com a exploração cirúrgica preenche-se a cavidade com sangue e o reparo logo é consumado1,2,3,5,14,16,18,19,20,21,23,24,28,31,32,37,40,42,43,48,61,65,70,71,78, $79,98,100,105,106$.

A etiopatogenia do cisto ósseo traumático permanece desconhecida, refletindo assim a variedade de nomes encontrados na literatura, "cisto ósseo traumático", "cisto ósseo solitário", "cisto ósseo hemorrágico", "cisto de extravasamento", "cisto ósseo idiopático", "cisto ósseo simples", "cavidade óssea idiopática", "cisto ósseo primário", entre outros. Múltiplas hipóteses têm sido propostas, mas nenhuma delas apresenta comprovação científica. Apesar de não totalmente aceita, a mais difundida é a hipótese da ocorrência de uma hemorragia intramedular com falha na organização do hematoma, e conseqüente liquefação do coágul053,86. Existem argumentos contrários a esta proposta para a etiopatogenia do cisto ósseo traumático, particularmente pelo fato de ser difícil constatar a história de trauma. Não obstante, parece que em alguns casos o trauma ou outros estímulos são os fatores iniciantes, levando à ru ptura da fina parede dos sinusóides, ocorrendo assim, hemorragias intramedulares ${ }^{112}$.

Em 1946, RUSHTON 104 propôs os critérios que definiram o cisto ósseo traumático como uma lesão cística simples, não revestida por epitélio, contendo principalmente fluido e não tecido mole, delimitada por paredes ósseas, sem evidências 
de infecção aguda ou prolongada. Embora estes critérios ainda sejam aceitos até hoje, 0 conceito do cisto ósseo traumático necessita ser reavaliado, pois há polêmicas relativas ao diagnóstico, comportamento biológico e formas de tratamento. Por exemplo, alguns casos têm sido publicados na literatura mostrando a resolução espontânea desta doença. $\mathrm{Na}$ discussão, os autores justificam tal possibilidade pela raridade em pacientes adultos, o que atesta a autolimitação da doença e levanta questão sobre a real necessidade do tratamento cirúrgico $107,117$.

A literatura atual tem sido falha em pesquisar sobre este tema. Nota-se apenas o relato de casos clínicos e revisões da literatura. Se fossem realizadas mais pesquisas científicas transversais e longitudinais, com melhores critérios de diagnóstico e proservação, as dúvidas pertinentes, ainda hoje sobre 0 assunto, talvez tivessem sido solucionadas. Critérios confiáveis de diagnóstico e proservação merecem ser estudados para que se aprofunde o conhecimento sobre o comportamento biológico da doença, e evitem-se intervenções desnecessárias, cruentas e traumáticas para os pacientes.

Por tratar-se de uma lesão assintomática, quase sempre descoberta em exames radiográficos de rotina, a radiografia desempenha um importante papel no diagnóstico do cisto ósseo traumático. 0 valor da radiografia fica ainda mais reforçado com as referências sobre a cura espontânea dessa doença, pois a proservação é calçada, particularmente neste exame complementar.

Outro aspecto polêmico sobre o cisto ósseo traumático é o seu constante aparecimento em pacientes durante 0 tratamento ortodôntico. A literatura não relata este fato, freqüentemente observado na rotina das clínicas de Radiologia e Estomatologia da FOB/USP. Seria a documentação ortodôntica a razão de se detectar 
esta doença assintomática? A movimentação dentária induzida participaria na sua etiopatogenia? Percebe-se que estudos transversais e longitudinais merecem ser levados a efeito. 
$\underline{\text { 2-REVISÃO DE LITERATURA }}$ 


\section{REVISÃO DE LITERATURA}

Este capítulo revisa a literatura sobre o cisto ósseo traumático, enfocando o histórico, a terminologia, a etiopatogenia, bem como seus aspectos clínicos, radiográficos, cirúrgico, microscópicos e terapêuticos. A associação do cisto ósseo traumático com outras doenças e sua relação com o cisto ósseo solitário ou unicameral dos ossos longos também é abordada.

O objetivo desta revisão consiste em abordar as características desta lesão, polêmica em vários aspectos e ainda não totalmente esclarecida.

\subsection{Histórico e terminologia}

BLUM ${ }^{11}$, em 1929, questionou a origem odontogênica de todos os cistos dos maxilares, chamando, já nesta época, a atenção da necessidade da microscopia, para este esclarecimento. Neste trabalho, BLUM ${ }^{11}$ abriu a discussão para diversos autores que descreveram alguns cistos dos maxilares.

Uma doença que, segundo Lucas, não podia ser chamada de cisto, mas que deveria ser considerada nas discussões sobre cisto foi descrita em 1929. Naquele momento, foi relatado o primeiro caso clínico desta doença, posteriormente, denominada "cisto ósseo traumático"11. BLUM"11 enfatizou que "o chamado cisto ósseo" descrito por Lucas foi causado por trauma, seguido de hemorragia, formando uma cavidade óssea, não sendo assim um cisto verdadeiro. 
Três anos depois BLUM ${ }^{10}$ utilizou, primeiramente, o termo "cisto ósseo traumático", relatando três casos clínicos, semelhantes àquele descrito por Lucas anteriormente ${ }^{11}$. A similaridade microscópica destes três casos clínicos, com o cisto ósseo traumático dos ossos longos, determinou a escolha desta terminologia pelo autor ${ }^{10}$. Todos os três pacientes possuiam história de trauma, reforçando a terminologia e 0 provável fator etiológico da lesão.

Os cistos dos maxilares foram classificados etiologicamente, clinicamente e histopatologicamente, por JACOBS; STONE ${ }^{54}$, em 1940. O "cisto ósseo traumático" foi definido como uma cavidade revestida por tecido conjuntivo, contendo produtos de decomposição do sangue.

Um estudo detalhado sobre o "cisto ósseo solitário" foi realizado por RUSHTON104, em 1946, questionando se esta seria uma lesão distinta, representando um grupo homogêneo, ou se seria similar ao cisto ósseo solitário dos ossos longos. 0 autor ${ }^{104}$ propôs os seguintes critérios para o diagnóstico desta entidade:

$\Rightarrow$ o cisto deveria ser simples;

$\Rightarrow$ não deveria ser revestido por epitélio;

$\Rightarrow$ não deveria apresentar evidência de infecção aguda ou prolongada;

$\Rightarrow$ deveria conter, principalmente, fluido e não tecido mole;

$\Rightarrow$ as paredes deveriam ser de osso, embora delgado em algumas áreas;

$\Rightarrow$ os achados patológicos e químicos não deveriam excluir o diagnóstico de "cisto ósseo solitário".

Com as características acima, 20 casos clínicos de "cisto ósseo traumático" já haviam sido publicados na literatura mundial até 1951. Neste mesmo ano, OLECH et al. ${ }^{86}$ acrescentaram mais oito novos casos à literatura e discutiram aqueles 
descritos anteriormente. Dos 28 casos relatados, 21 apresentavam história de trauma na região afetada, reforçando o trauma como principal agente etiológico.

Um simpósio ${ }^{123}$ foi realizado em 1955, com a finalidade de obter um consenso de opiniões sobre os achados clínicos, investigação radiográfica, estudo histopatológico e melhores tipos de tratamento para várias doenças. 0 tema escolhido foi o "cisto ósseo traumático", devido ao pouco conhecimento, raridade e controversas sobre a doença. Vários autores $4,6,9,56,62,85,122,123,128,130$ participaram do simpósio com a publicação de dez artigos, com os quais concluíram:

$\Rightarrow$ a nova terminologia, "cavidade óssea progressiva", proposta por WHINERY130 foi rejeitada por todos os participantes. $\mathrm{O}$ termo cisto foi aceito por patologistas bucais e gerais;

$\Rightarrow$ uma história prévia de trauma estava presente na maioria dos casos, podendo 0 trauma ter ocorrido anos antes do aparecimento do cisto;

$\Rightarrow$ os pacientes eram freqüentemente jovens, justificando a formação de hemorragia intra-óssea e não de fratura;

$\Rightarrow$ a localização de maior ocorrência foi a região entre 0 canino e 0 ramo da mandíbula;

$\Rightarrow 0$ cisto, geralmente, mostrava-se assintomático;

$\Rightarrow 0$ cisto persistia por um longo período. BLUM ${ }^{9}$ relatou a possibilidade de cura espontânea, sem nenhum tipo de intervenção, descartando assim o termo "cavidade óssea progressiva";

$\Rightarrow$ os achados radiográficos eram, freqüentemente, característicos. A formação de contornos crenados ("scalloping") entre os dentes era o achado mais comum, não se observando este aspecto em nenhuma outra lesão cística, ocorrendo principalmente entre as raízes dos molares e pré-molares; 
$\Rightarrow$ a lesão não apresentava revestimento e os nervos e vasos eram encontrados passando livremente pela cavidade;

$\Rightarrow$ o tratamento mais indicado era a abordagem cirúrgica;

$\Rightarrow$ a patogênese permanecia obscura.

GARDNER et al. ${ }^{37}$, em 1962, revisaram 45 casos clínicos de "cisto ósseo traumático", anteriormente descritos, e acrescentam mais 20 novos casos à literatura. Os autores ${ }^{37}$ chamaram a atenção para o fato do aspecto histopatológico ser meramente uma cavidade normal no osso.

Uma vasta revisão da literatura sobre o "cisto ósseo hemorrágico" foi realizada por HOWE ${ }^{52,53}$, em 1965, afirmando ser esta uma das lesões mais intrigantes, devido æ̀ dificuldades envolvidas no diagnóstico, terminologia e patogênese da doença. $O$ autor ${ }^{22,53}$ distinguiu três tipos de lesões chamadas "cistos ósseos solitários dos maxilares": a "cavidade óssea latente", o "cisto ósseo traumático ou hemorrágico" e o "cisto ósseo aneurismático". Seis novos casos foram acrescidos à literatura e 54, previamente publicados, foram revisados detalhadamente.

O primeiro relato minucioso de um caso de "cisto ósseo traumático" com cura sem cirurgia foi realizado por SZERLIP117, em 1966, defendendo assim a opinião de BLUM ${ }^{9}$, na qual o "cisto ósseo traumático" pode ter uma regressão espontânea. Ainda em 1966, o termo "cisto ósseo idiopático" foi acrescido àliteratura por ZEGARELLI et al. ${ }^{132}$, enfatizando o desconhecimento da etiologia da doença. Uma série de 17 casos clínicos foi relatada, enfocando a importância da intervenção e inspeção cirúrgica no diagnóstico. 
Após 0 advento da radiografia panorâmica tornou-se evidente que o "cisto ósseo traumático" não era uma lesão tão rara, como pensado anteriormente, possibilitando, assim, a descoberta de um número maior de casos, como os 22 casos descritos por MORRIS et al. ${ }^{79}$, em 1970. Estes autores ${ }^{79}$ destacaram que sinônimos variados refletem a divergência de opiniões quanto aos fatores causais da doença. 0 termo "cisto ósseo traumático" foi empregado apenas por ser o mais utilizado na literatura e não porque os autores concordassem com essa terminologia.

Uma revisão de literatura, realizada por HUEBNER; TURLINGTON54, em 1971, revela a existência de apenas 150 casos de "cisto ósseo traumático" relatados a partir de 1929, atestando a relativa raridade da doença. Acrescentaram dois casos incomuns à literatura: um associado a um "granuloma reparativo de células gigantes" e outro de dois cistos mandibulares no mesmo paciente.

Sessenta e seis novos casos de "cisto ósseo traumático" foram apresentados por HANSEN et al. ${ }^{43}$, em 1974, e comparados com os achados de mais de 150 casos previamente descritos na literatura com várias terminologias. Os autores enfatizaram, mais uma vez que a divergência de terminologia era decorrente do desconhecimento da etiopatogenia, ressaltando que os trabalhos publicados pareciam favorecer o termo "cisto ósseo traumático". Segundo os autores, descobertas futuras poderiam provar que o termo seria incorreto. 
Em seu extenso trabalho sobre a displasia óssea florida (34 pacientes), MELROSE et al. ${ }^{74}$, em 1976, relataram 17 casos de "cisto ósseo simples" associados àdisplasia óssea florida, destacando a diferença no comportamento biológico destes casos, quando comparados àqueles relatados anteriormente na literatura $10,11,37,43,52,53,79,132$.

Ainda em 1976, BEASLEY5 relatou 30 casos de "cisto ósseo traumático", apresentando detalhes clínicos e microscópicos. A maioria dos casos não estava associada a trauma ou hemorragia com resultante lise óssea. A história clínica era inconsistente e a falta de evidências microscópicas suficientes para sugerir episódios prévios de trauma. A designação do processo patológico como um "cisto ósseo traumático" foi julgada imprópria e o termo mais genérico "cisto ósseo solitário" foi sugerido pelo autor 5 .

Um total de 161 casos de "cisto ósseo traumático", sendo 94 de revisão da literatura e 67 novos casos, foram analisados clínica e microscopicamente, por KAUGARS; CALE61 em 1987. Nesta pesquisa, afirmaram que os critérios propostos por RUSHTON ${ }^{104}$, em 1946, eram ainda aceitos, exceto a existência de lesões múltiplas e a presença de inflamação em alguns casos.

Um importante parâmetro entre o "cisto ósseo traumático", 0 cisto ósseo aneurismático e o granuloma central de células gigantes foi traçado por STIMSON; MCDANIEL ${ }^{115}$, em 1989. O trabalho analisou as características clínicas, radiográficas e microscópicas destas três lesões, e sugeriu a possibilidade de uma patogênese comum. 
Um novo enfoque com relação ao comportamento biológico do "cisto ósseo traumático" foi enfatizado por SAPP; STARK ${ }^{107}$, em 1990, relatando a cura espontânea de dois pacientes. Apesar de muitos investigadores $30,43,52,90$ sugerirem a possibilidade de cura espontânea do cisto ósseo traumático, raros casos têm sido descritos nos quais as lesões regrediram na ausência de qualquer intervenção 107, 117.

$\mathrm{Na}$ segunda edição da $\mathrm{OMS}^{64}$ referente aos tipos histopatológicos dos tumores e cistos odontogênicos e certas lesões ósseas dos maxilares, publicada em 1992, o "cisto ósseo solitário (traumático, simples, hemorrágico)" foi classificado como uma lesão óssea não neoplásica. Neste mesmo ano, SHEAR ${ }^{112} 0$ incluiu entre os cistos não epiteliais, já que 0 autor ${ }^{112}$ excluiu a obrigatoriedade de revestimento epitelial em sua definição de cisto.

O conceito de "cisto ósseo simples" foi reavaliado por SAITO et al. ${ }^{106}$, em 1992, devido क̀ múltiplas ocorrências e à sua associação com as lesões fibrósseas. Os autores ${ }^{106}$ demonstraram que 0 "cisto ósseo simples" pode apresentar comportamentos biológicos diferentes, representando um grupo heterogêneo de lesões com causas distintas.

DONKOR; PUNNIA-MOORTHY25, em 1994, propuseram que a terminologia do "cisto ósseo simples" fosse baseada em seu conteúdo, sendo os cistos vazios chamados "cistos idiopáticos", os cistos com conteúdo sólido denominados de acordo com suas características microscópicas e, aqueles contendo fluido, com um perfil bioquímico similar ao soro, chamados "cisto de extravasamento". 
A Tabela 2.1 mostra a distribuição das diversas terminologias atribuídas ao cisto ósseo traumático, em suas respectivas publicações.

TABELA 2.1 - Distribuição dos autores entre as terminologias atribuídas ao cisto ósseo traumático, em suas respectivas publicações. Os nomes estão listados de acordo com a ordem cronológica de aparecimento na literatura

\begin{tabular}{|c|c|c|}
\hline TERMINOLOGIA & AUTORES & $T^{*}$ \\
\hline Cavidade óssea & BLUM $^{10}$ (1932) & 1 \\
\hline Cisto ósseo traumático & 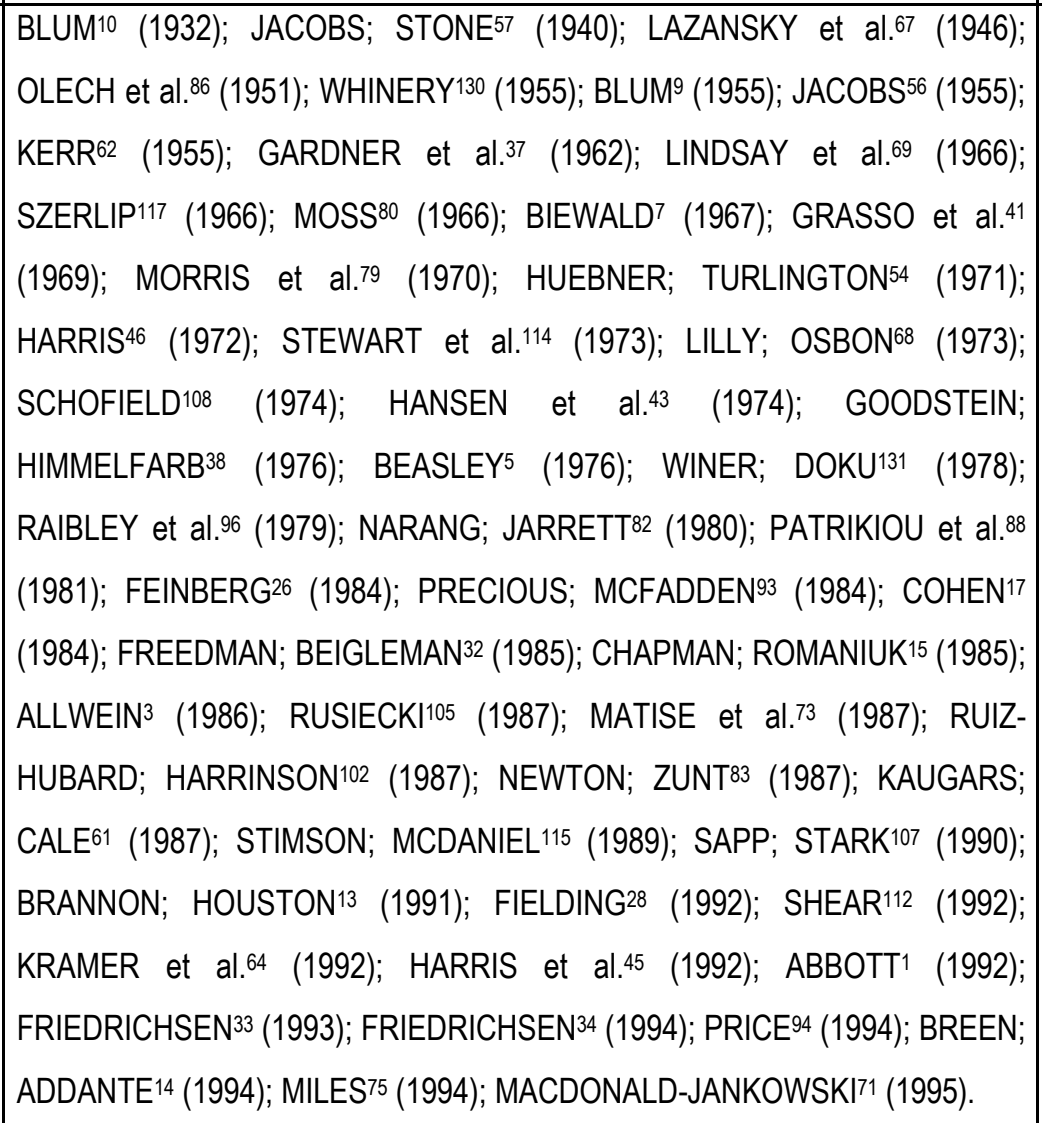 & 52 \\
\hline Cisto ósseo solitário & $\begin{array}{l}\text { RUSHTON104 (1946); WALDRON }{ }^{129} \text { (1954); GAIT35 (1976); POGREL90 (1978); } \\
\text { HOSSEINI51 (1978); BRADLEY12 (1982); PERSSON89 (1985); AKIMOTO et al. }{ }^{2} \\
\text { (1986); CUDIA et al.19 (1987); POGREL91 (1987); MOULE81 (1988); HARA et } \\
\text { al. } .^{44} \text { (1990); KUTTENBERGER et al. }{ }^{66} \text { (1992); SHEAR }{ }^{112} \text { (1992); KRAMER et } \\
\text { al. } .^{64} \text { (1992); LUDWIG; MERTEN70 (1995). }\end{array}$ & 16 \\
\hline Cisto unicameral & JAFFE; LICHTENSTEIN59 (1942). & 1 \\
\hline
\end{tabular}




\begin{tabular}{|c|c|c|}
\hline Cisto ósseo hemorrágico & 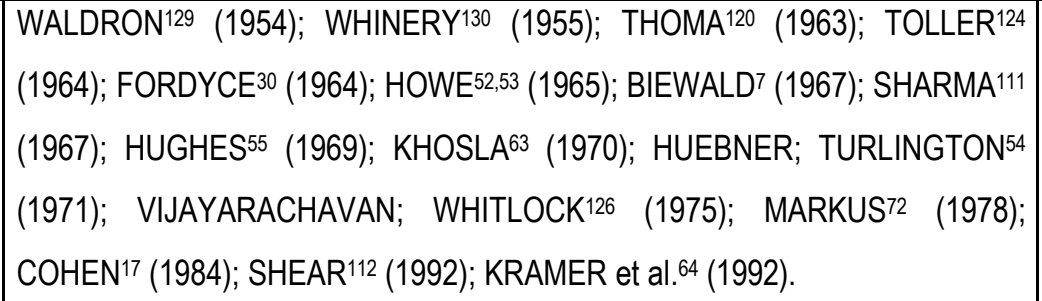 & 16 \\
\hline $\begin{array}{c}\text { Cavidade óssea } \\
\text { progressiva }\end{array}$ & WHINERY130 (1955). & 1 \\
\hline Cisto de extravasamento & THOMA $^{122}(1955)$ & 1 \\
\hline $\begin{array}{c}\text { Cisto de extravasamento } \\
\text { hemorrágico }\end{array}$ & AUSTIN4 (1955); THOMA 120 (1960); THOMA ${ }^{121}$ (1969) & 3 \\
\hline Cavidade óssea traumática & KERR62 (1955) & \\
\hline Cisto ósseo idiopático & ZEGARELLI et al. ${ }^{132}$ (1966); BLUM ${ }^{8}$ (1968) & 2 \\
\hline Cisto ósseo progressivo & ROBINSON et al.99 (1967) & 1 \\
\hline Cisto ósseo simples & $\begin{array}{l}\text { POYTON65 (1965); BIEWALD7 (1967); COHEN17 (1970); RUPRECHT; REID }{ }^{103} \\
\text { (1975); MELROSE et al. }{ }^{74} \text { (1976); HILLERUP; HJORTING-HANSEN50 (1978); } \\
\text { HEIMDAHL }{ }^{47} \text { (1978); NORTJÉ et al.84 (1978); KUROI65 (1980) FORSSELL et } \\
\text { al..31 (1988); SHEAR } 112 \text { (1992); KRAMER et al. } .^{64} \text { (1992); SUEl et al. }{ }^{116} \text { (1994); } \\
\text { DONKOR; PUNNCA-MOORTHY25 (1994); MIYAUCHI et al. } .^{77} \text { (1995). }\end{array}$ & 15 \\
\hline Cavidade óssea solitária & O'NEIL ${ }^{87}(1968)$ & \\
\hline Cavidade óssea idiopática & CHOUKAS; ROMANO ${ }^{16}$ (1978); ROME et al. ${ }^{101}$ (1983); HARRIS et al. ${ }^{45(1992) . ~}$ & 3 \\
\hline Cisto ósseo primário & TELFER et al..$^{119}$ (1990). & 1 \\
\hline
\end{tabular}

$\overline{T^{*}=\text { Total }}$

\subsection{Etiopatogenia}

Desde as primeiras descrições do cisto ósseo traumático, sua etiologia foi relacionada àhistória de trauma ${ }^{10,11}$. JACOBS et al. ${ }^{57}$, em 1940, associaram a ocorrência da lesão a um trauma insuficiente para causar fratura da mandíbula, mas suficiente para levar a uma hemorragia intramedular. Neste trabalho ${ }^{57}$, descreveram 0 processo de formação do cisto ósseo traumático como uma osteólise progressiva, 
possivelmente derivada da liberação de enzimas osteolíticas nos espaços intramedulares, durante e após a hemorragia.

A predileção do aparecimento do cisto ósseo traumático por pacientes jovens em regiões de crescimento ativo induziu JAFFE; LICHTENSTEIN ${ }^{59}$, em 1942, a sugerirem algum distúrbio local do crescimento e desenvolvimento ósseo. Os autores $^{59}$ tentaram mostrar que o ciclo natural de vida do cisto ósseo traumático apresentava dois estádios. 0 primeiro estádio representava um crescimento ativo e 0 segundo um comportamento latente ou estático. Quando o cisto era tratado no segundo estádio ocorreria uma boa resposta ao tratamento, mas se tratado durante a fase de crescimento ativo, o reparo ósseo poderia falhar, sendo, æ̀ vezes, necessária uma segunda intervenção.

OLECH et al. ${ }^{86}$, em 1951, citaram três teorias desenvolvidas para explicar a etiologia do cisto ósseo traumático. O cisto originar-se-ia a partir da:

$\Rightarrow$ degeneração de tumores ósseos verdadeiros, como o condroma;

$\Rightarrow$ degeneração de crescimentos similares a tumores no osso, como o tumor de células gigantes;

$\Rightarrow$ seqüela de um hematoma intra-ósseo em um osso saudável.

Neste estudo detalhado sobre a etiopatogenia do cisto ósseo traumático, os autores ${ }^{86}$ reforçaram a etiologia traumática, elaborando sua hipótese a partir da premissa de que após o trauma ao tecido ósseo, ocorre uma hemorragia intramedular com falha na organização precoce do hematoma em alguns espaços medulares. $O$ trabeculado do osso esponjoso seria, então, lentamente reabsorvido pela atividade osteoclástica nas áreas periféricas e, pelo tempo que o tecido conjuntivo viável demora para entrar em contato com o hematoma, sofreria uma liquefação. Isto seria 0 
suficiente para a formação inicial do cisto, crescendo, subseqüentemente, devido à infiltração progressiva do edema, causada pela restrição da drenagem venosa. Segundo os autores, estes cistos se desenvolveriam após a agressão em áreas de osso esponjoso com medula hematopoieticamente ativa e limitada por uma densa cortical compacta. Isto poderia explicar a localização e idade de maior prevalência do cisto ósseo traumático.

Teorias a respeito da etiologia do cisto ósseo traumático, foram apresentadas por WHINERY130, em 1955, para explicar a formação desta lesão. As seguintes teorias foram discutidas:

$\Rightarrow$ Teoria do cisto traumático-hemorrágico;

$\Rightarrow$ Teoria da formação cística a partir da degeneração de tumores;

$\Rightarrow$ Teoria dos cistos resultantes do metabolismo anormal do cálcio;

$\Rightarrow$ Teoria da necrose medular devido àisquemia;

$\Rightarrow$ Teoria da formação cística, resultante de uma infecção de baixo grau;

$\Rightarrow$ Teoria da osteoclasia resultante de um distúrbio circulatório (não hematoma) causado por trauma.

Durante o simpósio de 1955 , os autores $4,6,9,56,62,85,122,123,128$ concluíram que a patogênese deste cisto permanecia obscura, com improváveis evidências para apoiar as teorias discutidas por WHINERY130, sendo necessários estudos futuros para melhores elucidações.

Trabalhos anteriores $9,56,120$ acreditavam que os produtos da hemólise dos hematomas produziam uma pressão osmótica local, levando ao crescimento cístico. TOLLER ${ }^{124}$, em 1964, confirmou experimentalmente que: (1) a pressão hidrostática do cisto ósseo traumático era excepcionalmente baixa e comparável àpressão capilar, diferindo de outros cistos dos maxilares; (2) a tensão osmótica do fluido do cisto ósseo traumático era maior que aquela do sangue do paciente, e constituía em 
uma pequena, mas definida pressão expansiva; (3) a parede do cisto agia como uma membrana semipermeável, apesar da ausência de revestimento epitelial.

HOWE ${ }^{53}$, em 1965, admitiu a possibilidade da existência de mais de uma etiologia para o cisto ósseo traumático, não havendo uma mesma seqüência de eventos para a formação da lesão. Dividiu a discussão a respeito das teorias que tentaram explicar a patogênese do cisto ósseo traumático em três estádios:

A. Formação da cavidade dentro do osso - As hipóteses mais amplamente aceitas para explicar a formação do cisto ósseo traumático, foram aquelas pressupondo o desenvolvimento a partir de uma hemorragia intramedular. Esta teoria estaria dependente da existência de uma cortical óssea intacta para a ocorrência de uma pressão intra-óssea, sendo um dos fatores determinantes do equilíbrio entre reabsorção e deposição de osso na área afetada, como ocorrida na movimentação ortodôntica, com aplicação de pressão para promover a atividade osteoclástica. A reabsorção também seria devida, parcialmente, àquebra de produtos da hemólise e aumento na concentração de íons hidrogênio. $O$ osso viável, sendo constantemente reabsorvido, não haveria necessidade da presença de necrose do osso trabecular e medula óssea para explicar a formação da cavidade. Pareceu claro indicar que 0 trauma pode ser o fator inicial ao menos em uma parte dos casos. A possibilidade do cisto ósseo traumático ocorrer na região apical dos dentes ântero-inferiores submetidos a trauma oclusal excessivo foi também levantada.

B. Expansão da lesão dentro do osso - A mais provável explicação da expansão foi a pressão mais alta dentro da cavidade do que a pressão dos tecidos adjacentes, em alguns estádios na evolução da lesão. A cavidade óssea então formada aumenta por meio da ação osteoclástica associada à transudação de proteínas moleculares do sangue para dentro da cavidade. Posteriormente, este fluido é absorvido pela ação celular, deixando uma cavidade vazia dentro do osso. 
C. Regressão espontânea - Os casos de cisto ósseo traumático quase nunca foram encontrados em mandíbulas de adultos com mais de 30 anos. Uma óbvia dedução destes achados foi o fato desta lesão não ser apenas alto-limitante, mas capaz de remissão completa e espontânea. Possivelmente, uma hemorragia ocorreria dentro da lesão, tendo o mesmo efeito da intervenção cirúrgica. Entretanto, a cavidade somente seria completamente preenchida com sangue se estivesse totalmente vazia, quando a hemorragia espontânea ocorresse.

O estudo da provável etiologia do cisto ósseo traumático nos 17 casos descritos por ZEGARELLI et al. ${ }^{132}$, em 1966, mostrou que esta doença não apresenta evidências de envolvimento familial, nem doença ou anormalidade sistêmica. Dos 17 pacientes, seis apresentavam história de algum tipo de trauma na mandíbula ou na face. Porém os autores ${ }^{132}$ concluíram que, raramente, a criança não apresentava experiência de alguma forma de trauma.

Em uma série de 66 casos relatados por HANSEN et al..$^{43}$, em 1974, a história de trauma estava presente na maioria dos pacientes. Acrescentaram que esta relação foi estatisticamente válida, mas não compararam estes achados com os de pacientes que apresentavam história de trauma e não exibiam cisto ósseo traumático. 0 trauma poderia ser um fator no desenvolvimento do cisto ósseo traumático, mas questões relativas a modo, intensidade, freqüência e patogênese não foram determinadas. Os autores $^{43}$ enfatizaram a necessidade do relato claro, completo e detalhado dos casos, sendo este o único meio de análise do problema. Concluíram que muitos artigos têm sido publicados sobre este assunto, mas nenhum progresso ocorreu para explicar as causas e progressão da doença, sendo os trabalhos baseados em revisões prévias das teorias da etiologia e patogênese, podendo esta lesão continuar a existir indefinidamente como uma entidade inexplicável, ou se pesquisas futuras não elucidarem a sua etiopatogenia. 
MELROSE et al. ${ }^{74}$, em 1976, observaram que as biópsias dos pacientes com displasia óssea florida, associada ou não ao cisto ósseo traumático, freqüentemente mostravam numerosos capilares dilatados. Os autores ${ }^{74}$ especularam que a produção desordenada de osso resultaria na obstrução da drenagem do fluido intersticial, levando àformação do cisto. $O$ desenvolvimento de cistos múltiplos e a falha à resposta terapêutica poderiam sugerir que os casos de cisto ósseo traumático, associados à displasia óssea florida representariam uma etiopatogenia única, distintos dos casos comuns.

A etiologia do cisto ósseo traumático foi relacionada aos achados microscópicos, por BEASLEY5, em 1976. A maioria das mudanças microscópicas observadas em 30 casos tendeu a suportar a característica de um processo degenerativo, mostrando mudanças nos espaços trabeculares antes da formação da cavitação e lise óssea. As mudanças fibromixomatosas estavam intimamente associadas à perda de estrutura óssea dentro de muitos espaços trabeculares. A destruição óssea não estava aparentemente associada à reabsorção osteoclástica ativa. 0 autor ${ }^{5}$ defendeu a teoria da degeneração fibromixomatosa de origem primária desconhecida.

Após o relato de um caso clínico de cisto ósseo aneurismático tratado cirurgicamente e recorrendo como um cisto ósseo traumático, HILLERUP; HJORTING-HANSEN50, em 1978, consideraram a possibilidade do cisto ósseo aneurismático, do cisto ósseo traumático e do granuloma central de células gigantes serem diferentes expressões da mesma doença ou falhas no processo de cura de lesões ósseas. Os autores ${ }^{50}$ sugeriram que estas três lesões teriam uma etiologia vascular e que os fatores ambientais locais dentro do osso, poderiam diferenciar a patogênese, como a seguir: 
$\Rightarrow 0$ cisto ósseo aneurismático, o cisto ósseo traumático e o granuloma central de células gigantes se originariam da mesma lesão ou defeito ósseo.

$\Rightarrow$ Um trauma mínimo ou a presença de um pequeno alargamento aneurismal não identificado poderia resultar em um sangramento intramedular, levando àformação de um hematoma.

$\Rightarrow$ Quando o hematoma resultante estivesse em conecção circulatória direta com 0 feixe principal da mandíbula, uma pressão sangüínea ou contínua ou pulsátil poderia expandir o osso, e o cisto ósseo aneurismático ser formado.

$\Rightarrow$ Quando apenas vasos menores estivessem relacionados ao hematoma, 0 processo de tentativa de reparo levaria à proliferação endotelial e formação de grande quantidade de células gigantes, podendo resultar na formação do granuloma central de células gigantes.

$\Rightarrow$ Quando o suprimento vascular da circulação fosse bloqueado, coincidindo com a presença de grandes espaços medulares e uma baixa densidade de osso esponjoso da mandíbula, o osso compacto delimitaria o hematoma irregularmente, formando o cisto ósseo traumático.

Uma sugestão foi feita por HOSSEIN|51, em 1978/1979, propondo que o cisto ósseo traumático pudesse resultar de uma diferenciação anormal das células mesenquimais, havendo falha da osteogênese e conseqüente formação de um hamartoma sinovial. $O$ cisto ósseo traumático poderia, assim, originar-se a partir de múltiplas cavidades sinoviais, posteriormente coalescendo para formar um grande defeito ósseo revestido por tecido conjuntivo. Esta hipótese poderia explicar a formação dos contornos irregulares, bem como a idade e local de aparecimento da lesão.

DAVIS et al. ${ }^{23}$, em 1979, teorizaram os eventos que levam ao desenvolvimento, curso e resolução do cisto ósseo traumático. Uma anormalidade 
vascular produziria pressão dentro do osso medular, levando à reabsorção óssea e formação de uma lesão, a qual teria entrada e saída para o fluxo sangüíneo. Gradualmente o fluxo sangüíneo diminuiria, causando a formação de um fluido seroso e coágulo sangüíneo dentro da lesão. Este material, lentamente reabsorvido, formaria um defeito ósseo vazio, podendo ocorrer deposição óssea após um período de tempo.

COWAN ${ }^{18}$, em 1980, relatou a possibilidade do cisto ósseo traumático dos maxilares apresentar uma etiopatogenia variável, fornecendo características clínicas diversificadas. Segundo $\operatorname{COWAN}^{18}$, o cisto pode apresentar-se como duas lesões diferentes, o típico cisto ósseo traumático e o raro cisto unicameral dos ossos longos, presente nos maxilares.

O extenso estudo de KAUGARS; CALE ${ }^{61}$, em 1987, mostrou que a incidência de trauma em pacientes com cisto ósseo traumático foi equivalente àquela observada na população em geral. Os autores ${ }^{61}$ também enfatizaram o diferente comportamento biológico quando este cisto ocorria em pessoas mais idosas, especialmente em mulheres da raça negra, com lesões múltiplas, associadas àdisplasia óssea florida e recorrências da lesão.

HIGUCHI et al. ${ }^{49}$, em 1988, relataram quatro casos de displasia cementóssea associadas ao cisto ósseo traumático, todos ocorrendo em mulheres com mais de 30 anos de idade. Para os autores ${ }^{49}$ a mudança cística ocorreu após 0 desenvolvimento da displasia cementóssea, sugerido por imagens radiográficas, devido à preexistência da displasia e íntima relação topográfica entre esta e a formação do cisto em todos os casos. 
Similar ao trabalho de HILLERUP; HJORTING-HANSEN 50 , os quais traçaram um paralelo entre o cisto ósseo aneurismático, o cisto ósseo traumático e o granuloma central de células gigantes, STIMSOM; MCDANIEL ${ }^{115}$, em 1989, compararam os aspectos clínicos, radiográficos e microscópicos destas três lesões ósseas. Os autores sugeriram que, embora estas lesões sejam reconhecidas como entidades patológicas distintas e separadas, uma patogênese comum pode existir pelas similaridades de certas características tais como:

$\Rightarrow$ todas as três lesões são mais freqüentes na primeira e segunda década de vida;

$\Rightarrow$ a mandíbula constitui o sítio mais comum de ocorrência ;

$\Rightarrow$ um número significante de pacientes com cisto ósseo aneurismático e cisto ósseo traumático relatam história de trauma;

$\Rightarrow$ características microscópicas similares entre o cisto ósseo aneurismático e 0 granuloma central de células gigantes;

$\Rightarrow$ a associação do cisto ósseo aneurismático e do cisto ósseo traumático a outras lesões ósseas.

Dois casos clinicamente bem documentados, radiograficamente compatíveis com cisto ósseo traumático da mandíbula, relatados por SAPP; STARK ${ }^{107}$, em 1990, tiveram aparente cura sem intervenção cirúrgica, fornecendo informações adicionais ao entendimento da sua natureza biológica. A alta incidência desta lesão em jovens, sugere uma capacidade de regressão espontânea. Se esta lesão não fosse capaz de curar espontaneamente, muito mais casos seriam encontrados em adultos e em tamanhos maiores. Ainda, se este cisto é mais comum no período de crescimento ósseo ativo, este fator deve ser seriamente considerado e integrado em alguma teoria da patogênese do cisto ósseo traumático. SAPP; STARK ${ }^{107}$ em desacordo à teoria do hematoma intra-ósseo pós-traumático, questionaram a ausência de uma alta incidência de cisto ósseo traumático em atletas profissionais, tais como jogadores de futebol, 
boxeadores, os quais recebem um grande número de golpes nos maxilares. Porém, tal afirmação não foi confirmada.

SHEAR ${ }^{112}$, em 1992, argumenta contra a teoria de OLECH ${ }^{86}$ et al., particularmente devido ao fato das dificuldades em se estabelecer uma história de trauma, apesar de, em alguns casos o trauma poder ser o fator iniciador. $O$ autor alega a possibilidade de algum outro estímulo levar àruptura das finas paredes dos sinusóides e ocorrer uma hemorragia intramedular.

Após o estudo clínico e histopatológico de 19 casos, classificados em dois grupos, um jovem (menor de 30 anos) e um adulto (maior de 31 anos), SAITO et al. ${ }^{106}$, em 1992, concluíram que o cisto ósseo traumático poderia ser um grupo heterogêneo de lesões com diferentes causas, devido ঝ̀s diferenças no comportamento biológico apresentando pelos dois grupos. No grupo de pacientes jovens, os cistos foram típicos, semelhantes àqueles relatados na literatura. No grupo adulto, os cistos foram atípicos, predominante em pacientes do sexo feminino e comumente associados a lesões radiopacas. Os autores chamam a atenção para o provável fator hormonal na patogênese das lesões radiopacas associadas a estes cistos. Seguindo a mesma linha de raciocínio, MACDONALD-JANKOWSKI71, em 1995, também classificou 20 casos de cisto ósseo traumático em dois grupos, tendo o grupo jovem de ambos os sexos, apresentado lesões típicas, e o grupo adulto só do sexo feminino, apresentado lesões múltiplas e recidivantes, apenas no sexo feminino.

A análise bioquímica de fluido do cisto ósseo traumático realizada por DONKOR; PUNNIA-MOORTHY25, em 1994, demonstrou a similaridade do fluido cístico com o soro humano, significando assim que este fluido originou do sangue 
por algum mecanismo desconhecido, levando os autores ${ }^{25}$ a defenderem a teoria do extravasamento.

Trabalhos mais atuais como os de BREEN; ADDANTE ${ }^{14}$, em 1994, LUDWIG; MERTEN70 e MACDONALD-JANKOWSKI ${ }^{71}$, em 1995, e TANAKA et al. ${ }^{118}$, em 1996, insistem na hipótese de que a etiopatogenia do cisto ósseo traumático, permanece ainda desconhecida, necessitando mais trabalhos para definir a verdadeira teoria.

A Tabela 2.2 mostra, em ordem cronológica, as principais teorias referentes àetiopatogenia do cisto ósseo traumático.

TABELA 2.2 - Distribuição das principais teorias e seus autores, referentes à etiopatogenia do cisto ósseo traumático

\begin{tabular}{|c|c|}
\hline Autores / ano & Etiopatogenia \\
\hline LUCAS $^{11}$, em 1929 & Teoria traumático-hemorrágica \\
\hline JAFFE; LICHTENSTEIN59, em 1942 & $\begin{array}{c}\text { Teoria do distúrbio local do crescimento e } \\
\text { desenvolvimento ósseo }\end{array}$ \\
\hline OLECH et al. ${ }^{86}$, em 1951 & Teoria da hemorragia intramedular \\
\hline MELROSE et al. ${ }^{74}$, em 1976 & $\begin{array}{l}\text { Teoria da obstrução da drenagem do fluido } \\
\text { intersticial }\end{array}$ \\
\hline BEASLEY $^{5}$, em 1976 & Teoria da degeneração fibromixomatosa \\
\hline $\begin{array}{c}\text { HILLERUP; HJORTING-HANSEN50, } \\
\text { em } 1978\end{array}$ & $\begin{array}{c}\text { Teoria da etiologia da alteração vascular, } \\
\text { relacionadas ao cisto ósseo aneurismático, cisto } \\
\text { ósseo traumático e granuloma central de células } \\
\text { gigante }\end{array}$ \\
\hline HOSSEINI51, em 1978/1979 & $\begin{array}{c}\text { Teoria da diferenciação anormal das células } \\
\text { mesenquimais }\end{array}$ \\
\hline
\end{tabular}




\begin{tabular}{c|c}
\hline DAVIS et al. ${ }^{23}$, em 1979 & Teoria da anormalidade vascular \\
\hline SAITO et al. ${ }^{106}$, em 1992 & Teoria do grupo heterogêneo de lesões com \\
& diferentes causas \\
\hline \hline
\end{tabular}

\subsection{Aspectos clínicos e radiográficos}

O primeiro caso clínico de cisto ósseo traumático descrito na literatura ocorreu em um paciente de 12 anos de idade, envolvendo os molares inferiores com vitalidade pulpar, a lesão era radicada somente em osso medular ${ }^{11}$. Posteriormente, três casos clínicos de cisto ósseo traumático foram descritos, em pacientes jovens (um de 14 e dois de 17 anos), todos assintomáticos, encontrados em exame radiográfico de rotina. As lesões localizavam-se na mandíbula, na região de pré-molares e molares com vitalidade pulpar. Os pacientes relataram história de trauma e ausência de antecedente familial e história médica ausente, não sendo também, encontradas lesões em outros ossos do corpo. $O$ aspecto radiográfico dos três cistos era de uma imagem radiolúcida, bem circunscrita, mas com ausência de uma linha esclerótica delimitante, ao contrário do que ocorria nos cistos radicular e folicular ${ }^{10}$. 
Em 1951, um estudo crítico e completo da literatura realizado por OLECH et al ${ }^{86}$, revisou 20 casos anteriormente descritos e relatou oito novos casos. A cuidadosa avaliação dos sintomas e história dos casos relatados pelos autores ${ }^{86} \mathrm{e}$ daqueles revisados na literatura, mostraram que um número significativo de sinais tem estado presente nos casos diagnosticados como cisto ósseo traumático. Para que 0 diagnóstico seja dado com um razoável grau de confiabilidade, estas características foram enumeradas:

\section{Sinais $\underline{\text { e Sintomas clínicos (pré-operatórios) }}$}

$\Rightarrow$ nenhuma história de dor ou outro sintoma subjetivo foi relatada pelo paciente;

$\Rightarrow 0$ cisto foi descoberto incidentemente, em exame radiográfico de rotina;

$\Rightarrow$ a cavidade era unilocular e completamente envolvida por osso;

$\Rightarrow$ não havia alargamento ósseo palpável;

$\Rightarrow$ a cavidade cística não se comunicava com a cavidade bucal;

$\Rightarrow$ os dentes da área envolvida apresentavam vitalidade pulpar;

$\Rightarrow$ os cistos foram encontrados em indivíduos jovens;

$\Rightarrow$ na maioria dos casos havia história de trauma;

\section{Achados operatórios}

$\Rightarrow$ uma área preto-azulada que cobria a lesão era usualmente visível por reflexão dos tecidos moles antes de se obter a entrada da cavidade;

$\Rightarrow$ a cavidade continha fluido seroso-hemorrágico ou estava vazia;

$\Rightarrow$ nenhuma membrana de revestimento era clinicamente visivel;

\section{Achados microscópicos}

$\Rightarrow$ epitélio não foi encontrado no exame microscópico;

$\Rightarrow$ a cortical óssea removida durante a cirurgia mostrava sinais de reabsorção; 


\section{Aspectos terapêuticos}

$\Rightarrow$ exposição da cavidade cística, preenchimento de um novo coágulo sangüíneo, e reposicionamento do retalho de tecido conjuntivo reativo com o novo coágulo formado, levando rapidamente ao reparo, 6 a 12 meses após o ato cirúrgico.

Durante o simpósio realizado em 1955, WHINERY130 relatou três casos de cisto ósseo traumático. Os pacientes foram referidos pelos seus ortodontistas para avaliação de uma lesão descoberta em exame radiográfico, em dois casos durante 0 tratamento ortodôntico e, em um caso, em exames prévios ao tratamento. Todos os casos ocorreram em pacientes jovens (7 e 12 anos de idade), assintomáticos, no corpo mandibular e os dentes da região apresentavam vitalidade pulpar. Em apenas um caso havia história de trauma, mas não na região afetada pelo cisto. A história médica dos três pacientes era negativa e os exames de cálcio sérico e fosfatase alcalina estavam dentro dos limites normais. Radiograficamente as lesões eram radiolúcidas. Em dois casos eram bem delimitadas com presença das margens crenadas e em um caso, a área radiolúcida era irregular, com má-definição de seus contornos.

Vinte casos clínicos de cisto ósseo traumático foram investigados por GARDNER et al. ${ }^{37}$, em 1962. A história clínica, a localização, a idade, o sexo, os aspectos radiográficos, microscópicos e o tratamento foram avaliados. 0 cisto ósseo traumático ocorreu principalmente em pacientes jovens do sexo masculino, com uma média de 18 anos. A lesão era usualmente descoberta em exame radiográfico de rotina, estando os sintomas clínicos geralmente ausentes. A região de molares e prémolares da mandíbula era o principal sítio da lesão, com a maioria dos dentes adjacentes ao cisto vitais. $O$ trauma pareceu ser o principal fator etiológico, embora isto não pudesse ser confirmado por uma história adequada. O diagnóstico pré-operatório foi de cisto ósseo 
traumático na grande maioria dos casos, sendo incorretamente diagnosticado como tumor de células gigantes, ameloblastoma e cisto radicular, em quatro casos.

Durante um período de 20 anos, em uma população clínica de 60.000 pacientes, apenas 17 casos de cisto ósseo traumático foram conclusivamente documentados por ZEGARELLI et al.132, até 1966. Dos 17 casos documentados, 8 ocorreram em homens e 9 em mulheres, 10 pacientes tinham entre 5 a 15 anos de idade, 5 pacientes entre 15 e 25 anos, e 2 pacientes mais de 26 anos de idade. Dezesseis casos foram encontrados em exame radiográfico de rotina, e 15 pacientes não apresentavam nenhuma anormalidade clínica. Apenas dois queixavam-se de vaga dor na região da lesão, com uma pequena deformidade da cortical óssea. Em todos os pacientes os dentes na região da lesão estavam em posição e cor normal com vitalidade pulpar. Com relação aos aspectos radiográficos, todos os cistos estavam localizados na mandíbula, 8 na região anterior e 9 na posterior. Expansão mínima da cortical óssea foi observada em 3 casos. Quinze pacientes apresentavam imagens radiolúcidas única e duas múltiplas. Medidas realizadas diretamente nas radiografias determinaram que a dimensão destas imagens variavam de $0,8 \mathrm{~cm}$ a $4,2 \mathrm{~cm}$. As lesões mostravam imagens diferentes, seis eram redondas e elípticas e nove lobuladas. Uma borda hiperostótica estava freqüentemente presente, mas contornava apenas parcialmente, a imagem transparente. Treze casos estavam situados periapicalmente, mas não havia evidência de reabsorção radicular atribuída àação da lesão.

O uso da radiografia panorâmica, para determinar o nível de saúde bucal, a necessidade de tratamento e a incidência de certas entidades, proporcionou o diagnóstico de 22 casos de cisto ósseo traumático, relatados por MORRIS, et al. ${ }^{79}$, em 1970. Todos os casos ocorreram na mandíbula, não atingindo côndilo ou processo coronóide, sendo assintomáticos, com $25 \%$ de resposta positiva ao 
trauma e em pacientes na $2^{a}$ e $3^{a}$ décadas de vida. Expansão mínima da cortical óssea vestibular da mandíbula foi observada em seis casos. Apenas em um caso a vitalidade pulpar dos dentes envolvidos, foi negativa. As lesões apresentaram-se radiolúcidas, de bordas bem definidas na grande maioria, embora só quatro tivessem bordas escleróticas. A lâmina dura estava preservada na quase totalidade dos casos, em nenhum caso ocorreu reabsorção ou divergência radicular e em seis casos os contornos crenados das bordas foram notados. Porém, o aspecto radiográfico dos 22 casos foi bem diversificado, não fornecendo um diagnóstico seguro.

A revisão da literatura desde 1929, realizada por HUEBNER; TURLINGTON54, em 1971, revelou a existência de 150 casos de cisto ósseo traumático. Nesta revisão, os critérios propostos por RUSHTON ${ }^{104}$, com algumas modificações, foram usados para a seleção dos casos, e os aspectos, assim descritos:

\section{Aspectos clínicos $\underline{\text { e radiográficos }}$}

$\Rightarrow$ Idade média: 19,72 anos. A maioria dos pacientes estava na segunda década, embora, 14 pacientes tinham mais de 35 anos;

$\Rightarrow$ Sexo: $60 \%$ eram do sexo masculino, $37 \%$ do sexo feminino e $4 \%$ não foi relatado;

$\Rightarrow$ Sítio da lesão: $71,83 \%$ ocorreram na região posterior da mandíbula $(41,74 \%$ à direita e $30,09 \%$ à esquerda), $24,27 \%$ na região anterior e 2,9\% ocorreram na maxila;

$\Rightarrow$ Sintomas: $61 \%$ estavam assintomáticos e as lesões foram diagnosticadas no exame radiográfico de rotina, $24 \%$ tinham tumefação, $18 \%$ dor, $4 \%$ tinham supuração na cavidade bucal e 3\% alguma forma de parestesia;

$\Rightarrow$ Expansão da cortical óssea: detectada clinicamente em 52 pacientes;

$\Rightarrow$ Vitalidade dos dentes: 89 dos 150 pacientes tinham os dentes relacionados ao cisto, vitais. Porém, os dentes não vitais estavam relacionados à cárie ou trauma prévio; 
$\Rightarrow$ Deslocamento dentário: ocorreu em apenas 9 pacientes;

$\Rightarrow$ Lesão múltipla: bilateralidade ocorreu em 4 casos.

Um estudo de 66 casos de cisto ósseo traumático, previamente não descritos, foi relatado por HANSEN et al. ${ }^{43}$, em 1974. Para que as lesões fossem aceitas como cisto ósseo traumático e incluídas neste trabalho, os seguintes critérios foram usados: (1) Na operação, a cavidade deveria apresentar-se essencialmente vazia, ou ocasionalmente, com algum fluido e/ou pequena quantidade de tecido mole. (2) Os achados clínicos, radiográficos e microscópicos não deveriam excluir o diagnóstico de cisto ósseo traumático. Os aspectos analisados abrangeram idade, sexo, sintomas, expansão das corticais ósseas, vitalidade dos dentes, achados operatórios, achados radiográficos, localização da lesão, diagnóstico microscópico e história de trauma. Por meio da análise dos dados, os resultados obtidos demonstraram:

$\Rightarrow$ a maioria dos casos ocorreu em pacientes com idade entre 11 e 20 anos;

$\Rightarrow$ não houve diferença significante entre os sexos;

$\Rightarrow$ os cistos eram, na maior parte, assintomáticos descobertos no exame de rotina, embora alguns sintomas, geralmente vagos e inespecíficos, poderiam estar presentes;

$\Rightarrow$ a expansão das corticais ósseas foi rara, ocorrendo em apenas 14 pacientes e sendo questionável em oito destes casos;

$\Rightarrow$ os dentes adjacentes eram usualmente vitais;

$\Rightarrow$ a cavidade era essencialmente vazia;

$\Rightarrow$ os aspectos radiográficos foram consideravelmente variáveis. Todas as lesões mostraram vários graus de radiolucência, tamanho, forma e definição. Em alguns casos 0 aspecto foi sugestivo, sendo a exploração cirúrgica essencial para 0 diagnóstico definitivo; 
$\Rightarrow$ o sítio de localização mais comum foi a mandíbula (45 casos), porém as lesões ocorreram na maxila (21 casos), mais freqüentemente que previamente relatado. Nenhum paciente tinha lesão múltipla;

$\Rightarrow$ a história de trauma estava presente em mais de $50 \%$ dos casos;

$\Rightarrow 0$ cisto ósseo traumático não foi tão raro como previamente relatado.

Trinta casos de cisto ósseo traumático dos maxilares foram apresentados por BEASLEY5, em 1976, com detalhes clínico e microscópico. As lesões ocorreram mais freqüentemente na segunda década de vida, embora a idade tenha variado de 12 a 57 anos. Homens mostraram uma incidência (61,5\%) levemente mais alta que as mulheres. A maioria dos cistos ocorreu na região posterior da mandíbula $(76,9 \%)$, dois casos foram observados na maxila, sendo um caso bilateral. História positiva de trauma pôde ser obtida em apenas sete casos. Seis pacientes apresentaram sintomas, e estes incluíam sensibilidade dentária, dor leve irradiada e hipersensibilidade dentária à percussão. Em todos os pacientes, nos quais o teste de vitalidade pulpar foi realizado, os resultados indicaram positividade. A aparência radiográfica variou de uma área radiolúcida multilocular a uma área solitária de destruição óssea. Vários casos demonstraram a presença dos contornos crenados relacionado aos dentes envolvidos. Em apenas um caso a expansão da cortical óssea foi notada, e em outro a erosão da cortical foi observada cirurgicamente. Os cistos foram detectados em exames radiográficos de rotina.

MELROSE et al. ${ }^{74}$, em 1976, descreveram 17 casos de cisto ósseo traumático associados à displasia óssea florida, afetando 14 pacientes. Todos os pacientes eram mulheres negras, assintomáticas, com idade média de 42 anos. Uma paciente desenvolveu cistos mandibulares bilaterais e uma na maxila posterior, e um segundo paciente apenas cistos mandibulares bilaterais. Os cistos concomitantes eram 
bem definidos radiograficamente, tendo em três casos o tecido mineralizado preso ao ápice radicular, projetando-se para dentro da cavidade radiolúcida. Os cistos variaram de 0,5 a 3,5cm na maior dimensão, exceto em um caso em que toda a mandíbula foi progressivamente escavada. Quatro cistos foram encontrados em áreas desdentadas e três foram localizados entre as raízes dos molares mandibulares. As pequenas lesões eram bem demarcadas e uniloculares. Os cistos maiores tenderam a ser multiloculares, sugerindo lesões odontogênicas ou lesões fibrósseas, e estavam associados à expansão óssea em quatro casos. $O$ fato de todos os cistos aparecerem em pacientes adultos e associados à displasia óssea florida, formando um padrão atípico, divergiu de estudos clássicos $5,37,43,54,79,86,132$. Os autores ${ }^{74}$ concluíram que houve uma alta incidência incomum de cistos ósseo traumático em pacientes com displasia óssea florida comparada a pacientes da mesma idade sem a displasia.

Um total de 161 casos de cisto ósseo traumático, 94 de revisão da literatura e 67 casos, previamente não relatados, foram analisados por KAUGARS; CALE 61 , em 1987, baseados em características clínicas e microscópicas. Para serem considerados aceitáveis, os casos clínicos relatados deveriam satisfazer aos seguintes critérios: (1) Descrição cirúrgica de cavidade óssea vazia, com um fino revestimento de tecido mole e/ou contendo fluido. (2) Fotomicrografias ou a descrição microscópica, mostrando o espécime cirúrgico composto de tecido conjuntivo fibroso e/ou osso viável e não sugestivo de outro diagnóstico. Os casos analisados por KAUGARS; CALE ${ }^{61}$ mostraram os seguintes resultados:

$\Rightarrow$ Sexo, idade e raça : não houve predileção por sexo. A maioria dos pacientes tinha menos de 20 anos, mas $27 \%$ estavam acima dos 30 anos, abrangendo principalmente mulheres da raça negra, embora o cisto mostrasse maior incidência em paciente jovens brancos; 
$\Rightarrow$ Localização anatômica: Quase todos os casos ocorreram na mandíbula (acima de 94\%) com predileção pela porção posterior (72\%), postulando que a rara ocorrência da lesão na maxila pode ser explicada por sua relativamente pequena quantidade de osso medular e da vascularidade. A bilateralidade do cisto estava presente em $20,3 \%$ dos casos novos e em $18,9 \%$ dos casos revisados;

$\Rightarrow$ Vitalidade pulpar, história de trauma e sintomatologia: a vitalidade pulpar foi positiva em $92,9 \%$ dos casos novos e $83,9 \%$ dos anteriormente relatados. Com relação à história de trauma e sintomatologia, uma discrepância foi observada entre os dois grupos. A história de trauma foi confirmada em $35,3 \%$ dos casos novos e $72,3 \%$ dos casos da literatura. $25,6 \%$ dos casos novos e $59,6 \%$ descritos anteriormente apresentaram sintomas. A incidência de trauma foi equivalente àquela notada na população em geral.

$\Rightarrow$ Lesões múltiplas e recorrência: lesões múltiplas ocorreram em 10,7\% dos casos revisados na literatura, sendo estas lesões mais comuns em mulheres negras. Recorrência foi documentada em seis casos durante a revisão da literatura, com ocorrência maior no sexo feminino, em lesões múltiplas, ou em pacientes que apresentaram uma descoloração azulada do osso, aparentemente causada pela erosão da cortical óssea, permitindo ao fluido intra-ósseo tornar-se clinicamente visível.

$\Rightarrow$ Associação com a displasia óssea florida: esta associação foi reforçada devido a uma alta incidência do cisto ósseo traumático em mulheres negras, entre os pacientes com mais de 30 anos de idade.

Um estudo de 23 cistos ósseos traumáticos incluindo análise das características clínicas, radiográficas, microscópicas, tratamento e controle, foi realizado por FORSSELL et al. ${ }^{31}$, em 1988. Os aspectos analisados mostraram os seguintes resultados: 


\section{Aspectos clínicos}

$\Rightarrow$ Os 23 cistos foram encontrados em 22 pacientes, 9 mulheres e 13 homens, com maior incidência na segunda década. Os únicos sintomas causados pelos cistos foram dor em cinco casos, tumefação em um e fístula em um caso. A vitalidade pulpar foi positiva em todos os dentes adjacentes aos cistos, mantendo-se vitais nos controles. História de trauma facial foi relatada em quatro pacientes.

\section{Aspectos radiográficos}

$\Rightarrow$ Todos os cistos localizaram-se na mandíbula, seis na região anterior, 13 na área de pré-molares e quatro na região de ângulo e ramo. A aparência radiográfica foi unilocular com contornos crenados em 16 casos e com contornos ondulados em cinco casos, sendo que dois cistos eram multiloculares. O diâmetro dos cistos variaram de 12 a $70 \mathrm{~mm}$, com média de $31 \mathrm{~mm}$. As bordas das lesões foram bem definidas em 10 casos e parcialmente definidas e parcialmente difusas em 11 casos. Todos os casos com bordas bem definidas eram delineados por uma fina linha radiopaca. $O$ adelgaçamento da cortical óssea foi observado em 11 cistos, mas a expansão óssea ocorreu em apenas um caso. Os contornos crenados dos cistos entre as raízes dentárias foram observados em 10 casos, e divergência dos dentes adjacentes em cinco casos. A lâmina dura dos dentes estava totalmente ou parcialmente destruída em 12 casos e em dois casos observou-se reabsorção radicular. Na maioria dos casos, o diagnóstico presuntivo do cisto ósseo traumático pôde facilmente ser sugerido, baseado nos achados radiográficos. Apenas duas lesões multiloculares causaram dificuldades no diagnóstico pré-operatório.

Dois casos de cisto ósseo traumático que tiveram cura espontânea, relatados por SAPP; STARK ${ }^{107}$, em 1990, tiveram seu diagnóstico confirmado, baseado em critérios clínicos e radiográficos.

\section{Critérios clínicos}


1. Não havia história de dor ou outra sensação na área;

2. Os dentes da área envolvida eram vitais;

3. Não havia comunicação com a cavidade bucal;

4. As lesões ocorreram, principalmente, na segunda e terceira década.

\section{Critérios radiográficos}

1. As lesões eram bem circunscritas e dentro da porção medular do osso;

2. As lesões eram radiolúcidas, tendo um contorno curvo regular, mas sem corticação;

3. As formas das lesões variaram de redonda a oval, freqüentemente com uma borda crenada, estendendo-se por entre as raízes dos dentes. A lâmina dura foi, usualmente encontrada intacta em torno de todos os ápices radiculares, estendendo para dentro da radiolucência;

4. As lesões æ̇̀ vezes adelgaçavam e/ou expandiam as corticais.

SAITO et al.106, em 1992, selecionaram, para estudo, 19 cistos ósseos traumáticos em um arquivo de 1.283 cistos dos maxilares (incidência de 1,2\%), diagnosticados com base nos aspectos clínicos, radiográficos, cirúrgicos e microscópicos. Estes cistos foram classificados em dois grupos, 11 cistos afetando 10 pacientes com menos de 30 anos de idade (grupo jovem) e oito cistos afetando cinco pacientes com mais de 31 anos de idade (grupo idoso). A comparação dos cistos nos dois grupos revelou: 


\begin{tabular}{|l|c|c|}
\hline \hline Aspectos clínicos e radiográficos & $\begin{array}{c}\text { Grupo jovem } \\
\text { (10 pacientes/11 cistos) }\end{array}$ & $\begin{array}{c}\text { Grupo idoso } \\
\text { (5 pacientes/8 cistos) }\end{array}$ \\
\hline \hline Idade média & 17 anos (12-29) & 42 anos (38-48) \\
\hline Sexo (M/F) & $7: 3$ & $1: 4$ \\
\hline Localização (maxila/mandíbula) & $0: 11$ & $2: 6$ \\
\hline Casos de cistos múltiplos & $1 / 10$ & $3 / 5$ \\
\hline Cistos com lesões radiopacas & $0 / 11$ & $5 / 8$ \\
\hline Cistos com perda da lâmina dura & $1 / 7$ & $5 / 6$ \\
\hline $\begin{array}{l}\text { Cistos com exposição dos dentes } \\
\text { durante a cirurgia }\end{array}$ & $0 / 11$ & $3 / 6$ \\
\hline $\begin{array}{l}\text { Cistos com hipercementose ou } \\
\text { displasia cementária periapical }\end{array}$ & $0 / 11$ & $3 / 6$ \\
\hline
\end{tabular}

Fonte: SAITO et al. ${ }^{106}$, em 1992.

Com relação à freqüência do cisto ósseo traumático, SHEAR ${ }^{112}$, em 1992, relatou que este cisto não era uma lesão comum, tendo encontrado apenas 26 espécimes em seu Departamento, durante um período de 32 anos, perfazendo um total de $1 \%$ dos cistos dos maxilares. 0 autor acrescentou que outros casos foram tratados em seu hospital, porém, nenhum conteúdo foi encontrado para exame microscópico.

Uma série de 20 casos de cisto ósseo traumático, em 14 pacientes chineses foi estudada por MACDONALD-JANKOWSKI71, em 1995. Dos 20 cistos, 19 ocorreram na mandíbula e um na maxila. Os 14 pacientes (cinco homens e nove mulheres) foram divididos em dois grupos, segundo sexo e idade. 0 grupo jovem era de ambos os sexos e o grupo idoso, exclusivamente do sexo feminino. 0 diagnóstico 
definitivo de cisto ósseo traumático foi dado pelo ato cirúrgico, antecipado por radiografias pré-operatórias. Quinze cistos foram encontrados em nove mulheres e cinco cistos em cinco homens. A diferença na média de idade entre os dois sexos foi estatisticamente significante, com 19,8 para o masculino e 40,6 para o feminino. Com exceção de três pacientes, todos estavam livres de sintomas, sendo diagnosticados em radiografias de rotina. Radiograficamente os cistos apareceram como radiotransparências uniloculares de forma oval, bem definidas, apresentando as margens crenadas ("scalloping") em seis casos. Deslocamento e reabsorção dentária não foram encontrados. Medidas da área das lesões foram realizadas em imagens digitais, observando-se lesões maiores em pacientes jovens e menores em pacientes idosos, ocorrência justificada pela regressão da lesão com o passar dos anos. Como todas as recorrências e lesões múltiplas ocorreram no grupo idoso, 0 autor ${ }^{71}$ afirmou haver uma associação entre multiplicidade do cisto, recorrência, sexo feminino e idade mais avançada, sugerindo acompanhamento radiográfico periódico, especialmente neste grupo de pacientes.

As novas técnicas de diagnóstico por imagem, tais como a tomografia computadorizada e a ressonância magnética foram, recentemente, empregadas como auxiliar no diagnóstico do cisto ósseo traumático, especialmente nos casos atípicos. Em 1994, SHIGEMATSU et al. ${ }^{113}$ relataram um caso de cisto ósseo traumático, atingindo ramo e côndilo da mandíbula. $\mathrm{O}$ uso da tomografia computadorizada revelou tumefação das corticais ósseas vestibular e lingual e uma erosão de baixa densidade, similar a cisto. Ainda em 1994, SUEl et al. ${ }^{116}$ examinaram radiografias panorâmicas e tomografias computadorizadas de pacientes com cisto ósseo traumático e de um modelo experimental, com o objetivo de avaliar a presença ou não de gás na cavidade cística. Os autores ${ }^{116}$ concluíram que o conteúdo da cavidade não coincidia com a densidade do gás na tomografia computadorizada, indicando que os achados operatórios de ar nos cistos ósseos traumáticos têm sido um erro, pelo menos em alguns 
casos. O uso da ressonância magnética no diagnóstico do cisto ósseo traumático, relatado por TANAKA et al. ${ }^{118}$, em 1996, fala a favor dos achados de SUEI et al..116, indicando ser 0 fluido o conteúdo mais provável da cavidade, sendo o gás improvável, devido àintensidade dos sinais encontrados.

A Tabela 2.3 apresenta os principais trabalhos epidemiológicos, com as maiores casuísticas de cisto ósseo traumático, descrevendo seus autores e ano de publicação.

TABELA 2.3 - Distribuição das maiores casuísticas de cisto ósseo traumático relatados na literatura, em relação aos autores e ano

\begin{tabular}{|c|c|}
\hline Autores/ano & № de casos \\
\hline "GARDNER et al. ${ }^{37}$, em 1962 & 20 \\
\hline ZEGARELLI et al. ${ }^{132}$, em 1966 & 17 \\
\hline MORRIS et al..$^{79}$, em 1970 & 22 \\
\hline HANSEN et al. ${ }^{43}$, em 1974 & 66 \\
\hline BEASLEY $^{5}$, em 1976 & 30 \\
\hline MELROSE et al. ${ }^{74}$, em 1976 & 17 \\
\hline KAUGARS; CALE ${ }^{61}$, em 1987 & 67 \\
\hline FORSSELL et al. ${ }^{31}$, em 1988 & 23 \\
\hline SAITO et al. ${ }^{106}$, em 1992 & 19 \\
\hline MACDONALD-JANKOWSKI711, em 1995 & 20 \\
\hline
\end{tabular}




\subsection{Aspectos cirúrgicos, microscópicos e terapêuticos}

A primeira abordagem terapêutica para o cisto ósseo traumático relatada na literatura foi a cirurgia conservadora, sem extração dos dentes vitais presentes na área envolvida pela lesão ${ }^{11}$.

Os três casos clínicos de cisto ósseo traumático descritos por BLUM $^{10}$, em 1932, foram tratados por procedimento cirúrgico, e durante este ato operatório o autor afirmou que: (1) Ele não estava lidando com uma condição ainda desconhecida. (2) O único método de diagnóstico confiável para este cisto era a inspeção cirúrgica e talvez o exame microscópico do espécime. As cavidades encontradas apresentaram-se com pequena quantidade de líquido sangüinolento e sem revestimento por tecido mole observados a olho nu; as raízes dos dentes envolvidos estavam recobertas pelo periodonto, observando-se também formações semelhantes a arco ("archlike") nas paredes da cavidade. O reparo ósseo ocorreu em uma média de seis meses a dois anos após o procedimento e nenhum dente perdeu a vitalidade após a cirurgia. 0 autor ${ }^{10}$ relatou que 0 exame microscópico não era conclusivo, sendo importante apenas quando a inspeção cirúrgica da cavidade fosse sugestiva de outra doença. Os pequenos e poucos fragmentos enviados para exame microscópico revelaram ausência de revestimento epitelial e de células inflamatórias, presença de tecido conjuntivo fibroso bem vascularizado e células sangüíneas, semelhantes ao endósteo. Os fragmentos ósseos removidos mostraram formações sinusóides ou semelhante a arco ("archlike"), áreas de reabsorção osteoclástica e áreas de aposição óssea por osteoblastos. 
Um caso clínico de cisto ósseo traumático, com o diagnóstico presuntivo de ameloblastoma, levando a um tratamento radical de hemimandibulectomia, foi relatado por WALDRON ${ }^{129}$, em 1954. Os aspectos microscópios foram bem descritos, pois cortes seriados de toda a peça foram realizados. A superfície interna da cavidade, cística era revestida por tecido de granulação celular edematoso, contendo muitos eritrócitos e pigmentos de hemossiderina. Na superfície óssea da cavidade observavamse áreas irregulares de reabsorção, notando-se a presença de osteoclastos nas lacunas de Howship e, em outras áreas, osteoblastos e formação de tecido osteóide. 0 autor ${ }^{129}$ concluiu que o estudo microscópico deste caso reforçava a teoria do hematoma intraósseo, sendo a reabsorção óssea o fator principal no alargamento do cisto.

Os três casos clínicos de cisto ósseo traumático relatados por WHINERY ${ }^{130}$, em 1955, foram tratados cirurgicamente. A inspeção cirúrgica revelou cavidade vazia, sem membrana de revestimento, alguns dentes estavam expostos e projetados àcavidade cística, mas sem deslocamento dentário. Em dois casos a cavidade foi fechada após o preenchimento com sangue e em um caso Gelfoam com trombina foram colocados na cavidade, sendo a ferida posteriormente suturada. Os espécimes enviados para o exame microscópico revelaram fragmentos de osso normal, maturo e lamelar, sem revestimento epitelial, distribuição irregular de atividade osteoclástica, contrabalançados por áreas de formação óssea, sem sinal de reação inflamatória.

THOMA ${ }^{122}$, em 1955, apresentou três casos clínicos de cisto ósseo traumático, com a principal finalidade de comparar os antigos métodos de tratamento, com os excelentes resultados obtidos pelo uso de Gelfoam. O procedimento operatório consistiu na evacuação e irrigação da cavidade cística através de uma janela feita intrabucalmente na parede externa do cisto. 0 osso mostrou uma descoloração azulesverdeada. Na cavidade havia algum fluido e tecido de granulação, mas nenhuma 
membrana estava presente. A hemorragia foi contida por meio de epinefrina. Após 0 debridamento, a cavidade foi preenchida com Gelfoam saturado com trombina e penicilina. Após o Gelfoam ter se tornado preenchido com sangue, a ferida foi fechada com sutura. A penicilina foi inserida com a finalidade de prevenir decomposição bacteriana da esponja, e a trombina para prevenir hemorragia secundária. 0 método mostrou excelente resultado, com reparo ósseo completo, cinco meses após a cirurgia.

O tratamento dos vinte casos clínicos de cisto ósseo traumático investigados por GARDNER et al. ${ }^{37}$, em 1962, consistiu na abertura da cavidade óssea, evacuação de algum conteúdo, curetagem para induzir hemorragia e fechamento da ferida cirúrgica. Dois cistos foram tratados com enxerto de osso fresco seco. Um cisto foi tratado com osso autógeno, não obtendo cura. O principal objetivo no tratamento foi criar um novo coágulo sangüíneo em contato com o tecido conjuntivo e osso saudável para que 0 coágulo rapidamente se organizasse e promovesse a cura. A maioria dos cistos continha fluido serossanguinolento. Alguns, tecido mole e outros estavam vazios. $\mathrm{O}$ fato da cavidade estar vazia não foi patognomônico desta lesão. 0 diagnóstico final foi dado pelo patologista, através do exame microscópico somado aos aspectos clínicos, radiográficos e cirúrgico. 0 tratamento foi relativamente simples e o prognóstico excelente após intervenção cirúrgica.

Seguindo o conceito proposto por BLUM ${ }^{9}$, em 1955, de que o cisto ósseo traumático pode regredir sem nenhum tipo de intervenção, SZERLIP117, em 1966, após o diagnóstico clínico e radiográfico de um caso de cisto ósseo traumático bilateral em uma paciente de 15 anos, optou-se pelo acompanhamento periódico da paciente sem nenhum achado cirúrgico ou microscópico. A regressão completa da lesão foi observada após cinco anos. 0 autor ${ }^{117}$ observou que os achados clínicos e radiográficos confirmaram o diagnóstico de cisto ósseo traumático. 
A presença do cisto ósseo traumático foi definitivamente comprovada pela inspeção e intervenção cirúrgica, como relatado por ZEGARELLI et al. ${ }^{132}$, em 1966. Em todos os seus 17 pacientes, o cisto provou ser uma cavidade intraóssea, completamente circundada por osso, sendo este achado determinado pela confecção de uma abertura, realizada na córtex vestibular da lesão. Em oito pacientes, a cavidade foi encontrada seca e completamente desprovida de conteúdo, em sete havia fluido serosanguinolento e em dois fluido hemorrágico. Todos os 17 cistos estavam completamente desprovidos de revestimento de tecido mole, com pequenos fragmentos enviados para exame microscópico, o qual revelou tecido conjuntivo, e ausência de tecido epitelial. Durante a exploração cirúrgica da cavidade cística, os ápices ou raízes dos dentes projetavam-se para dentro da cavidade, e o controle a respeito de suas vitalidades revelaram que a polpa se mantinha vital, mesmo após exploração instrumental das raízes e ápices dentários.

Uma variação no tratamento do cisto ósseo traumático foi proposta por BIEWALD7 ${ }^{7}$, em 1967, na qual sete pacientes foram tratados pela injeção de 8 a $10 \mathrm{ml}$ de sangue venoso autógeno dentro da cavidade cística, após a aspiração do fluido cístico, através de uma pequena abertura realizada com uma broca número oito. $\mathrm{A}$ análise do fluido removido da cavidade evidenciou ser soro sangüíneo, com elevado conteúdo de bilirrubina. Evidências radiográficas de reparo ósseo puderam ser observadas 12 a 20 semanas após o procedimento. 
Todos os 22 casos de cisto ósseo traumático relatados por MORRIS et al. ${ }^{79}$, em 1970, foram tratados por exploração cirúrgica simples, por ser 0 tratamento mais indicado e curativo. Apenas um caso continha algum tipo de tecido mole na cavidade cística, seis estavam completamente vazias, e 13 continham fluido. 0 tecido mole encaminhado para exame microscópico revelou tecido conjuntivo fibrovascular e ausência de epitélio ou outro componente que sugerisse origem odontogênica. Em várias áreas o estroma pareceu estar em degeneração mixomatosa, em algumas havia uma aparência reparadora com capilares de paredes finas e estroma de tecido conjuntivo maturo. 0 infiltrado inflamatório foi mínimo. $O$ fenômeno degenerativo existente poderia caracterizar a preexistência de um tumor. Os autores ${ }^{79}$ enfatizaram que, na maioria das lesões, nenhum tecido mole foi encontrado, não tendo importância alguma os achados isolados.

Cento e cinqüenta casos de cisto ósseo traumático foram revisados por HUEBNER; TURLINGTON54, em 1971. O tratamento empregado em quase todos os casos foi o cirúrgico, para visualização e curetagem da cavidade cística. Dos 150 casos, $72 \%$ não tinham nenhum tipo de revestimento e 52 cavidades estavam completamente vazias. Com relação ao exame microscópico, apenas 64 lesões foram examinadas. Nenhum revestimento epitelial foi encontrado, mas áreas de atividade osteoclástica e osteoblástica estavam, æ̀ vezes, presentes. O tecido conjuntivo que em alguns casos revestia a cavidade, era fino e continha numerosos vasos sangüíneos. Tecido de granulação, células xantomatosas e células gigantes foram ocasionalmente vistas. Os autores ${ }^{54}$ concluíram que os achados microscópicos não foram patognomônicos da lesão. Em relação ao prognóstico do cisto ósseo traumático, dos 150 casos tratados, apenas dois sofreram recorrência. 
Os 66 casos clínicos de cisto ósseo traumático, descritos por HANSEN et al.43, em 1974, foram tratados cirurgicamente consistindo, apenas, na abertura da cavidade, remoção do conteúdo e sutura da ferida. A hemorragia dentro da cavidade foi necessária para a formação do coágulo que, em contato com o tecido conjuntivo, foi substituído por osso. Os aspectos cirúrgicos e microscópicos foram, assim descritos:

\section{Aspectos cirúrgicos em 60 pacientes}

\begin{tabular}{|l|c|}
\hline Cavidade seca e vazia & 30 \\
\hline Cavidade com fluido (marrom, amarelo, seroso, sangüíneo, etc.) & 23 \\
\hline Cavidade com lóbulos de gordura & 2 \\
\hline Cavidade com "tecido de granulação" & 5 \\
\hline
\end{tabular}

Fonte: HANSEN et al..$^{43}$, em 1974.

\section{Aspectos microscópicos em 35 pacientes}

\begin{tabular}{|l|c|}
\hline Osso normal & 16 \\
\hline Tecido conjuntivo fibroso & 10 \\
\hline Medula hematopoiética & 4 \\
\hline Medula adiposa & 3 \\
\hline Tecido conjuntivo fibroso vascular ou "hemangioma" & 2 \\
\hline Sangue & 2 \\
\hline Hemossiderina intracelular e extracelular & 1 \\
\hline Pus & 1 \\
\hline Ausência de epitélio & 35 \\
\hline
\end{tabular}

Fonte: HANSEN et al. ${ }^{43}$, em 1974. 
O sucesso do tratamento nos 30 casos de cisto ósseo traumático apresentados por BEASLEY ${ }^{5}$, em 1976, consistiu, essencialmente, na exposição da lesão e curetagem para a formação do coágulo que, subseqüentemente, se organizou e preencheu a cavidade com osso viável, não ocorrendo recidiva em nenhum caso. Os aspectos cirúrgicos foram variáveis, com conteúdo semifluido ou mucóide ou a cavidade estava desprovida de fluido ou tecido, com aspiração negativa. Ocasionalmente, fragmentos de tecido mole e pseudomembranas foram obtidas. A maioria dos tecidos submetidos para exame microscópico foi tecido mole e fragmentos de osso removidos das paredes da cavidade. Os aspectos microscópicos evidenciaram, principalmente, a presença de células sangüíneas vermelhas extravasadas, tecido fibromixomatoso degenerado, membranas hemorrágicas e outras alterações compatíveis com processo degenerativo. As evidências histológicas apontaram para um processo degenerativo, que não pôde ser adequadamente explicado.

Todos os 17 casos de cisto ósseo traumático associados à displasia óssea florida descritos por MELROSE et al. ${ }^{74}$, em 1976, foram explorados cirurgicamente e o material removido enviado para análise microscópica. A aspiração revelou pequena quantidade de fluido em 12 casos e a cavidade estava vazia em cinco casos. Durante a inspeção cirúrgica, os cistos mostraram-se de limites definidos, exceto em um caso em que foi impossível precisar os limites da cavidade, mesmo com a criação de uma grande abertura na cortical lingual expandida, na região de incisivos. Os cistos estavam, geralmente, revestidos por células fusiformes achatadas e alongadas, freqüentemente sustentadas por uma estreita faixa de tecido conjuntivo fibroso. Ocasionalmente, o revestimento cístico exibiu uma camada de células roliças, lembrando osteoblastos. Em vários casos não havia tecido conjuntivo, sendo o material caracterizado pela formação de uma matriz eosinofilica, lembrando osteóide, a qual os sais de cálcio foram depositados em um padrão distrófico fuziforme. A análise do fluido 
cístico mostrou níveis elevados de fosfatase alcalina e ácido fosfórico. Três casos não responderam ao tratamento, outros tiveram resolução parcial e os casos que tiveram cura mostraram aparência radiográfica de tecido mineralizado anormal.

Um novo método de tratamento por uma técnica de diagnósticocuretagem foi proposto por DAVIS JUNIOR et al. ${ }^{23}$, em 1979, ao reportar 15 novos casos de cisto ósseo traumático. Seis casos foram tratados convencionalmente, para comparação posterior. Nos outros nove casos, a lesão foi penetrada por uma agulha de calibre 18, através de um pequeno orifício confeccionado na cortical óssea. Após se estabelecer que a lesão continha sangue vermelho rutilante, vários centímetros cúbicos de sangue foram injetados para dentro da cavidade e as paredes foram curetadas com a ponta da agulha. Seguindo este procedimento o reparo ósseo completo do cisto ocorreu num período de três a oito meses, semelhante ao grupo controle. Os autores ${ }^{23}$ enfatizaram que para a aplicação do método, certos critérios devem ser obedecidos: (1) a lesão deve mostrar imagem radiolúcida sem revestimento aparente; (2) usualmente assintomática, com pouca ou nenhuma expansão da cortical; (3) conter sangue vermelho rutilante ou fluido serossanguinolento na aspiração (usualmente em volume maior que 0 da cavidade); (4) teste de vitalidade positivo dos dentes adjacentes àlesão. Tratada pelo método diagnóstico-curetagem, a lesão deve ser observada por repetidas radiografias até o completo reparo ósseo. As grandes vantagens deste método são a redução das seqüelas pós-cirúrgicas e das injúrias æ̇s estruturas vizinhas, tais como dentes e nervos.

PRECIOUS; MCFADDEN93, em 1984, apresentaram um caso de cisto ósseo traumático, o qual não respondeu à curetagem cirúrgica convencional, demonstrando um aumento no tamanho e uma aparência multilocular. Os autores usaram uma técnica de injeção de sangue autógeno dentro da cavidade, produzindo rápida formação óssea e resolução da lesão. 0 procedimento consistiu na remoção de $20 \mathrm{ml}$ de 
sangue de uma veia do paciente e posterior injeção dentro da cavidade através do retalho mucoperiosteal, o qual tinha sido suturado após exploração cirúrgica do cisto. A injeção de sangue autógeno dentro da cavidade óssea foi realizada com a finalidade de estimular a osteogênese.

A intervenção endodôntica no tratamento do cisto ósseo traumático foi questionada por vários autores 5,23,37,43,54,79,132. Porém, em 1987, dois trabalhos mostraram a importância da terapia endodôntica na cura do cisto ósseo traumático. RUIZ-HUBARD; HARRISON102 relataram um caso de cisto ósseo traumático, em um homem de 47 anos de idade, no qual duas intervenções cirúrgicas não levaram à cura do cisto. 0 paciente foi então encaminhado ao endodontista para tratamento do dente envolvido, revelando cura completa da lesão pelas evidências radiográficas e clínicas posteriores. 0 caso relatado sugeriu que um dente endodonticamente envolvido, associado a um cisto ósseo traumático, pode impedir a cura, mesmo após intervenção cirúrgica, sendo a eliminação dos fatores irritantes necessária para o reparo ósseo. NEWTON; ZUNT ${ }^{83}$ também enfatizaram o papel do tratamento endodôntico nos dentes associados ao cisto ósseo traumático, alegando a possibilidade de desvitalização dos dentes adjacentes ao cisto, durante o tratamento cirúrgico. Os autores sugeriram que se a vitalidade pulpar dos dentes for duvidosa, a terapia endodôntica deve ser realizada antes da cirurgia.

KAUGARS; CALE61, em 1987, declararam que o exame microscópico do cisto ósseo traumático deveria ser realizado a fim de confirmar 0 diagnóstico clínico. Nos 67 casos relatados, 65,7\% apresentaram inflamação, 28,4\% osso medular, $22,4 \%$ fibras nervosas, $13,4 \%$ osteóide, $13,4 \%$ células gigantes tipo osteoclastos e $7,5 \%$ colesterol. O tratamento empregado nos casos relatados foi a exploração cirúrgica, seguida por curetagem das paredes ósseas, ocorrendo regeneração dentro de 
alguns meses. Os autores ${ }^{61}$ discordaram dos trabalhos ${ }^{83,102}$ que defenderam o tratamento endodôntico nos dentes cujos ápices estão envolvidos na área cirúrgica, pois os dentes são quase sempre vitais, e a lesão apresenta um excelente prognóstico, curando sem complicação. A resolução espontânea do cisto ósseo traumático é sugerida pelo pequeno número de casos encontrados em adultos ${ }^{107}$. Entretanto, não se pode recomendar apenas a observação de lesões que são compatíveis radiograficamente com o cisto ósseo traumático, devido a possibilidade de um diagnóstico errôneo.

Todos os 23 cistos ósseos traumáticos descritos por FORSSELL et al. ${ }^{31}$, em 1988, foram tratados por exploração cirúrgica com a finalidade de confirmar o diagnóstico presuntivo. Quinze cavidades estavam vazias, duas continham fluido seroso, três fluido sanguinolento e tecido desgarrado em três cistos, nenhum caso apresentou tecido capsular. Dois cistos não curaram após a primeira intervenção cirúrgica, deixando claro a necessidade de acompanhamento dos pacientes tratados, a fim de confirmar a cura completa da lesão. Análise microscópica dos espécimes foi realizada em 17 casos. Doze espécimes continham a placa óssea removida da cortical vestibular e seis consistiam de material de curetagem das paredes da cavidade cística. Vários graus de distúrbios na arquitetura foram encontrados na maioria dos cistos: osteoblastos proeminentes margeando a cavidade foram vistos em quatro espécimes, e células gigantes do tipo osteoclastos estavam presentes em um caso. Nenhum tecido mole de revestimento foi observado em nove casos e em outros, o revestimento consistiu em tecido conjuntivo frouxo vascular, com hemorragia marcante. 
Os 19 cistos ósseos traumáticos relatados por SAITO et al. ${ }^{106}$, em 1992, foram submetidos à intervenção cirúrgica, para confirmação do diagnóstico e tratamento. Dois cistos recidivaram, sendo um destes associado àdisplasia óssea florida. Todos os dentes relacionados com radiopacidade periapical foram extraídos e as lesões radiopacas remanescentes foram meticulosamente removidas em uma segunda exploração cirúrgica. No grupo de pacientes jovens, seis cistos não apresentaram tecido de revestimento e em cinco as cavidades estavam revestidas por tecido mole. No grupo idoso, tecido mole revestiu a cavidade em seis casos. Tecido suficiente para avaliação microscópica foi obtido em apenas dez cistos. Displasia cementária periapical foi 0 diagnóstico dos espécimes obtidos das lesões radiopacas associadas aos cistos.

SHEAR ${ }^{112}$, em 1992, relatou que o tratamento cirúrgico do cisto ósseo traumático é o usualmente recomendado porque, quando a cavidade é aberta e a hemorragia é promovida, resulta numa rápida obliteração da lesão. Como, no entanto, o cisto ósseo traumático regride espontaneamente, a necessidade de intervenção cirúrgica deveria ser questionada, especialmente se for determinado um diagnóstico apurado, em bases clínicas e radiográficas e, principalmente, se o paciente for capaz de atender a um seguimento radiográfico em intervalos periódicos ${ }^{112}$. Os aspectos microscópicos do cisto ósseo traumático, descritos por SHEAR ${ }^{112}$, revelaram uma membrana de tecido conjuntivo frouxo vascular, de espessura variável, sem revestimento epitelial, embora uma rede de fibrina com hemácias pudesse ser observada. Áreas hemorrágicas e pigmentos de hemossiderina estavam freqüentemente presentes, bem como células gigantes multinucleadas. Em algumas paredes císticas, provavelmente de casos de longa duração, havia uma maior densidade fibrosa. 0 osso adjacente, quando incluído na peça cirúrgica, apresentava reabsorção osteoclástica em sua superfície interna. 


\subsection{Associação do cisto ósseo traumático com outras doenças}

A associação do cisto ósseo traumático com outras doenças tem sido relatada na literatura com certa freqüência. Entre elas destacam-se:

- Displasia cementóssea florida26,45,49,61,71,74,77,99,106,127

- "Granuloma reparativo de células gigantes" 54,126

- Cisto ósseo aneurismático 50

- Displasia fibrosa ${ }^{44}$

- Lesão fibróssea não esclarecida ${ }^{29}$

- Osteogênese imperfeita60

- Queratocisto odontogênico73

- Dente não irrompido17,110

A importância de se destacar a associação do cisto ósseo traumático com outras doenças consiste em se conhecer os diferentes comportamentos biológicos de uma mesma lesão, podendo estas formas atípicas apareceream em qualquer idade, com comportamento mais agressivo e recidivante, mostrando que o cisto ósseo traumático pode ser um grupo heterogêneo de lesões com diferentes causas ${ }^{106}$.

MELROSE et al. ${ }^{74}$ sugeriram que a combinação do cisto ósseo traumático, especialmente com a displasia óssea florida, ocorre secundariamente como uma reação anormal do osso à irritação ou à estimulação. STIMSON; MACDANIEL ${ }^{115}$ também levantaram a hipótese do cisto ósseo traumático ser uma manifestação secundária de uma lesão preexistente.

\subsection{Relação com o cisto ósseo solitário (unicameral) dos ossos longos}


O cisto ósseo solitário dos ossos longos, também conhecido como unicameral ou cisto ósseo simples, é uma lesão não neoplásica comumente encontrada, classificado como uma lesão pseudotumoral, como relatado por GARCIA FILHO et al. ${ }^{36}$, em 1992. Este cisto usualmente ocorre em crianças na primeira e segunda décadas de vida, sendo levemente mais comum em homens. As regiões metafisárias do fêmur e do úmero são as mais comumente afetadas, podendo também ocorrer em outros ossos. O cisto ósseo solitário é descrito como uma cavidade simples irregular, contendo fluido amarelo-limão ou sangüinolento, revestido por uma membrana de tecido conjuntivo frouxo. Ocasionalmente septos ósseos podem ser encontrados, especialmente se houve fratura. Embora este cisto tenha sido descrito no século passado, sua etiologia não é clara e seu tratamento controverso, com uma taxa de recorrência entre 15 a 55\%.

A relação entre o cisto ósseo traumático dos maxilares e o cisto ósseo unicameral do esqueleto foi sugerida por vários autores ${ }^{10,53,58,59,86}$. KAUGARS; CALE ${ }^{61}$, em 1987, afirmaram que nenhuma evidência conclusiva provou que os dois representam o mesmo processo patológico, apesar de apresentarem características microscópicas similares, ocorrerem em pessoas jovens e terem aspectos radiográficos comparáveis. Porém, o cisto ósseo traumático dos maxilares não demonstra uma maior predileção por homens, sendo usualmente assintomático e menos susceptível a fraturas. Algumas destas diferenças devem ser atribuídas ao diagnóstico precoce através de radiografias de rotina para o tratamento dentário. Os autores ${ }^{61}$ ainda acrescentaram que a correlação entre o cisto ósseo traumático dos maxilares e o cisto ósseo unicameral dos ossos longos permanece indefinível, podendo representar o mesmo processo com manifestações clínicas dependentes do osso de origem.

SHEAR ${ }^{112}$, em 1992, relatou que o cisto ósseo traumático que ocorre quase sempre na mandíbula, não afetando a maxila, é muito semelhante e, 
provavelmente, idêntico ao cisto ósseo solitário ou unicameral, freqüentemente localizado nas metáfises da extremidade superior do úmero e do fêmur, em crianças e adolescentes. 
$\underline{3-P R O P O S I C A ̃ O}$ 


\section{PROPOSIÇÃO}

Observando a variedade de terminologia, desconhecimento da etiopatogenia e dúvidas sobre o comportamento biológico do cisto ósseo traumático, existentes na literatura, propusemo-nos a estudar esta doença, abordando os seguintes itens:

1. Estabelecer a epidemiologia da amostra estudada quanto ao gênero, raça, faixa etária, história clínica, tipo de radiografia utilizada, localização e conformação da imagem radiográfica;

2. Discutir as possibilidades da cura espontânea da doença, sugerindo critérios para a proservação das lesões não exploradas cirurgicamente;

3. Estudar a prevalência do cisto ósseo traumático em pacientes tratados ortodonticamente e discutir sua possível relação etiopatogênica. 
4-MATERIAL E MÉTODOS 


\section{MATERIAL E MÉTODOS}

\subsection{MATERIAL}

\subsubsection{Amostra número 1}

Foi constituída de 19 casos clínicos de cisto ósseo traumático em 17 pacientes (dois pacientes apresentavam lesões bilaterais). Nove casos compatíveis com a mesma doença, pelos aspectos clínicos e radiográficos, foram somados à amostra, elevando a 28 casos clínicos. Dezoito pacientes foram obtidos nos arquivos da Clínica de Estomatologia da Faculdade de Odontologia de Bauru, Universidade de São Paulo (FOB/USP) e os demais oito casos foram oferecidos por colegas cirurgiões-dentistas.

\subsubsection{Critérios clínicos, radiográficos, cirúrgicos e de proservação aplicados àamostra número 1.}

Para constituir esta amostra, os casos necessitavam apresentar os seguintes critérios clínicos, radiográficos, cirúrgicos (nos casos comprovados) e de proservação (nos casos compatíveis).

\section{Critérios clínicos}

- As lesões ocorriam na mandíbula;

- Os pacientes estavam, principalmente, na 2a década de vida;

- Lesões assintomáticas, diagnosticadas em exames radiográficos de rotina. 


\section{Critérios radiográficos}

- Imagens radiolúcidas de contornos delimitáveis em quase toda superfície, raramente com orla esclerótica e parcialmente presente (Figuras 4.1 A e B);

- As formas das imagens eram ovais ou arredondadas, ふ̀े vezes estendendo-se por entre as raízes dentárias, de aspecto crenado ("scalloping") (Figura 4.2);

- A rarefação óssea atingia principalmente a porção medular, podendo, raramente, haver discretas expansões e leves adelgaçamentos das corticais ósseas vestibular e lingual (Figuras $4.3 \mathrm{~A}$ e B).

\section{Critérios cirúrgicos}

Dezenove casos clínicos de 17 pacientes, foram comprovados por intervenções cirúrgicas, as quais revelaram:

- Cavidade essencialmente vazia, raramente contendo pequenas porções de líquido serossanguinolento (Figura 4.4).

\section{Critérios de proservação}

Nove casos clínicos foram considerados compatíveis, pois não houve exploração cirúrgica. Os critérios clínicos e radiográficos eram favoráveis e a proservação descartou outras doenças. Para que estes casos fossem considerados compatíveis, além da opinião do autor e orientador, a opinião de quatro examinadores Radiologistas foi considerada. Eles aprovaram a nossa opção de diagnóstico e concordaram com todos os critérios. A literatura sobre a doença foi fornecida aos examinadores, as radiografias foram cercadas por mascaras e examinadas no negatoscópio em ambiente escurecido. 
Os seguintes critérios de proservação foram adotados:

- Exame clínico e radiográfico 20 dias após a descoberta da lesão, sem sintomatologia constatável e com imagem radiográfica estável comparável àimagem de diagnóstico;

- Exame clínico e radiográfico de 60 dias mantendo as características iniciais ou mostrando involução da lesão;

- Exame clínico e radiográfico de seis meses mantendo as características iniciais ou de involução da lesão;

- Controle de um ano ou mais, repetindo aspectos já mencionados (Figuras 4.5 A e B).

\subsubsection{Amostra número 2}

Os prontuários de 956 pacientes com tratamento ortodôntico concluído, pertencentes à Disciplina de Ortodontia da FOB/USP foram analisados com vistas a se estabelecer a freqüência do cisto ósseo traumático na população estudada. Os dados foram coletados das fichas clínicas dos pacientes e das radiografias panorâmicas existentes. 


\subsubsection{Casos compatíveis com cisto ósseo traumático detectados na amostra número 2}

Após a análise das fichas clínicas e das radiografias panorâmicas existentes nos prontuários dos 956 pacientes com tratamento ortodôntico concluído, 12 prontuários foram separados para estudo. Entre eles:

- Dois casos eram comprovados, pois foram tratados cirurgicamente na Clínica de Estomatologia da FOB/USP, e já estavam incorporados àamostra número 1;

- Dez foram julgados suspeitos e separados para reavaliação 30 dias após. No segundo exame, quatro destes foram descartados devido a alguns fatores como:

- má qualidade das radiografias;

- os casos não se enquadravam, totalmente, nos critérios radiográficos propostos para a amostra número 1;

- a proservação do tratamento ortodôntico era incompleta para avaliação dos objetivos do trabalho. Consideramos apenas os casos cujo controle radiográfico se deu por pelo menos dois anos.

Os oito casos, seis com imagens radiográficas consideradas compatíveis com cisto ósseo traumático e dois casos comprovados, foram submetidos à opinião de quatro examinadores radiologistas que colaboraram no trabalho. Eles julgaram os casos como compatíveis ou não com cisto ósseo traumático (Tabela 4.1, Figuras 4.6 A e B). Para tal, Ihes foi oferecido a literatura sobre a doença e o ambiente de trabalho escurecido, com as radiografias cercadas por máscaras e examinadas no negatoscópio. 

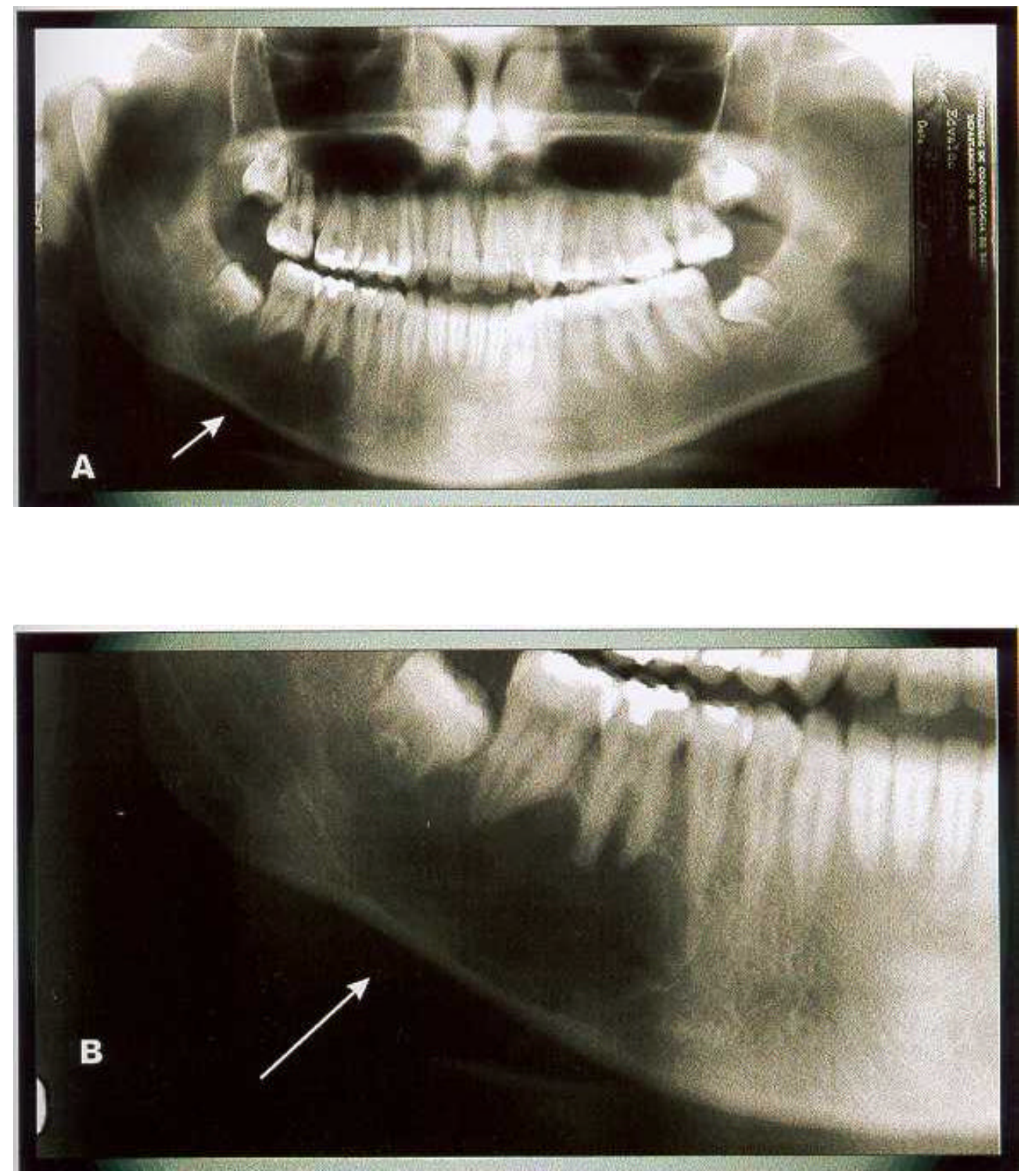

FIGURAS 4.1 A e B - Radiografia panorâmica mostrando imagem radiolúcida oval na mandíbula, de contornos delimitáveis em quase toda extensão, raramente com halo radiopaco (orla esclerótica) e parcialmente presente, com aparência típica do cisto ósseo traumático 


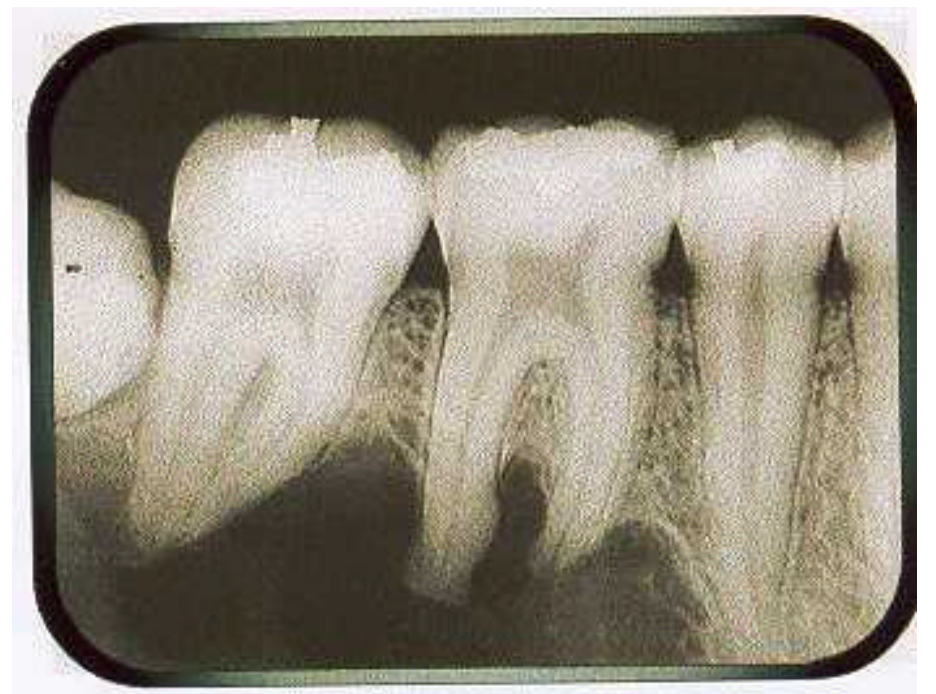

FIGURA 4.2 - Radiografia periapical demonstrando a forma oval do cisto ósseo traumático, estendendo se por entre as raízes dentárias, de aspecto crenado ("scalloping")
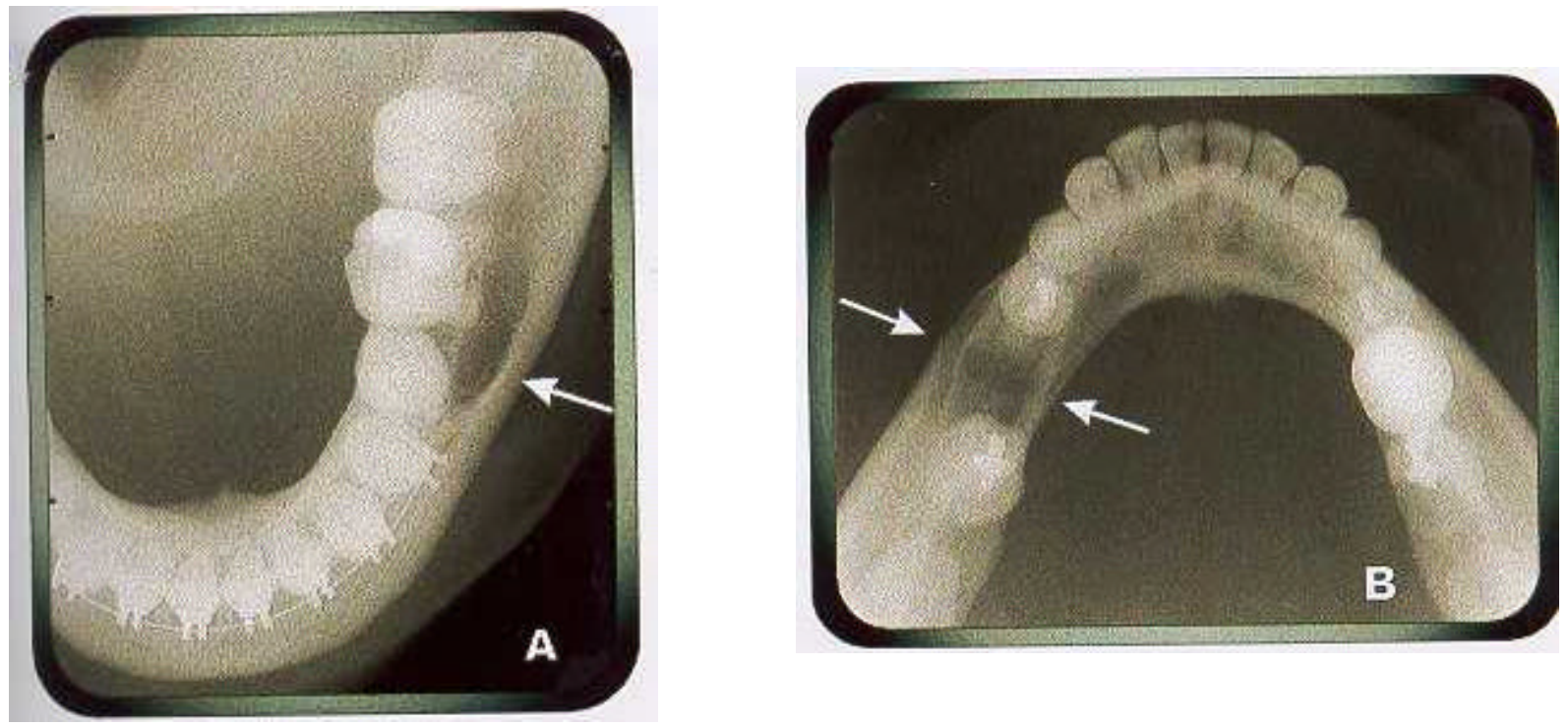

FIGURAS 4.3 A e B - Radiografia oclusal de um caso de cisto ósseo traumático, A - mostrando rarefação óssea atingindo a porção medular, sem expansão das corticais ósseas; B - leve adelgaçamento das corticais ósseas vestibular e lingual 


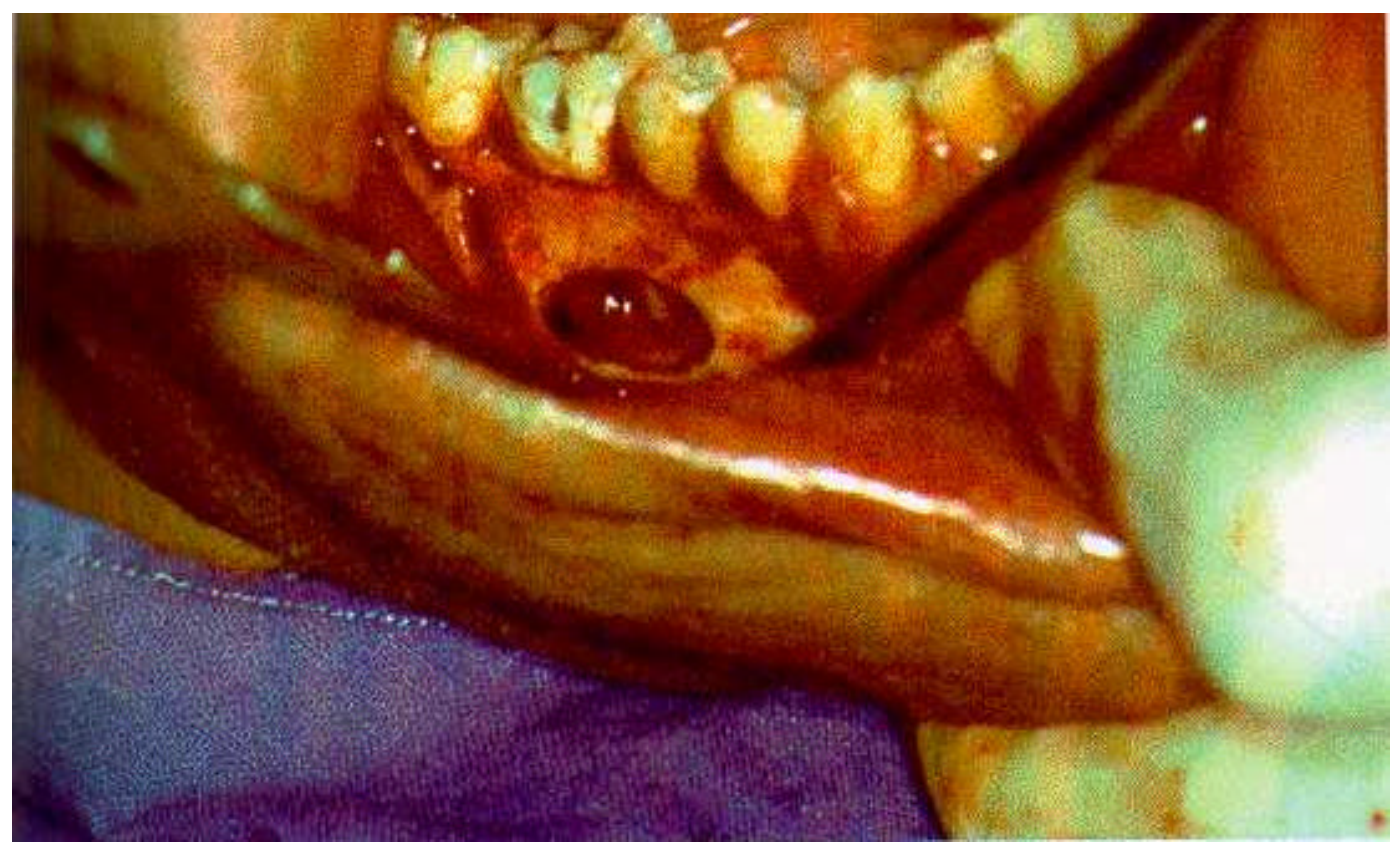

FIGURA 4.4 - Aspecto cirúrgico do cisto ósseo traumático, que revelou cavidade vazia, mostrando os ápices radiculares expostos na cavidade cística 

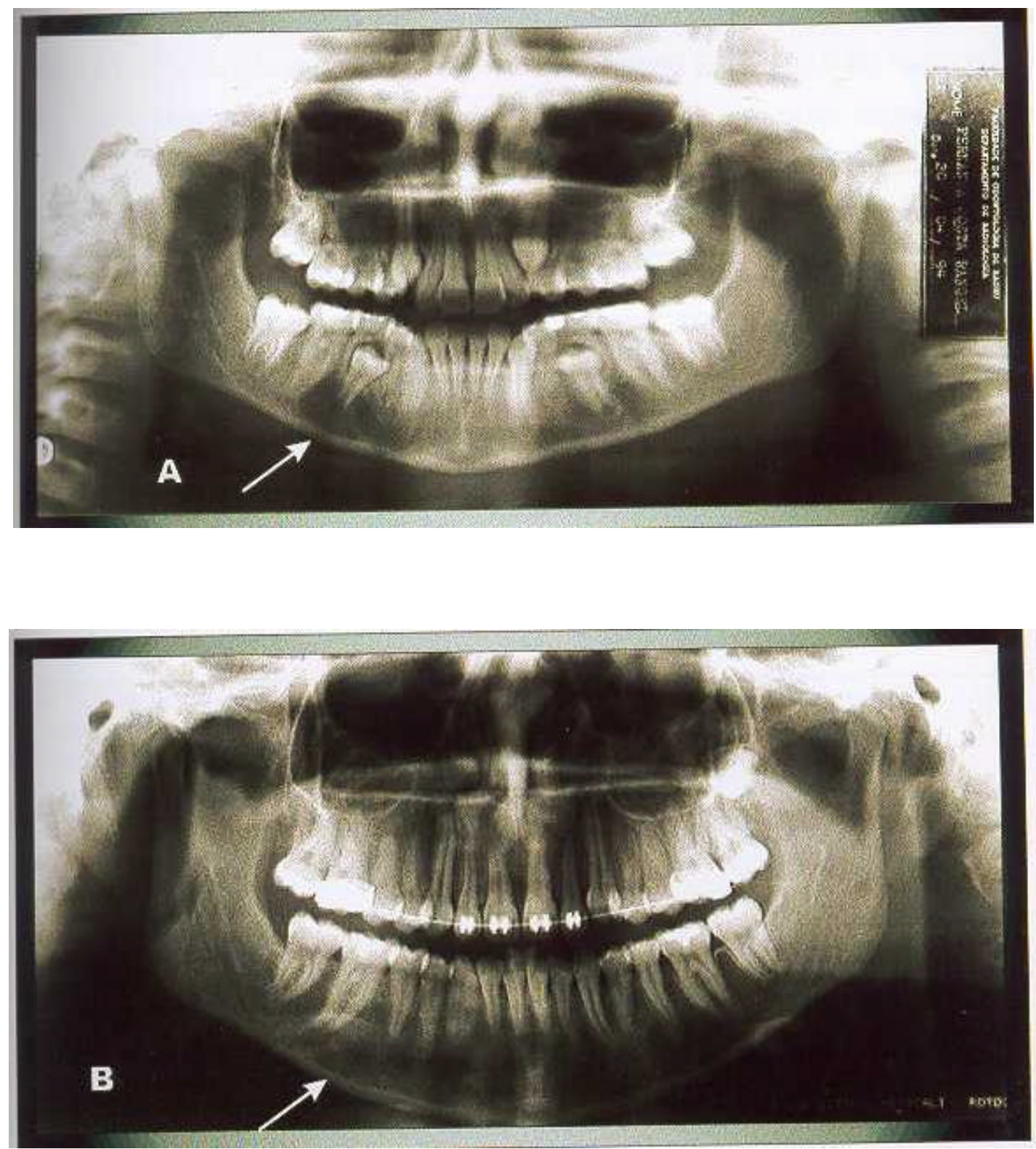

FIGURAS 4.5 A e B - Exame radiográfico inicial (A) e de 2 anos de controle (B), apresentando involução da lesão 
TABELA 4.1 - Distribuição das opiniões de quatro examinadores (especialistas em Radiologia) sobre a compatibilidade com o diagnóstico radiográfico de cisto ósseo traumático: Estudo de oito cistos levantados, entre 956 pacientes com tratamento ortodôntico concluído

\begin{tabular}{|c|c|c|c|c|}
\hline CASOS* & Examinador $\mathrm{A}$ & Examinador $B$ & Examinador C & Examinador D \\
\hline 1 & $\mathrm{NC}$ & $\bar{c}$ & NC & $\bar{C}$ \\
\hline 2 & C & C & C & C \\
\hline 3 & C & C & NC & C \\
\hline 4 & C & C & C & C \\
\hline 5 & C & C & C & C \\
\hline 6 & C & C & C & C \\
\hline $7^{\#}$ & C & C & C & C \\
\hline $8^{\#}$ & C & C & C & C \\
\hline
\end{tabular}



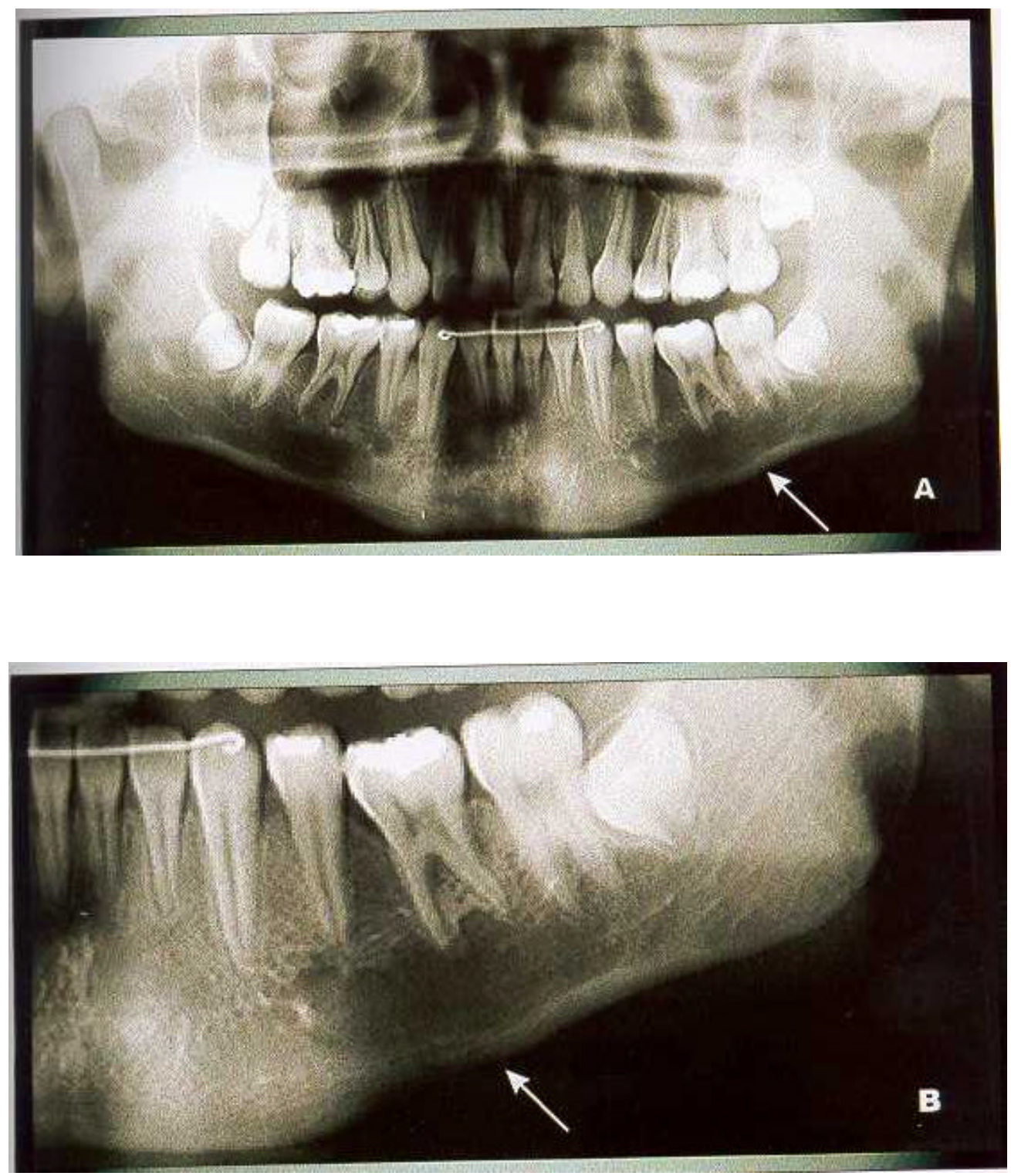

FIGURA 4.6 A e B - Radiografia panorâmica demonstrando um caso da amostra número 2 considerado compatível com cisto ósseo traumático 


\subsection{MÉTODOS}

\subsubsection{Amostra número 1}

Os dados foram coletados das fichas clínicas dos pacientes e dos exames radiográficos existentes, sendo os seguintes aspectos analisados:

\section{- Aspectos clínicos:}

$\Rightarrow$ Gênero;

$\Rightarrow$ Raça;

$\Rightarrow$ Faixa etária;

$\Rightarrow$ História clínica:

- história de trauma;

- história de tratamento ortodôntico;

- história ausente.

- Aspectos radiográficos:

$\Rightarrow$ Radiografias examinadas;

$\Rightarrow$ Localização: maxila ou mandíbula (sínfise, corpo, ramo);

$\Rightarrow$ Conformação da imagem (redonda, oval, unilocular, multilocular).

- Proservação dos casos compatíveis:

$\Rightarrow$ Tempo de controle;

$\Rightarrow$ Estado atual da imagem radiográfica;

$\Rightarrow$ Sintomatologia. 


\subsubsection{Amostra número 2}

Os dados foram coletados das fichas clínicas dos pacientes e das radiografias panorâmicas existentes, sendo os seguintes aspectos analisados:

$\Rightarrow$ Faixa etária dos 956 pacientes com tratamento ortodôntico concluído;

$\Rightarrow$ Relação do momento do diagnóstico dos 8 casos de cisto ósseo traumático com a etapa do tratamento ortodôntico.

\subsubsection{Amostra número 1 e 2 relacionadas ao tratamento ortodôntico}

Os dados foram coletados do somatório de casos de cisto ósseo traumático envolvidos com o tratamento ortodôntico sendo o seguinte aspecto analisado:

$\Rightarrow$ Relação do momento do diagnóstico com a etapa do tratamento ortodôntico. 
$\underline{5-R E S U L T A D O S}$ 


\section{RESULTADOS}

Os resultados serão apresentados descrevendo-se os aspectos clínicos e radiográficos da amostra número 1 (19 casos clínicos comprovados e nove casos compatíveis), bem como a proservação dos casos compatíveis da amostra número 1. Os dados dos casos compatíveis, detectados em radiografias panorâmicas, da amostra número 2 (pacientes com tratamento ortodôntico concluído) também serão demonstrados. A relação entre as amostras número 2 e 1 com história de tratamento ortodôntico será apresentada. As particularidades relevantes, a cada tópico, serão destacadas ao longo do texto.

\subsection{Resultados da amostra número 1}

\subsubsection{Aspectos clínicos}

Os aspectos epidemiológicos da amostra número 1, quanto ao gênero, raça, faixa etária e história clínica referentes a trauma e/ou tratamento ortodôntico são encontrados nas Tabelas 5.1, 5.2, 5.3, 5.4, 5.5 e nas Figuras 5.1, 5.2, 5.3, 5.4, 5.5. 
TABELA 5.1 - Distribuição do número de pacientes e de casos clínicos de cisto ósseo traumático, quanto ao gênero

\begin{tabular}{ccccc}
\hline \hline GÉNERO & \multicolumn{2}{c}{ № DE PACIENTES } & \multicolumn{2}{c}{ № DE CASOS CLÍNICOS } \\
& $\mathbf{N}$ & $\%$ & $\boldsymbol{N}$ & $\%$ \\
\hline \hline Masculino & 12 & 46,15 & 12 & 42,85 \\
Feminino & 14 & 53,85 & $16^{*}$ & 57,15 \\
\hline Total & 26 & 100 & 28 & 100 \\
\hline \hline
\end{tabular}

* Dois pacientes do gênero feminino apresentavam lesões bilaterais, sendo um caso associado àdisplasia cementóssea florida.

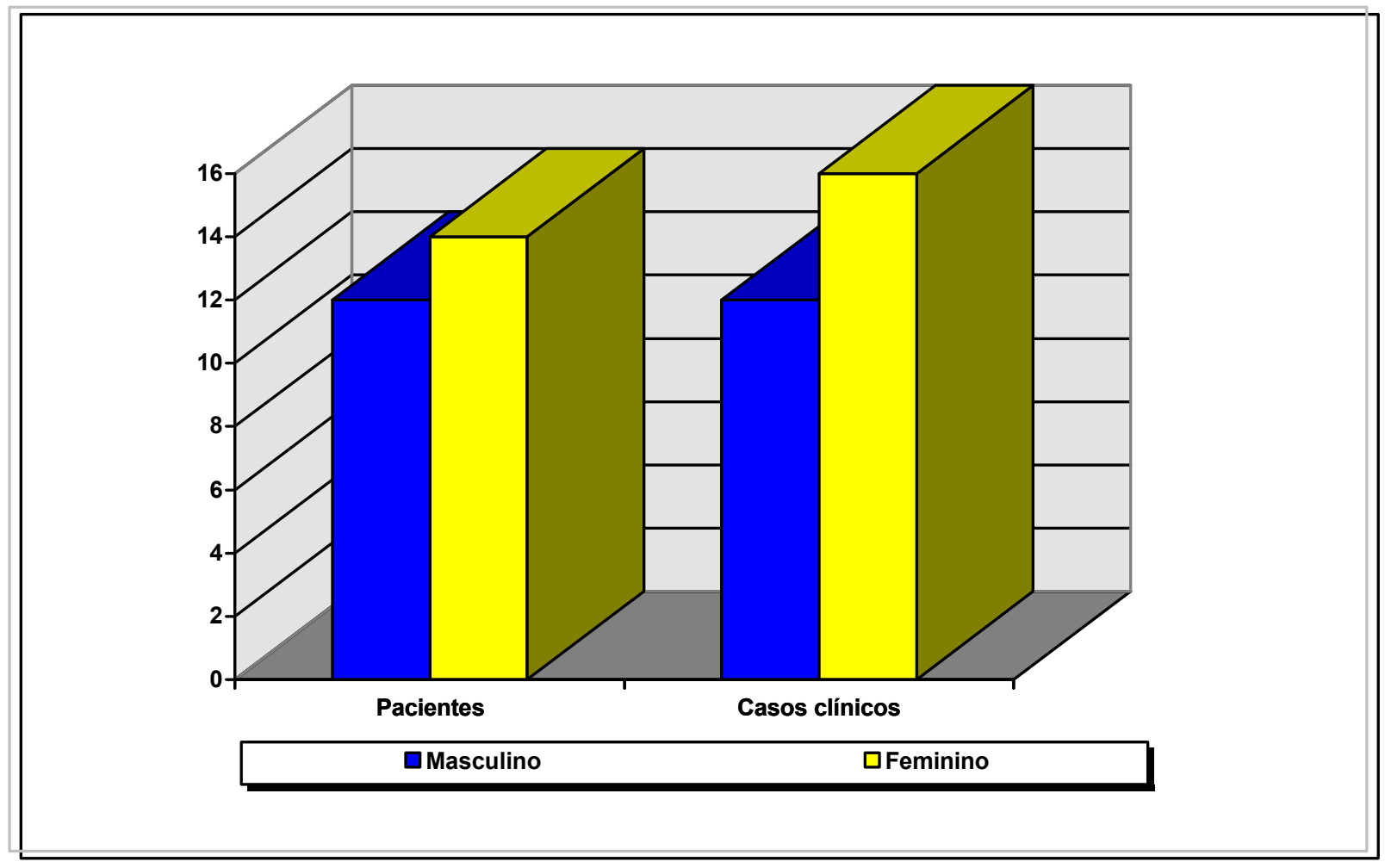

FIGURA 5.1 - Distribuição do número de pacientes e de casos clínicos de cisto ósseo traumático, quanto ao gênero 
TABELA 5.2 - Distribuição do número de pacientes e de casos clínicos de cisto ósseo traumático quanto àraça

\begin{tabular}{ccccc}
\hline \hline RAÇA & \multicolumn{2}{c}{ № DE PACIENTES } & \multicolumn{2}{c}{ № DE CASOS CLÍNICOS } \\
& $\mathbf{N}$ & $\%$ & $\mathbf{N}$ & $\%$ \\
\hline \hline Branca & 19 & 73,07 & 19 & 67,86 \\
Negra & 5 & 19,23 & 7 & 25 \\
Mestiço & 2 & 7,70 & 2 & 7,14 \\
\hline Total & 26 & 100 & 28 & 100 \\
\hline \hline
\end{tabular}

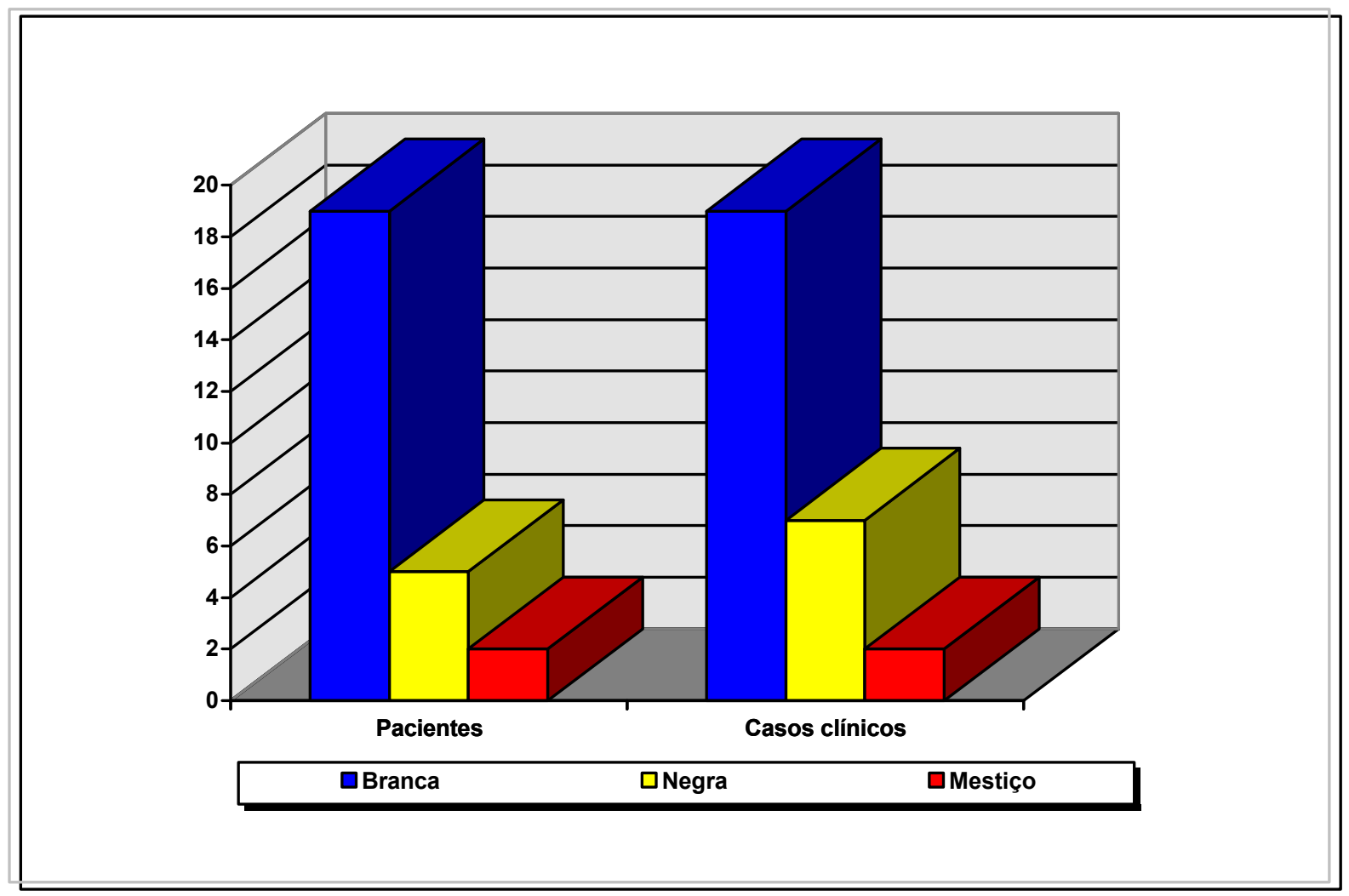

FIGURA 5.2 - Distribuição do número de pacientes e de casos clínicos de cisto ósseo traumático quanto àraça 
TABELA 5.3 - Distribuição do número de pacientes e de casos clínicos de cisto ósseo traumático, quanto àfaixa etária

\begin{tabular}{|c|c|c|c|c|}
\hline \multirow{2}{*}{$\begin{array}{c}\text { FAIXAS ETÁRIAS } \\
\text { (anos) }\end{array}$} & \multicolumn{2}{|c|}{ № DE PACIENTES } & \multicolumn{2}{|c|}{ № DE CASOS CLIÍNICOS } \\
\hline & $N$ & $\%$ & $N$ & $\%$ \\
\hline $5-10$ & $\overline{1} 1$ & 3,85 & 1 & 3,37 \\
\hline $11-15$ & 12 & 46,15 & 13 & 46,44 \\
\hline $16-20$ & 10 & 38,45 & 10 & 35,71 \\
\hline $21-25$ & 1 & 3,85 & 1 & 3,57 \\
\hline $26-30$ & 1 & 3,85 & 1 & 3,57 \\
\hline mais de 30 & 1 & 3,85 & 2 & 7,14 \\
\hline Total & 26 & 100 & 28 & 100 \\
\hline
\end{tabular}

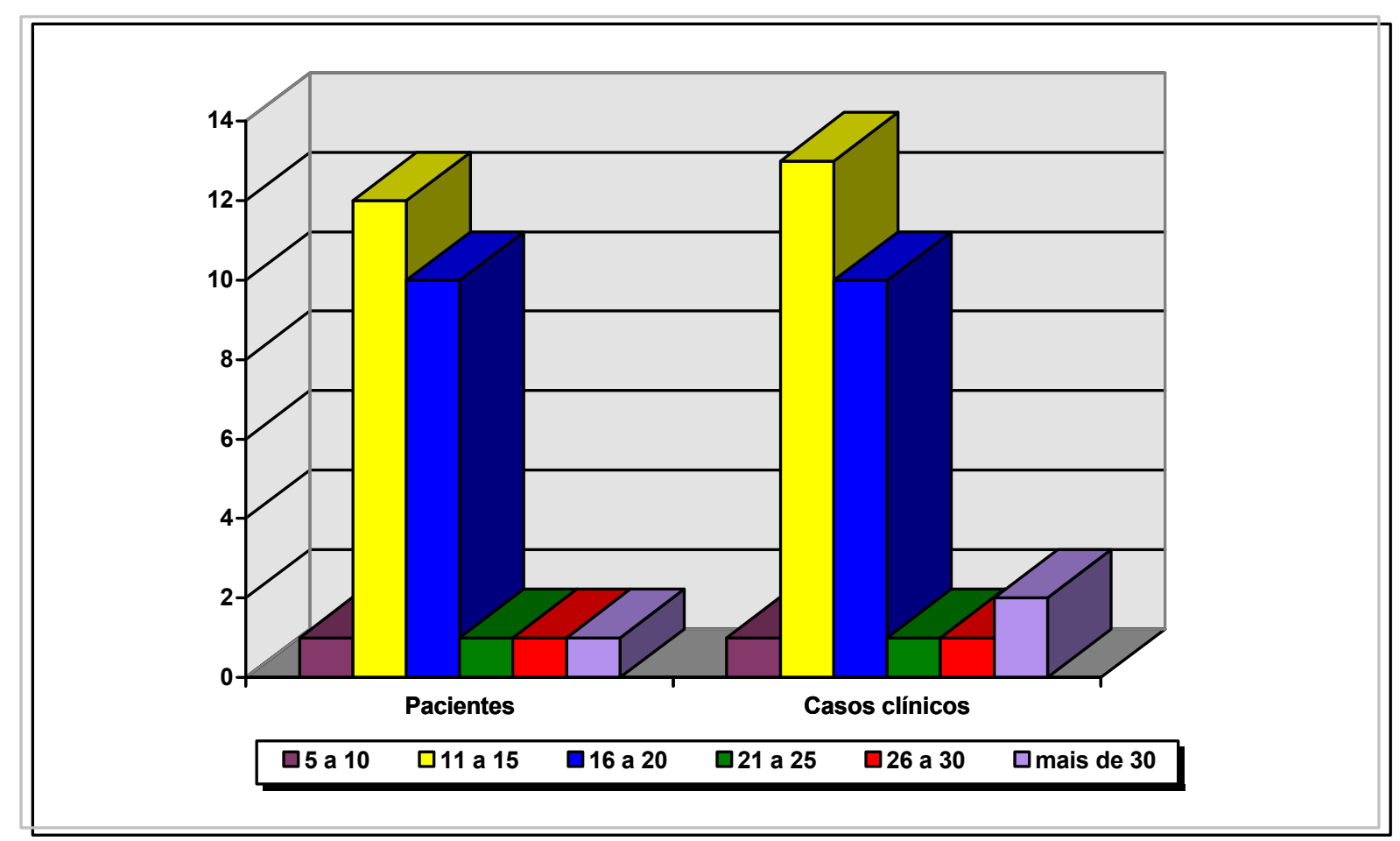

FIGURA 5.3 - Distribuição do número de pacientes e de casos clínicos de cisto ósseo traumático, quanto àfaixa etária 
TABELA 5.4 - Distribuição do número de pacientes e de casos clínicos de cisto ósseo traumático quanto àhistória de trauma, tratamento ortodôntico ou ausência de história

\begin{tabular}{ccccc}
\hline \hline HISTÓRIA & No DE PACIENTES & \multicolumn{2}{c}{ № DE CASOS CLÍNICOS } \\
& $\mathbf{N}$ & $\%$ & $\mathbf{N}$ & $\%$ \\
\hline \hline Trauma & $8^{*}$ & 30,77 & 8 & 28,57 \\
Tratamento ortodôntico & 18 & 69,23 & 18 & 64,28 \\
Ausente & 7 & 27 & 9 & 32,14 \\
\hline \hline
\end{tabular}

* Sete pacientes apresentavam história simultânea de trauma e de tratamento ortodôntico.

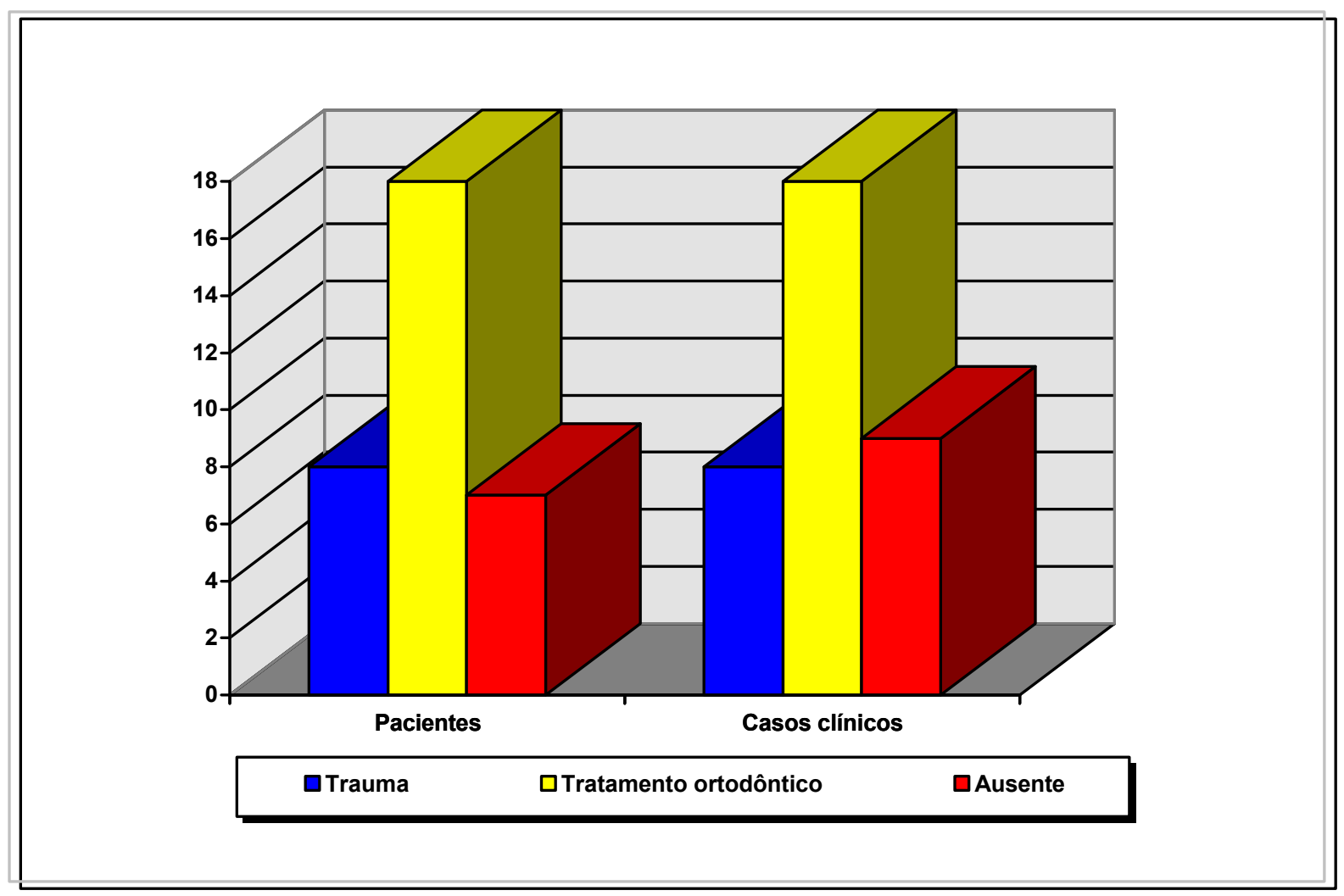

FIGURA 5.4 - Distribuição do número de pacientes e de casos clínicos de cisto ósseo traumático quanto àhistória de trauma, tratamento ortodôntico ou ausência de história 
TABELA 5.5 - Distribuição dos pacientes portadores de cisto ósseo traumático quanto à história de tratamento ortodôntico em relação ao momento do diagnóstico

\begin{tabular}{ccc}
\hline \hline $\begin{array}{c}\text { HISTÓRIA DE TRATAMENTO } \\
\text { ORTODÔNTICO }\end{array}$ & \multicolumn{2}{c}{ No DE PACIENTES } \\
\hline \hline antes* & 9 & $\%$ \\
durante & 6 & 33,33 \\
após & 3 & 16,66 \\
\hline Total & 18 & 100 \\
\hline \hline
\end{tabular}

* Documentação ortodôntica inicial

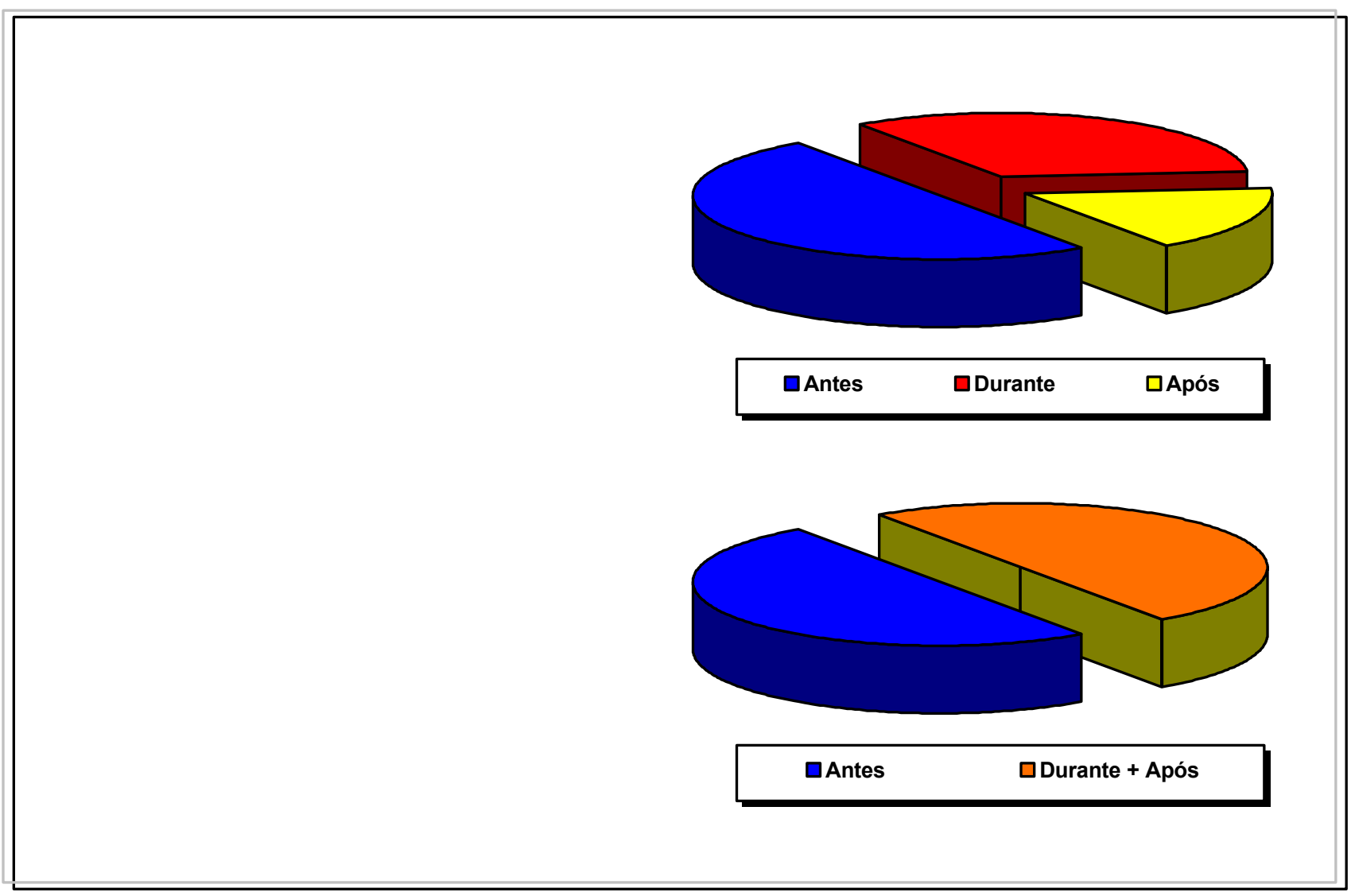

FIGURA 5.5 - Distribuição dos pacientes portadores de cisto ósseo traumático quanto à história de tratamento ortodôntico em relação ao momento do diagnóstico 


\subsubsection{Aspectos Radiográficos}

Os resultados dos aspectos radiográficos dos 28 casos clínicos de cisto ósseo traumático, referentes à radiografias examinadas, localização e conformação da imagem são encontrados nas Tabelas 5.6, 5.7 e 5.8 e nas Figuras 5.6, $5.7,5.8,5.9,5.10$ e 5.11 . 
TABELA 5.6 - Distribuição dos casos clínicos de cisto ósseo traumático, segundo o tipo de radiografia examinada

\begin{tabular}{ccc}
\hline \hline TIPOS DE RADIOGRAFIAS & \multicolumn{2}{c}{ № DE CASOS CLÍNICOS } \\
EXAMINADAS & $\mathbf{N}$ & $\%$ \\
\hline \hline Panorâmica & 28 & 100 \\
Periapical & 16 & 57,14 \\
Oclusal de mandíbula & 12 & 42,85 \\
\hline \hline
\end{tabular}

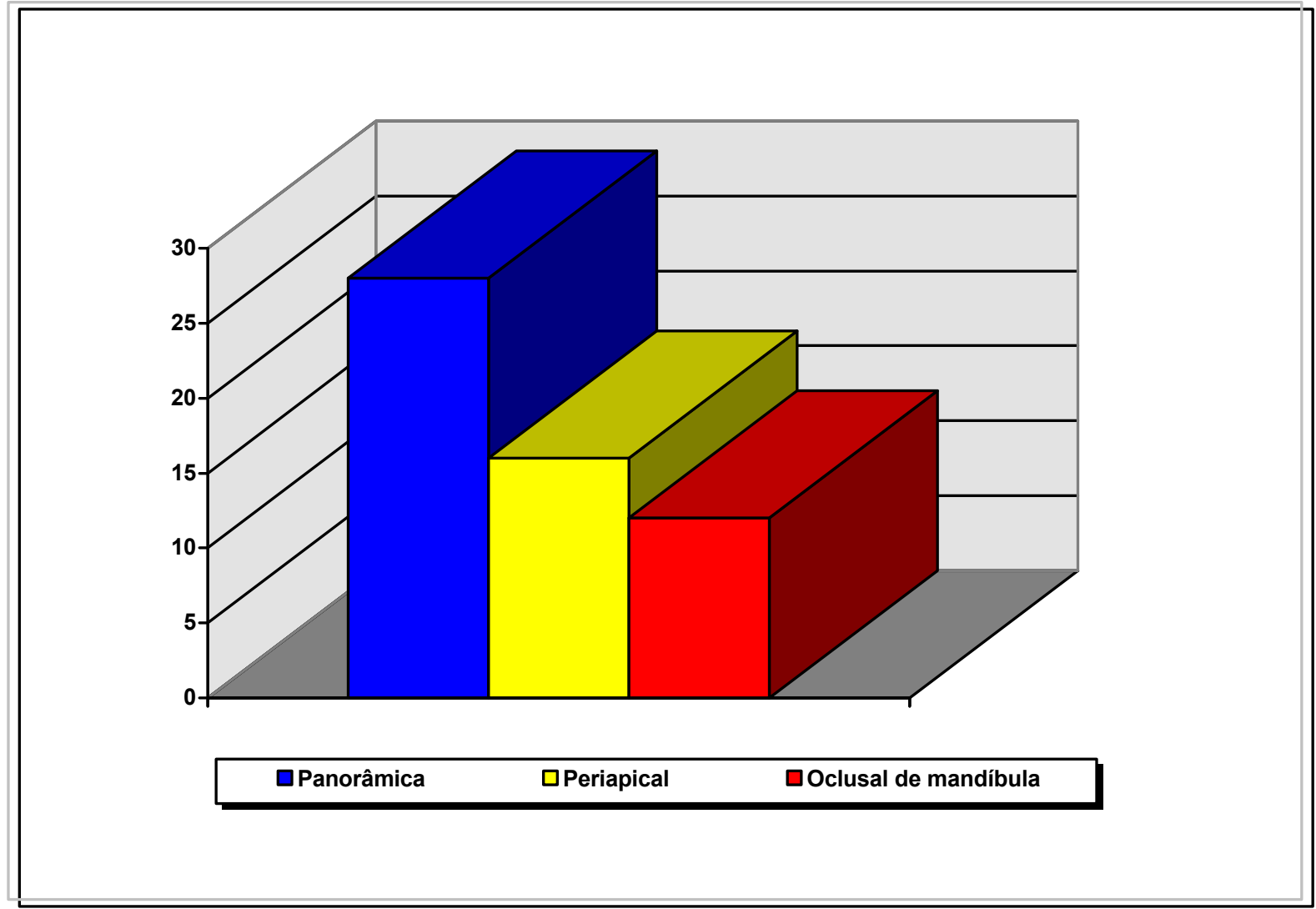

FIGURA 5.6 - Distribuição dos casos clínicos de cisto ósseo traumático, segundo o tipo de radiografia examinada 
TABELA 5.7 - Distribuição dos casos clínicos de cisto ósseo traumático, quanto à localização da doença

\begin{tabular}{ccc}
\hline \hline LOCALIZAÇÃO & № DE CASOS CLÍNICOS \\
& $\mathbf{N}$ & $\%$ \\
\hline \hline Mandíbula - sínfise & 2 & 7,14 \\
Mandíbula - sínfise e corpo & 3 & 10,71 \\
Mandíbula - corpo direito & 14 & 50 \\
Mandíbula - corpo esquerdo & 8 & 28,57 \\
Mandíbula - ramo ascendente & 1 & 3,57 \\
Maxila & 0 & 0 \\
\hline Total & 28 & 100 \\
\hline \hline
\end{tabular}

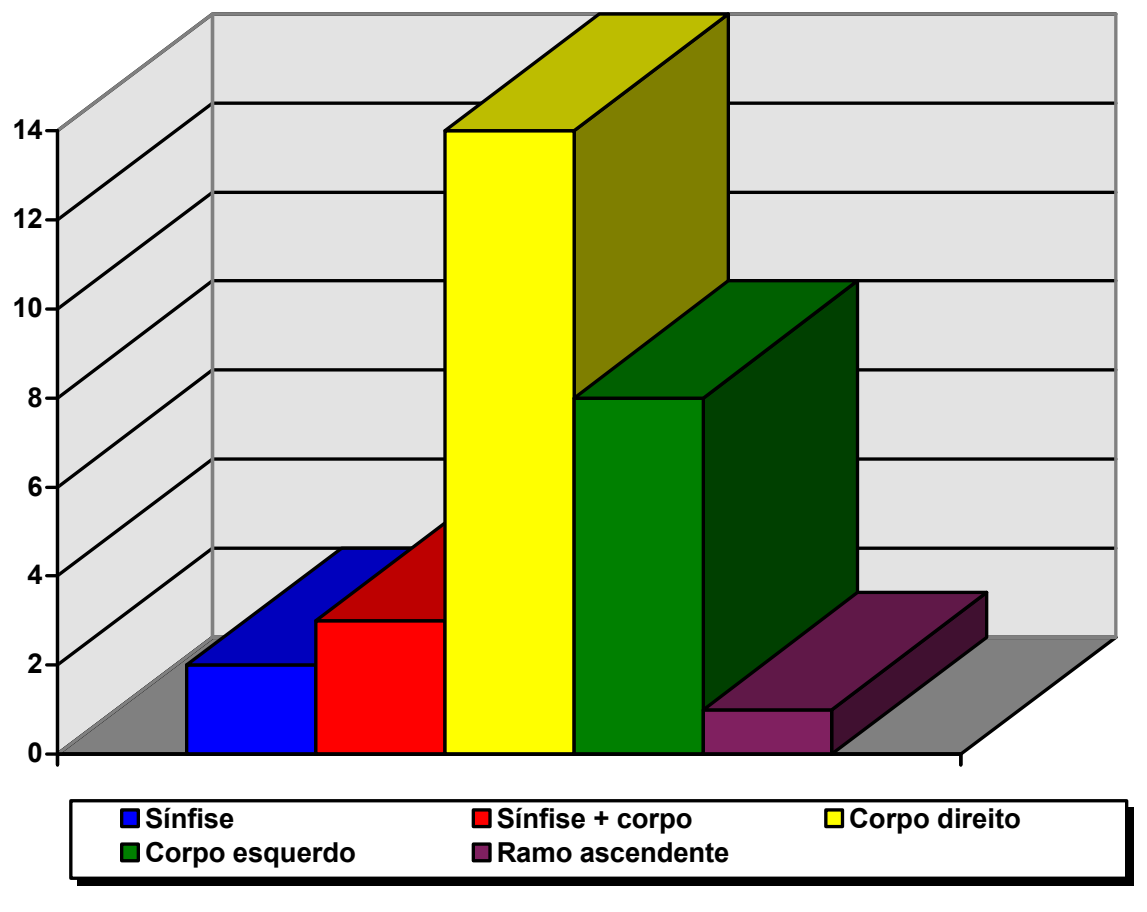

FIGURA 5.7 - Distribuição dos casos clínicos de cisto ósseo traumático, quanto à localização da doença 
TABELA 5.8 - Distribuição dos casos clínicos de cisto ósseo traumático segundo a conformação da imagem em radiografias panorâmicas

\begin{tabular}{ccc}
\hline \hline CONFORMAÇÃO DA IMAGEM & № DE CASOS CLÍ́NICOS \\
& $\mathbf{N}$ & $\%$ \\
\hline \hline Unilocular redonda & 4 & 14,29 \\
Unilocular oval & 23 & 82,14 \\
Multilocular & 1 & 3,57 \\
\hline Total & 28 & 100 \\
\hline \hline
\end{tabular}

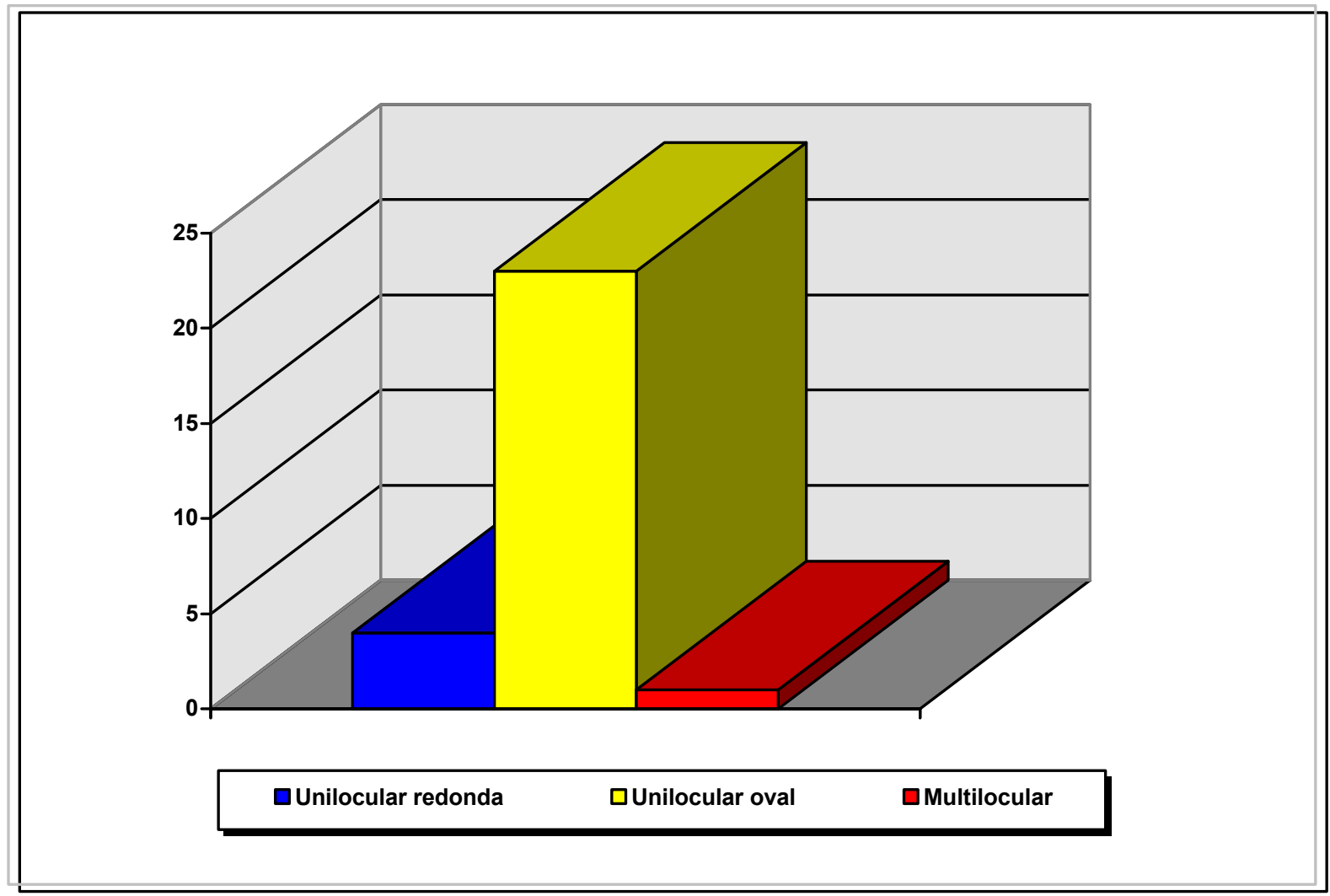

Figura 5.8 - Distribuição dos casos clínicos de cisto ósseo traumático segundo a conformação da imagem em radiografias panorâmicas 


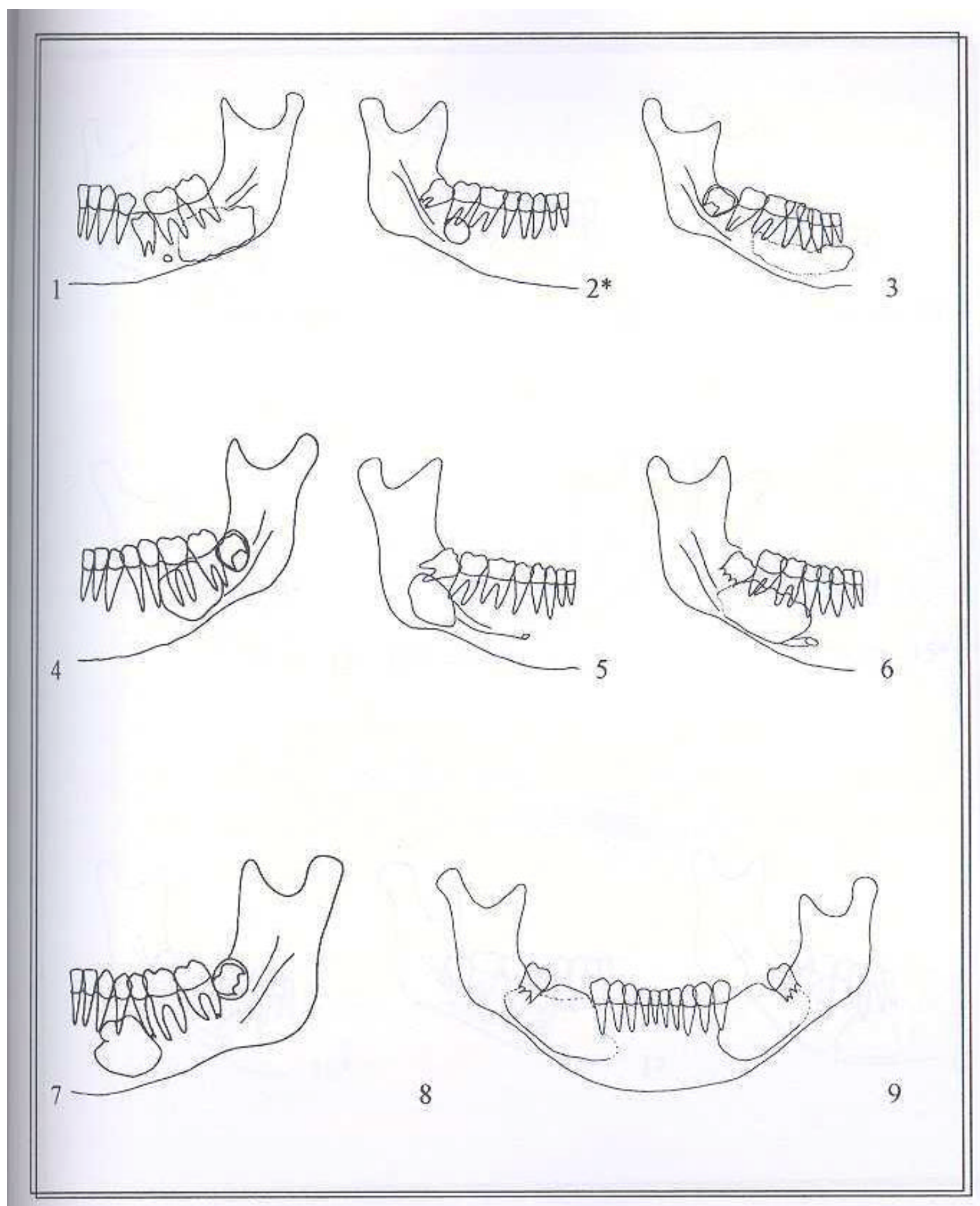

FIGURA 5.9 - Representação esquemática das radiografias de diagnóstico dos casos de cisto ósseo traumático, segundo a localização, tamanho e conformação da lesão.

* Casos compatíveis; $=$ limites definidos; $=$ limites indefinidos 


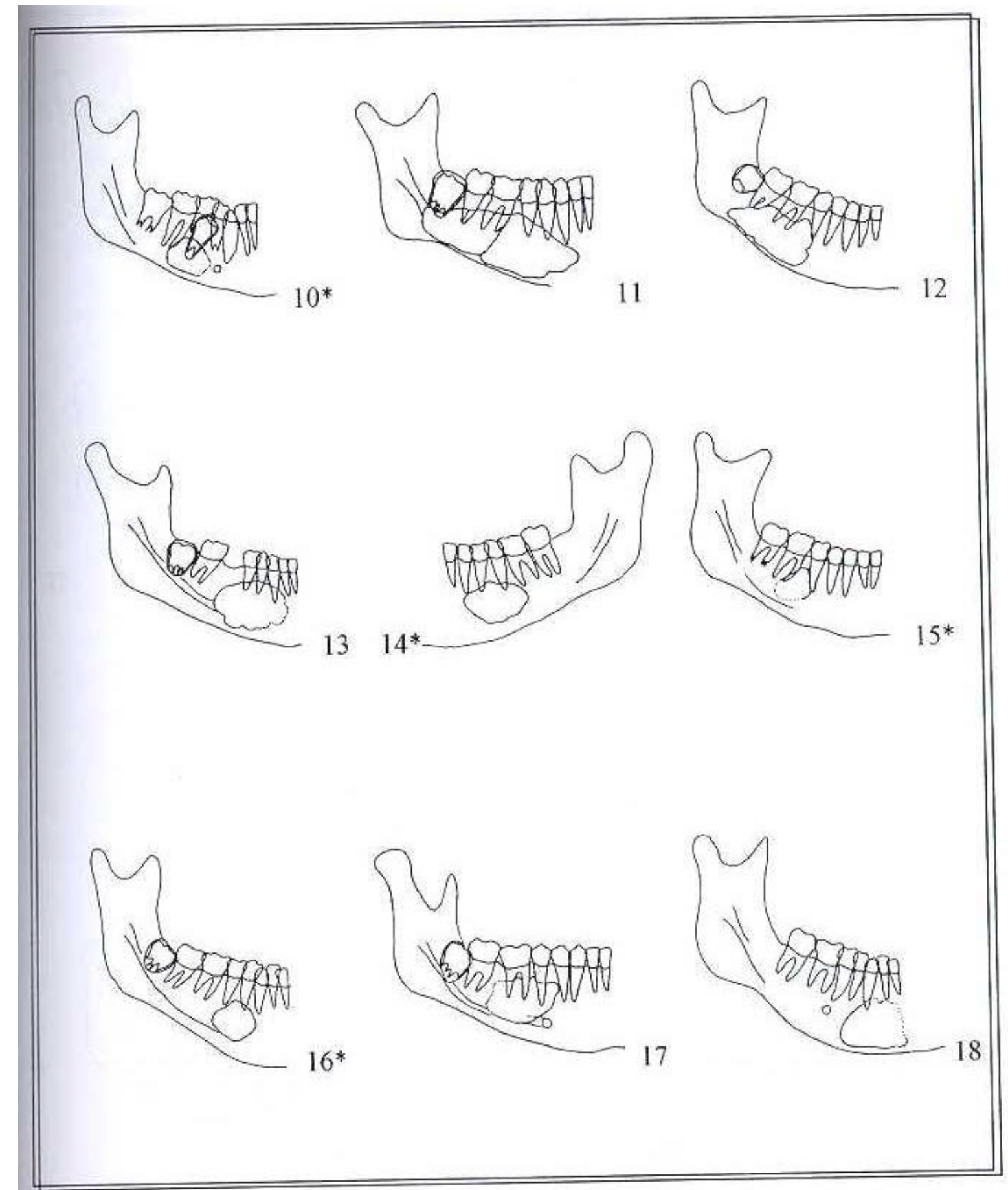

FIGURA 5.10 Representação esquemática das radiografias de diagnóstico dos casos de cisto ósseo traumático, segundo a localização, tamanho e conformação da lesão.

* Casos compatíveis; $=$ limites definidos; $=$ limites indefinidos 

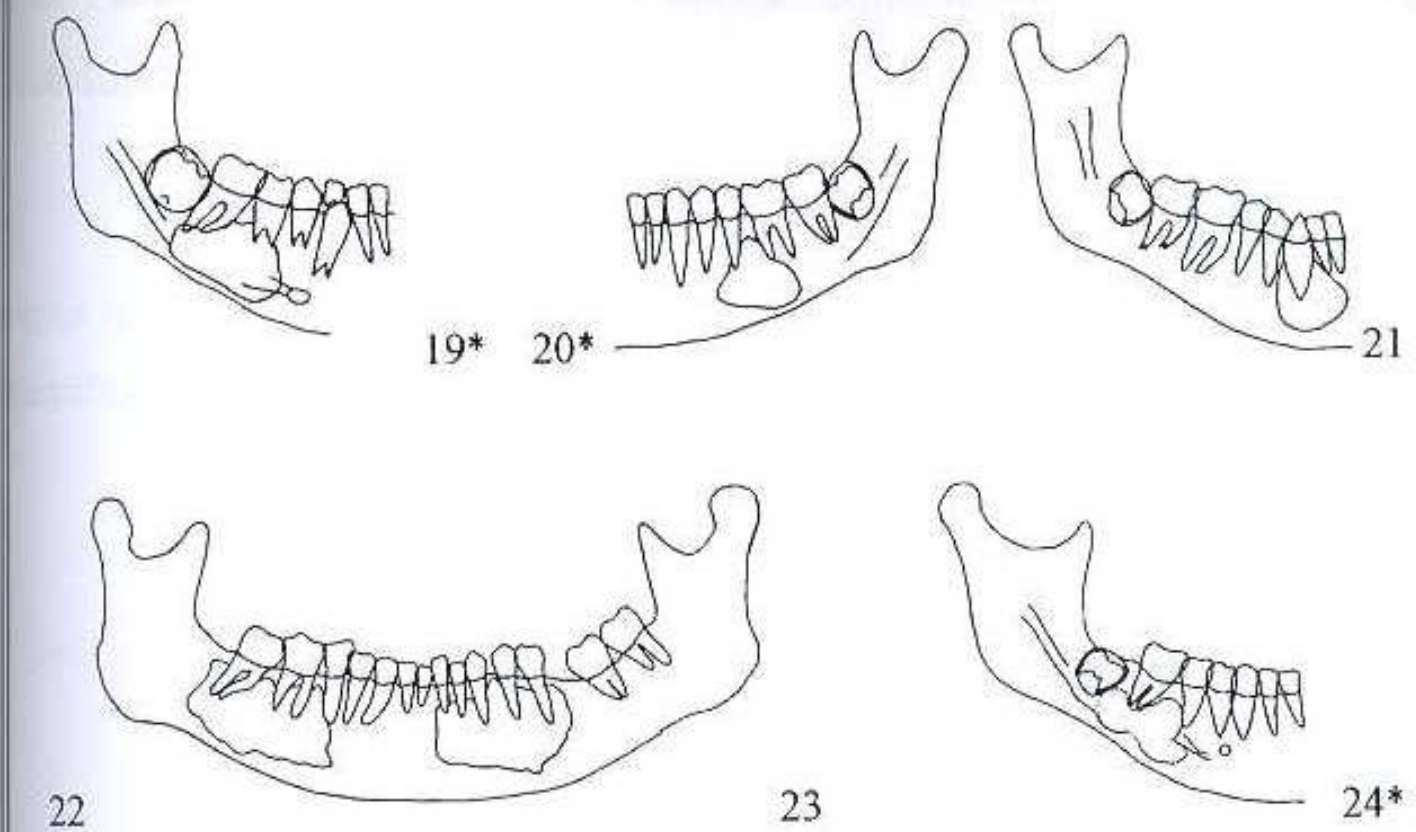

23
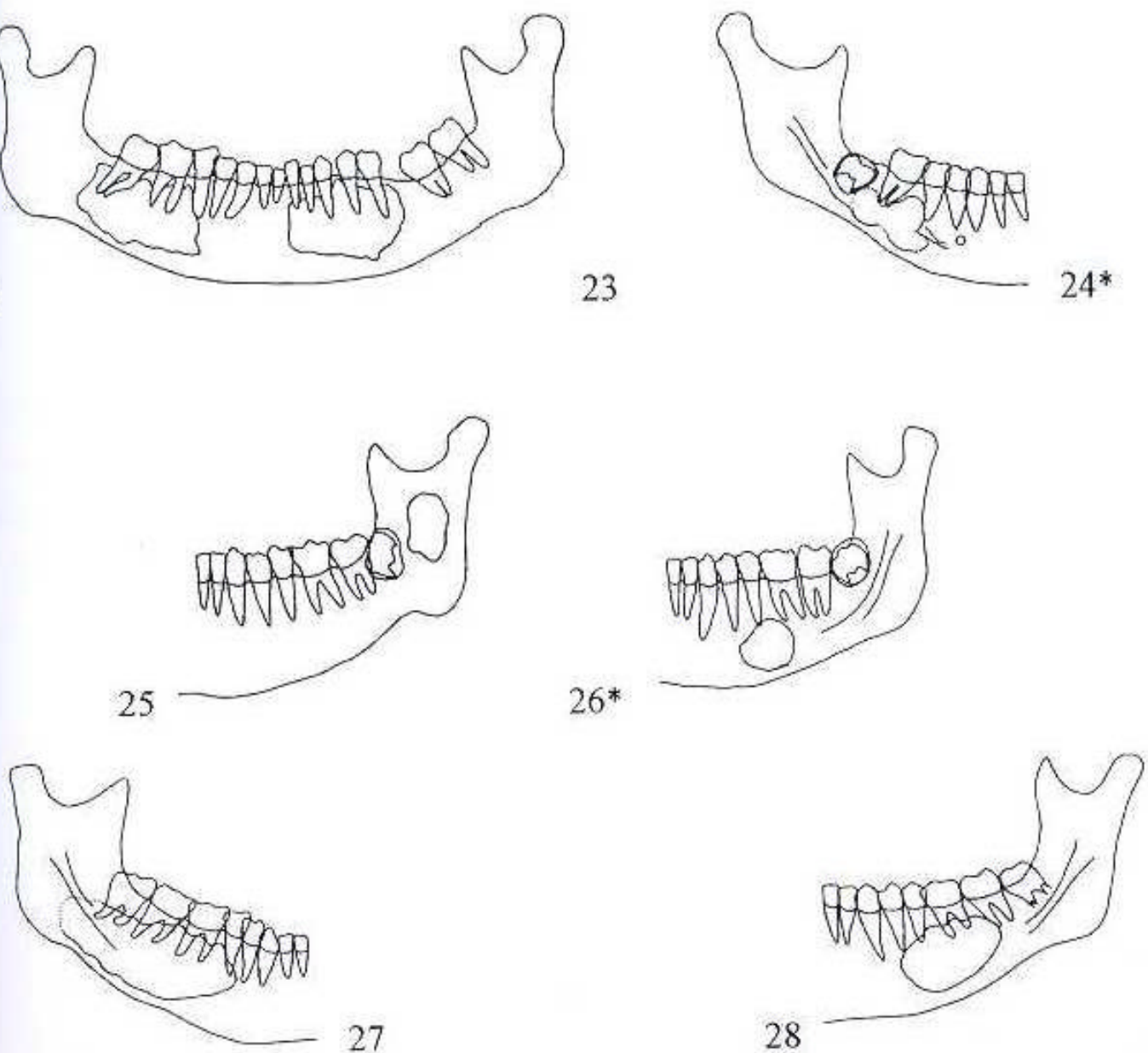

FIGURA 5.11 Representação esquemática das radiografias de diagnóstico dos casos de cisto ósseo traumático, segundo a localização, tamanho e conformação da lesão.

${ }^{*}$ Casos compatíveis; $=$ limites definidos; $=$ limites indefinidos 
5.1.3 Proservação dos casos clínicos compatíveis com cisto ósseo traumático

Os resultados da proservação dos casos clínicos compatíveis da amostra número 1 referentes ao tempo de controle do paciente, estado atual da imagem radiográfica e sintomatologia estão apresentados na Tabela 5.9. 
TABELA 5.9 - Distribuição dos casos clínicos compatíveis da amostra número 1, quanto ao tempo de proservação, estado atual da imagem radiográfica e sintomatologia

\begin{tabular}{|c|c|c|c|c|}
\hline \multirow[t]{2}{*}{$\begin{array}{c}\text { Casos clínicos } \\
\text { compatíveis }\end{array}$} & \multirow[t]{2}{*}{$\begin{array}{c}\text { Tempo de } \\
\text { proservação }\end{array}$} & \multicolumn{2}{|c|}{$\begin{array}{c}\text { Estado atual da imagem } \\
\text { radiográfica }\end{array}$} & \multirow[t]{2}{*}{$\begin{array}{l}\text { Ausência de } \\
\text { sintomatologia }\end{array}$} \\
\hline & & estática & em regressão & \\
\hline Caso 2 & 9 meses & $\bar{X}$ & & $x$ \\
\hline Caso 10 & 3 anos e 6 meses & & $X$ & $X$ \\
\hline Caso 14 & 3 meses & $X$ & & $X$ \\
\hline Caso 15 & 1 ano e 3 meses & $X$ & & $X$ \\
\hline Caso 16 & 6 meses & $X$ & & $X$ \\
\hline Caso 19 & 2 anos e 6 meses & & $X$ & $X$ \\
\hline Caso 20 & 1 ano e 6 meses & $X$ & & $X$ \\
\hline Caso 24 & 2 anos e 6 meses & & $X$ & $X$ \\
\hline Caso 26 & 1 ano e 6 meses & $X$ & & $X$ \\
\hline
\end{tabular}




\subsection{Resultados da amostra número 2}

A epidemiologia do cisto ósseo traumático entre os 956 pacientes com tratamento ortodôntico concluído, está expressa nas Tabelas 5.10, 5.11 e na Figura 5.12 
TABELA 5.10 - Distribuição de 956 pacientes com tratamento ortodôntico concluído, quanto à faixa etária, detectada no início do tratamento ortodôntico

\begin{tabular}{ccc}
\hline \hline $\begin{array}{c}\text { FAIXAS ETÁRIAS } \\
\text { (anos) }\end{array}$ & \multicolumn{2}{c}{ No DE PACIENTES } \\
\hline \hline $5-10$ & 46 & $\%$ \\
$11-15$ & 791 & 4,81 \\
$16-20$ & 94 & 82,74 \\
$21-25$ & 19 & 9,83 \\
$26-30$ & 5 & 1,99 \\
mais de 30 & 1 & 0,53 \\
\hline Total & 956 & 0,10 \\
\hline \hline
\end{tabular}

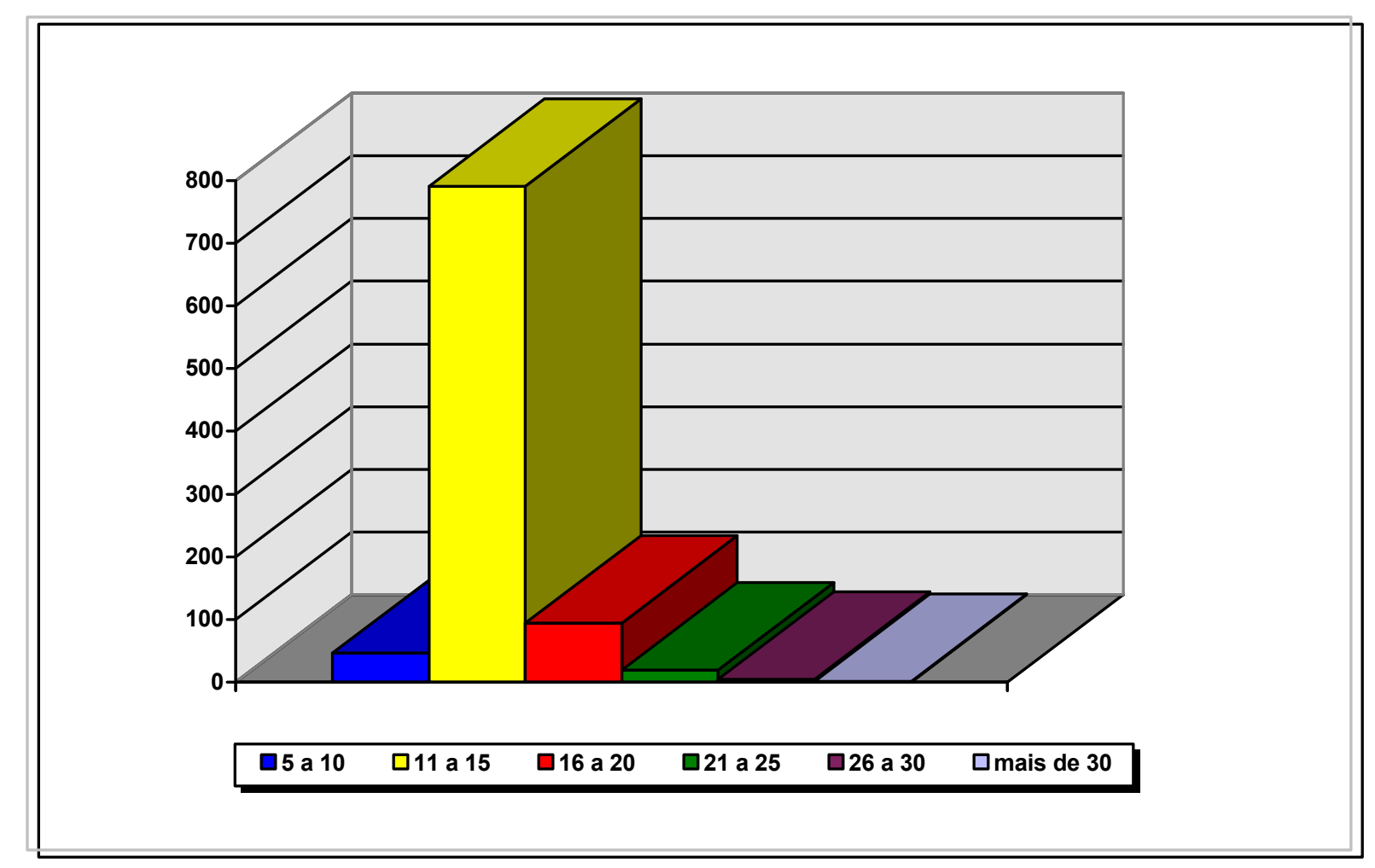

FIGURA 5.12 - Distribuição de 956 pacientes com tratamento ortodôntico concluído, quanto à faixa etária, detectada no início do tratamento ortodôntico 
TABELA 5.11 - Momento em que foi detectada a imagem radiográfica compatível com cisto ósseo traumático em relação à etapa do tratamento ortodôntico: Estudo de oito cistos levantados, entre 956 pacientes com tratamento ortodôntico concluído

\begin{tabular}{|c|c|c|c|}
\hline \multirow[t]{2}{*}{ CASOS* } & \multicolumn{3}{|c|}{ Etapas do tratamento ortodôntico } \\
\hline & Antes** & Durante & Após \\
\hline 1 & $\bar{X}$ & & \\
\hline 2 & & $X$ & \\
\hline 3 & $X$ & & \\
\hline 4 & $X$ & & \\
\hline 5 & & $X$ & \\
\hline 6 & & & $X$ \\
\hline 7 \# & $\mathbf{X}$ & & \\
\hline 8 \# & & & $X$ \\
\hline
\end{tabular}

* Casos com proservação mínima de 2 anos

** Documentação ortodôntica inicial

\# Casos explorados cirurgicamente, incorporados àamostra número 1 


\subsection{Amostras número 1 e 2 relacionadas com tratamento ortodôntico}

A Tabela 5.12 e a Figura 5.13 ilustram o somatório de casos de cisto ósseo traumático envolvidos com o tratamento ortodôntico (amostras número 1 e 2), relacionando-os com a etapa do tratamento ortodôntico em que foram diagnosticados. 
TABELA 5.12 - Distribuição do somatório dos casos da amostra número 1 e 2 envolvidos com o tratamento ortodôntico e sua relação com o momento do diagnóstico

\begin{tabular}{ccc}
\hline \hline MOMENTO DO & \multicolumn{2}{c}{ No DE PACIENTES } \\
DIAGNÓSTICO & $\mathbf{N}$ & $\%$ \\
\hline \hline antes* $^{*}$ & 12 & 50 \\
durante & 8 & 33,33 \\
após & 4 & 16,66 \\
\hline Total & 24 & 100 \\
\hline \hline
\end{tabular}

*Em documentação ortodôntica inicial

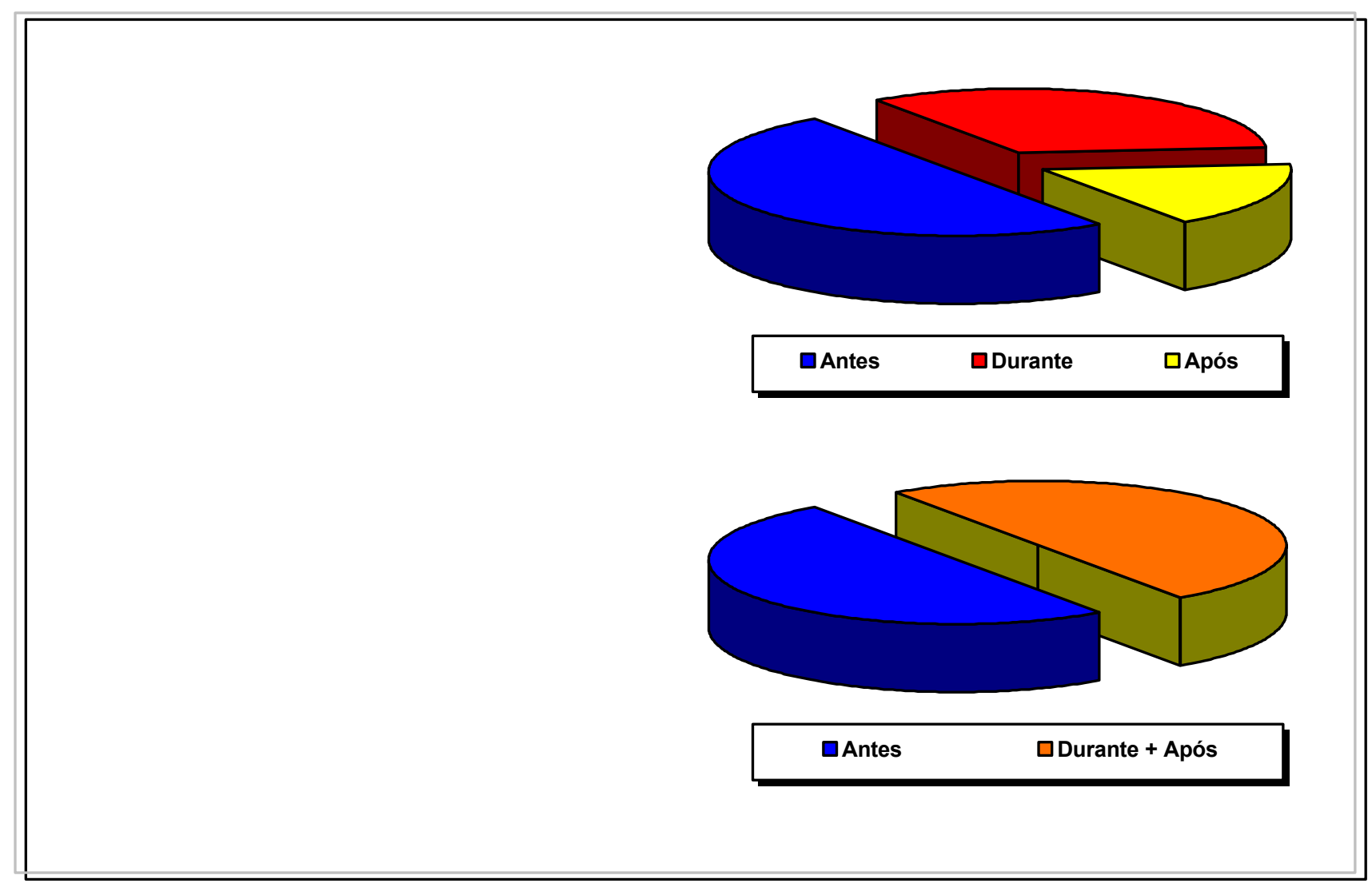

FIGURA 5.13 - Distribuição do somatório dos casos da amostra número 1 e 2 envolvidos com 0 tratamento ortodôntico e sua relação com o momento do diagnóstico 
$\underline{6-\text { DISCUSSÃO }}$ 


\section{DISCUSSÃO}

\subsection{Considerações gerais}

A criação de um grande número de Universidades e cursos de Odontologia no país, com conseqüente formação de mais profissionais e redução dos custos, tem permitido um maior acesso da população ao tratamento odontológico, em especial o ortodôntico. Na realização de um tratamento adequado, o profissional solicita ao paciente um exame radiográfico, fornecendo assim uma maior oportunidade de diagnósticos. Lesões deficientes em sintomatologia, anteriormente julgadas raras pela dificuldade de acesso a exames complementares, passaram a ser mais freqüentemente observadas. As documentações permitiram um check-up radiográfico de crianças e adolescentes, antes pouco realizado. Assim, doenças anteriormente pouco estudadas voltaram àdiscussão com tendências àmelhora de sua compreensão e benefícios para 0 doente.

O interesse do Departamento de Estomatologia da FOB/USP em estudar profundamente o cisto ósseo traumático resultou de alguns fatores, a serem mencionados:

- O aparecimento desta lesão nos exames radiográficos de rotina e como parte de documentação ortodôntica realizados no Departamento;

- O freqüente encaminhamento de pacientes por ortodontistas questionando sobre o diagnóstico, comportamento, tratamento e oportunidade do tratamento ortodôntico; 
- A constante vivência dos problemas, inerentes aos aspectos do diagnóstico clínico, radiográfico e do tratamento do cisto ósseo traumático, objetivando sanar as dúvidas existentes, propiciando um atendimento seguro e, se possível, incruento.

\subsection{Considerações referentes àterminologia e etiopatogenia}

Inicialmente, notou-se neste estudo, a variabilidade quanto à terminologia da doença, como demonstrado na Tabela 2.1 do capítulo de revisão da literatura. 0 termo mais freqüentemente utilizado foi cisto ósseo traumático, apesar de não ser aceito em todos os trabalhos mencionados. $O$ consenso é geral para a utilização do termo "cisto", especialmente após SHEAR ${ }^{112}$ excluir a necessidade de revestimento epitelial para se caracterizar uma cavidade patológica como tal.

A princípio, o termo cisto ósseo traumático não pareceu o mais apropriado, pois vários trabalhos $61,104,107,130,132$ excluíram o trauma como provável agente etiológico na formação da lesão. Chamá-lo de "cisto ósseo solitário" ou "cisto ósseo simples" também não seria o mais correto, uma vez que este cisto pode ocorrer bilateralmente na mandíbula e/ou estar associado a outras lesões ósseas, como mostrado neste trabalho (Tabela e Figura 5.1) e em outros relatos da literatura $17,26,29,31,44,45,49,50,54,60,61,71,73,74,77,99,106,110,117,126,127$. Alguns autores ${ }^{16,45,101,132}$ optaram pelo termo "idiopático", porém, seria muito cômodo denominar todas as doenças que apresentam etiopatogenia desconhecida como idiopáticas. O termo "hemorrágico" é restrito apenas aos casos em que ocorreu derramamento de sangue, fato que, também não é perfeitamente comprovado. 
Neste trabalho, optou-se pela terminologia "cisto ósseo traumático", por três motivos. Primeiro pelo maior número de citações, preferindo chamá-lo assim àoutra denominação nova ou menos freqüentemente descrita. Segundo, porque uma nova denominação viria confundir ainda mais, dificultando a divulgação de suas características. Além disso, trata-se de uma denominação aceita pela OMS ${ }^{64}$. 0 terceiro motivo que justifica o uso do termo "traumático" é a maior abrangência desta terminologia, já que, traumático, do grego "traumatikós" designa uma lesão de extensão, intensidade e gravidade variáveis, que pode ser produzida por agentes diversos (físicos, químicos, psíquicos, etc.), de forma acidental ou intencional, instantânea ou prolongada, em que o poder do agente agressor supera a resistência encontrada ${ }^{27}$. Como no trabalho, está sendo discutida uma possível relação com o tratamento ortodôntico e também a associação com a displasia cementóssea florida, houve por bem entende-lo como uma lesão reacional em resposta a alguma agressão ou estímulo que funcionou como agente irritante. 0 termo "cisto ósseo traumático" pareceu pois, o mais compatível. Vale dizer, que a etiopatogenia do cisto ósseo traumático permanece desconhecida, apesar das inúmeras hipóteses levantadas. Assim, não se propõe nenhuma hipótese nova, mas enfatiza-se a crença na possibilidade de uma resposta "irritativa" do tecido ósseo a algo que o agride. Reforça-se a opinião proposta por HANSEN43, em 1974, para a necessidade de um relato claro, completo e detalhado dos casos, sendo este o único meio capaz de solucionar o problema inerente àetiopatogenia.

A seguir, passaremos àanálise dos resultados. 


\subsection{Relação entre o cisto ósseo traumático e o gênero, a raça e a faixa etária da amostra número 1.}

A observação da Tabela e da Figura 5.1, nas quais se relaciona a freqüência do cisto ósseo traumático com o gênero, mostra que houve uma freqüência semelhante. Os trabalhos de GARDNER et al. ${ }^{37}$, HUEBNER; TURLINGTON54 e BEASLEY 5 mostraram uma predileção pelo gênero masculino, já os casos relatados por ZEGARELLI et al. ${ }^{132}$, HANSEN et al. ${ }^{43}$ e KAUGARS; CALE61 não demonstraram diferenças significantes entre os gêneros. Um dado interessante que deve ser ressaltado na Tabela 5.1 é a ocorrência de dois casos bilaterais em pacientes do gênero feminino, um deles associado à displasia cementóssea florida. Este resultado vai ao encontro daqueles encontrados na literatura, como por exemplo, os 17 casos de cisto ósseo traumático associados àdisplasia óssea florida relatados por MELROSE et al. ${ }^{74}$, afetando 14 pacientes do gênero feminino. KAUGARS; CALE61 na análise de 161 casos enfatizaram a presença de lesões múltiplas em mulheres, reforçando que a associação com a displasia cementóssea florida aumenta a freqüência de cisto ósseo traumático neste gênero. Vale enfatizar que a maioria dos casos de lesões múltiplas relatados na literatura ocorreu em mulheres $26,45,49,61,71,74,77,99,106,127$.

A Tabela e a Figura 5.2 revelam uma maior ocorrência do cisto ósseo traumático nos pacientes da raça branca. Apesar da classificação das lesões entre as diferentes raças ser um pouco subjetiva, principalmente no Brasil devido à miscigenação, além da predominância da população branca em vários países, os trabalhos são unânimes em relatar o maior número de casos em brancos. Fazem exceção os casos associados à displasia cementóssea florida ou apresentando lesões múltiplas, os quais ocorrem predominantemente em negros. A Tabela e a Figura 5.2 
também mostram a ocorrência de dois cistos bilaterais em pacientes da raça negra, em acordo ao trabalho de KAUGARS; CALE ${ }^{61}$ que mostra a maior incidência do cisto em jovens brancos, mas relata casos em adultos negros do gênero feminino. A displasia cementóssea florida é uma doença de prevalência marcante em mulheres negras. Conforme já se mencionou, anteriormente, o cisto ósseo traumático pode ser uma lesão reacional, aparecendo nestas circunstâncias como uma resposta à irritação do osso, provocada pela displasia cementóssea florida ${ }^{49,74}$.

A predominância do cisto ósseo traumático em pacientes na segunda década de vida pode ser nitidamente observada na Tabela e na Figura 5.3, com 22 pacientes, somando-se os valores de 11 a15 e de 16 a 20 anos. A literatura é enfática quanto à maior ocorrência do cisto ósseo traumático em pacientes jovens, predominantemente na segunda década de vida10,11,37,43,54,79,86,130,132. Os casos associados à displasia cementóssea florida fogem à regra, nestes casos a média de idade varia entre 30 e 50 anos $45,49,74,77,127$. A paciente deste trabalho que apresentava a associação do cisto ósseo traumático com a displasia cementóssea florida com lesões bilaterais tinha 43 anos de idade. 0 outro caso bilateral descrito neste trabalho era de uma adolescente (15 anos) negra, com a qual perdeu-se o contato e a proservação. Hoje, após tantos anos da data do seu diagnóstico e tratamento não se pode descartar a possibilidade de que ela seja uma portadora de displasia cementóssea florida que na época mostrava o prenúncio de sua manifestação.

Trabalhos mais recentes ${ }^{71,106}$ têm classificado 0 cisto ósseo traumático em dois grupos, um com menos de 30 anos e um com mais de 30 anos de idade. Os casos clínicos classificados entre o grupo com menos de 30 anos apresentaram aspectos típicos, semelhantes àqueles freqüentemente descritos na literatura $5,37,43,52,53,54,61,79,86,100,132$, enquanto os casos pertencentes ao grupo com mais de 
30 anos apresentaram cistos atípicos, havendo associação entre lesões múltiplas, recorrências, gênero feminino e idade mais avançada. Outro dado relevante observado na Tabela 5.3 é a presença de um cisto ósseo traumático típico em uma paciente de 27 anos de idade. Sua imagem, entretanto, mostrava sinais adicionais de reparo ósseo, sugerindo regressão espontânea, por este motivo, não foi submetida à intervenção cirúrgica.

A relação entre a regressão espontânea e a ocorrência do cisto ósseo traumático, em jovens, é abordada pela maioria dos trabalhos existentes na literatura, porém poucos casos são descritos mostrando o fato ou defendendo 0 acompanhamento clínico e radiográfico dos pacientes portadores deste cisto. Essas referências serviram, contudo, como sustentação para a conduta que tem sido adotada no Departamento, induzindo-nos a apresentar à literatura um sistema incruento de diagnóstico e proservação, principalmente nos casos em que o paciente for capaz de atender a um controle clínico e radiográfico, em intervalos periódicos.

\subsection{Relação entre o cisto ósseo traumático e a história de trauma e/ou de tratamento ortodôntico, na amostra número 1}

A relação entre o cisto ósseo traumático e a história de trauma tem sido abordada há muitos anos $5,10,11,37,43,53,57,61,79,86,132$ pois está implicada numa das hipóteses da sua etiopatogenia. Uma história positiva de trauma estava presente em $30,77 \%$ dos pacientes, como representado na Tabela e na Figura 5.4. Este resultado foi semelhante àqueles relatados na literatura, com $25 \%$ de história de trauma no trabalho de GARDNER et al. ${ }^{37} ; 35,3 \%$ nos casos de ZEGARELLI et al. ${ }^{132} ; 27,8 \%$ relatado por MORRIS et al. ${ }^{79} ; 26,9 \%$ por BEASLEY5 e 35,3\% por KAUGARS; CALE ${ }^{61}$. Porém, estes 
resultados não parecem relevantes, pois MORRIS et al..$^{79}$ analisaram a freqüência da história de trauma em um grupo controle que não apresentava cisto ósseo traumático e encontraram uma resposta positiva em $25 \%$ desta população. KAUGARS; CALE ${ }^{61}$ também relataram que a história de trauma relacionada ao cisto ósseo traumático é similar àhistória de trauma na população em geral. SHEAR ${ }^{112}$, por outro lado, argumenta contra a teoria traumática na formação do cisto, devido ao fato das dificuldades em se estabelecer uma história, alegando a possível relação com algum outro estímulo.

A relação entre o cisto ósseo traumático e a história de tratamento ortodôntico, apesar de não abordada na literatura, exceto o relato de casos em que o diagnóstico foi realizado antes ou durante 0 tratamento 14,32,130, foi abordada neste trabalho, devido à alta freqüência de observação deste fato na rotina clínica. Os resultados mostram que $18(69,23 \%)$ pacientes da amostra número 1 apresentavam história de tratamento ortodôntico, como observado na Tabela e na Figura 5.4. Este resultado nos fez sugerir duas hipóteses: a primeira seria a provável relação da movimentação dentária na etiopatogenia do cisto ósseo traumático. A segunda seria a sistematização da documentação ortodôntica, a razão da detecção dessa doença assintomática.

A observação da Tabela e da Figura 5.5 mostra que dos 18 pacientes com história de tratamento ortodôntico, nove (50\%) foram encontrados antes do tratamento , ou seja, na documentação ortodôntica inicial. Os outros nove foram detectados durante ou após o tratamento. Levando em consideração os casos diagnosticados antes da movimentação dentária, a primeira hipótese seria descartada, mas considerando-se os outros nove, diagnosticados durante ou após o tratamento ortodôntico, esta hipótese poderia ser levantada. Porém, os três casos que ocorreram após o tratamento ortodôntico podem não ter sido imediatos ao final do tratamento. 
Assim, a alta prevalência do cisto ósseo traumático em pacientes com história de tratamento ortodôntico (Tabelas 5.4 e 5.11 e Figura 5.4) parece mostrar apenas uma coincidência de situações. Dessa discussão e à luz dos resultados, depreende-se, entretanto, uma inferência de alto valor clínico: 0 ortodontista tem grande responsabilidade no diagnóstico do cisto ósseo traumático, pois, quase sempre é o primeiro profissional a entrar em contato com a lesão. Deve-se considerar para isto, que em alguns países de primeiro mundo a Radiologia não é especialidade e, mesmo no Brasil, existem muitos ortodontistas que fazem a documentação radiográfica dos seus pacientes.

\subsection{Diagnóstico do cisto ósseo traumático segundo o tipo de radiografia examinada}

O diagnóstico completo e seguro de determinadas doenças dos maxilares requer, além do exame clínico detalhado, um exame radiográfico composto por radiografias panorâmica, periapical e oclusal. Na Tabela e na Figura 5.6, pode-se observar que este fato não ocorreu, havendo uma grande discrepância entre a quantidade de radiografias panorâmicas realizadas, em 100\% dos casos, e de radiografias periapicais $(57,14 \%)$ e oclusais $(42,85 \%)$.

A maior freqüência de radiografias panorâmicas parece óbvia pois, serve à triagem populacional para interpretação geral do estado odontológico do paciente e tem baixo custo em relação à demais. A discrepância na documentação radiográfica se prende a uma forte razão. Os casos que foram oferecidos por cirurgiões bucomaxilofaciais possuem apenas radiografias panorâmicas e foram explorados cirurgicamente, apenas por esta orientação radiográfica. Muitos cirurgiões operam sem 
se firmarem num diagnóstico presuntivo, tentando buscar material para exame, na expectativa de que o diagnóstico final seja dado pelo patologista. No caso do cisto ósseo traumático, porém, quase sempre nenhum material é colhido, apenas é detectada uma cavidade vazia (Figura 4.4), sendo o diagnóstico final apenas cirúrgico. Para colher material da parede cística e detectar a fina membrana conjuntiva relatada por alguns autores 5,10,31,43,54,61,74,79,106,112,129,132, há que se planejar o acesso cirúrgico e a tábua óssea deverá ser desmineralizada. O exame clínico e radiográfico detalhado poderá afastar a necessidade de exploração cirúrgica para a realização do diagnóstico final, como relatado em alguns trabalhos $21,71,106,112,117$.

Os casos documentados com radiografias oclusais e periapicais são quase todos da FOB/USP, onde a formação mais acadêmica dos profissionais envolvidos é a responsável por tal fato. Princípios clássicos dos métodos de localização radiográfica, além dos sinais radiográficos da doença quanto à relação com as raízes dentárias e não expansão das corticais ósseas referidas pela literatura $31,43,79,86,107,132$ garantem a necessidade do exame completo para a segurança do diagnóstico presuntivo. Há que se destacar este fato pela pobreza de sinais clínicos e histopatológicos dessa doença.

\subsection{Epidemiologia do cisto ósseo traumático, segundo localização e conformação da imagem radiográfica}

A mandíbula é sem dúvida o sítio preferencial de localização do cisto ósseo traumático, como mostrado na Tabela e na Figura 5.7, em 100\% dos casos. A literatura também é unânime em apontar a mandíbula como sede principal de manifestação deste cisto. Raros casos são relatados na maxila ${ }^{43,99,131}$ e um único caso 
foi descrito no osso zigomático ${ }^{12}$. Quando porém, a maxila é atingida, geralmente 0 cisto está associado à displasia cementóssea florida ${ }^{74}$. HANSEN et al. ${ }^{43}$ relataram que a raridade do cisto ósseo traumático ocorrer na maxila é devido à radiolucência do seio maxilar obscurecer algumas lesões. KAUGARS; CALE ${ }^{61}$ reconhecem esta possibilidade, porém, acham que este fato não explica a grande preferência do cisto pela mandíbula. $A$ incomum ocorrência dentro da maxila pode ser melhor explicada pela sua relativa menor quantidade de osso medular e pela diferença de vascularização em relação à mandíbula61.

A Tabela e a Figura 5.7 mostram uma maior predileção do cisto ósseo traumático pelo corpo mandibular, com 22 casos (78,57\%), destes, surpreendentemente, $50 \%$ ocorreram no corpo mandibular direito. Os outros casos atingiram a sínfise $(7,14 \%)$, a sínfise e corpo $(10,71 \%)$ e um caso ocorreu no ramo ascendente. A região de molares e pré-molares é o principal sítio da lesão, sendo este dado encontrado na maioria dos casos. 0 corpo mandibular direito é relatado em alguns trabalhos como a localização de maior prevalência, mas este dado não é enfatizado pela literatura e explicações coerentes não foram fornecidas para 0 fato. HUEBNER; TURLINGTON 54 encontraram $41,74 \%$ dos casos na região posterior da mandíbula à direita e 30,09\% dos casos à esquerda, os autores chamaram a atenção para esta ocorrência, mas sem justificativas. Entretanto, HANSEN et al. ${ }^{43}$ relataram não haver predileção por lado na mandíbula. Quanto àmaior freqüência na mandíbula, parece um problema exclusivamente ligado ao osso medular e àirrigação sangüínea própria deste osso. 
Os resultados obtidos a partir da análise da conformação do cisto ósseo traumático podem ser observados na Tabela 5.8 e nas Figuras 5.8, 5.9, 5.10 e 5.11. A lesão mostrou-se freqüentemente como uma radiolucência oval unilocular em $82,14 \%$ dos casos. Em quatro casos era redonda e unilocular, e num único caso seu aspecto foi multilocular (caso 11 da Figura 5.10). Este padrão de imagem encontrado nestes resultados é aquele também comumente relatado na literatura, sendo a forma oval unilocular 0 aspecto mais característico do cisto ósseo

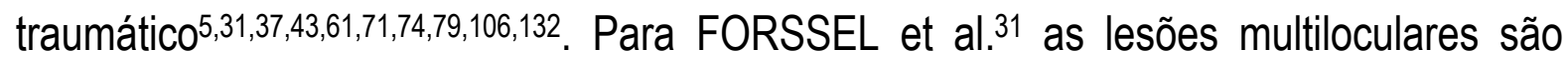
raras e quando aparecem causam dificuldades no diagnóstico pré-operatório. Pela sua raridade, parece um fenômeno de menor importância embora deva ser conhecido pelos profissionais.

As Figuras 5.9, 5.10 e 5.11 mostram os esquemas confeccionados a partir de um traçado das radiografias panorâmicas originais de diagnóstico dos 28 casos de cisto ósseo traumático da amostra número 1, segundo a localização, tamanho e conformação da imagem. Estas Figuras demonstram que todos os cistos ocorreram na mandíbula, predominantemente na região de pré-molares e molares, como discutido anteriormente, contudo deve-se enfatizar, que nenhum caso ultrapassou a linha média, estando contido em apenas um hemiarco. Dois casos foram bilaterais (casos 8 e 9 e 22 e 23 das Figuras 5.9 e 5.11, respectivamente), sendo 0 caso 22-23 associado àdisplasia cementóssea florida. 


\subsection{Critérios de diagnóstico e proservação dos casos clínicos compatíveis com cisto ósseo traumático da amostra número 1}

Em nove casos, o diagnóstico do cisto ósseo traumático foi apenas radiográfico e clínico. Para isso levou-se em consideração os mesmos critérios clínicos e radiográficos observados no diagnóstico dos demais casos desta amostra número 1 , que tiveram confirmação cirúrgica.

Há alguns anos tem se evitado a abordagem cruenta em alguns casos clínicos compatíveis com cisto ósseo traumático no Departamento de Estomatologia da FOB/USP. Isto se deve a algumas razões: A primeira é a constatação de curas espontâneas pela literatura, já relatadas por SZERLIP117, desde 1966, e por SAPP; STARK ${ }^{107}$, em 1990. A segunda razão é a vivência clínica dos profissionais do Departamento de Estomatologia no tratamento pelo método cruento, no qual é inevitável o trauma cirúrgico pela osteotomia de corticais quase sempre íntegras, levando a um pós-operatório, muitas vezes desagradável. Soma-se a isto, o risco de lesar estruturas nobres como o feixe vasculonervoso das raízes dentárias e até o alveolar inferior, numa tentativa frustrada de colher material para o exame microscópico. A terceira razão é a preferência do paciente pelo método incruento, responsabilizando-se pela obediência ao protocolo de complementação de diagnóstico e proservação. $O$ fato de crianças ou adolescentes no início da segunda década (11 a 15 anos) serem predominantemente atingidas (Tabela e Figura 5.3) também tem justificado o método incruento aplicado a estes pacientes. Até mesmo o tamanho da lesão não justificaria a abordagem cirúrgica com o objetivo de se conseguir o reparo ósseo imediato, pois as áreas de reforço ósseo estão quase sempre íntegras, sendo improvável a ocorrência de fratura patológica. 
Assegurar de que não se trata de outra doença constitui preocupação inicial da aplicação do protocolo, já que áreas osteolíticas têm uma multiplicidade de diagnósticos microscópicos prováveis. Entretanto, áreas osteolíticas não caracterizam necessariamente neoplasia maligna, além do que existem doenças, nas quais a aparência radiográfica e o comportamento clínico determinam o diagnóstico final. Basta questionar o porquê de não se indicar biópsia no diagnóstico da displasia cementária periapical ou no defeito ósseo de Stafne, os quais são condições semelhantes æ̀ do cisto ósseo traumático, sendo os exames clínicos, radiográficos e a proservação determinantes do diagnóstico. Além disso, vale ressaltar que, no caso do cisto ósseo traumático, o material para exame microscópico, na maioria das vezes não é obtido, como ocorreu em quase todos os casos desta amostra tratados cirurgicamente. Podendo-se pois, evitar o diagnóstico cirúrgico, com o uso de critérios clínicos e radiográficos bem fundamentados, certamente estaremos indo ao encontro do desejo e da expectativa dos doentes.

Assim, passaremos a discutir abaixo os critérios de diagnóstico e proservação:

1 - Exame clínico e radiográfico 20 dias após a descoberta da lesão, sem sintomatologia constatável e com imagem radiográfica estável e comparável àimagem de diagnóstico. 0 objetivo primeiro deste exame é eliminar a possibilidade de doença maligna, pois neste caso, em 20 dias alguma modificação clínica e radiográfica ocorreria no local ou em outras áreas dos maxilares. Este período (20 dias) é considerado um parâmetro clínico para diferenciação de malignidade e benignidade. Um exemplo desta situação seria o comportamento de um linfoma.

2 - Exame clínico e radiográfico de 60 dias mantendo as características iniciais ou com a radiografia mostrando involução da lesão. Como a doença é assintomática, ao se detectá-la radiograficamente não se sabe há quanto 
tempo ela já existia pois, a história de trauma nem sempre está presente ou é lembrada pelo paciente (Tabela e Figura 5.4), fato este enfatizado na literatura5, 10,11,37,43,53,57,61,79,86,132. Com duas seqüências de exames aos 20 dias e aos 60 dias pode-se observar a estabilidade ou não da lesão, pela ausência de sinais clínicos e imagem estável ou em regressão. Se isto for obtido, já está reforçado, o diagnóstico definitivo. Se o contrário advir, ou seja, expansão da imagem ou aparecimento de sintomas ou sinais clínicos, indica-se a imediata abordagem cirúrgica. Até hoje nunca se presenciou o processo evolutivo de um cisto ósseo traumático que certamente esclareceria tantas indagações e inquietações sobre a patogenia e comportamento biológico desta doença.

3 - Exame clínico e radiográfico de seis meses mantendo as características iniciais ou de involução da lesão. Com seis meses de estabilidade ou involução dos sinais radiográficos e "silêncio" de sintomatologia já consideramos cisto ósseo traumático como diagnóstico definitivo.

4 - Controle de um ano ou mais, repetindo-se os aspectos já mencionados. Estes controles subseqüentes têm apenas o objetivo de se acompanhar 0 reparo espontâneo da área.

$\mathrm{Na}$ aplicação prática destes critérios, o profissional deve levar em consideração pequenas modificações na amplitude e na conformação da imagem, não se esquecendo que a lesão poderá estar se instalando ou o paciente crescendo. 0 bom senso deve prevalecer pois a subjetividade é inerente ao diagnóstico.

0 seguimento deste protocolo de complementação de diagnóstico e de proservação em nove casos da amostra número 1 considerados compatíveis com cisto ósseo traumático, forneceu os resultados observados na Tabela 5.9 , mostrando que em seis casos as lesões permaneceram estáveis e em três casos as 
lesões estão em regressão. Na Tabela 5.9, também se pode observar que estes casos em involução são os que apresentam um maior tempo de proservação. Estes dados estão de acordo com aqueles relatados por SAPP; STARK ${ }^{107}$, nos quais o período de tempo entre o diagnóstico e o reparo completo da lesão variou de dois anos e nove meses a sete anos e cinco meses, dependendo da idade do paciente no momento do diagnóstico. Não se deve esperar resultados em curto espaço de tempo. 0 crescimento esquelético e a função é que reestruturam o osso. A sua reestruturação não é como em um processo de reparo de ferida.

\subsection{Relação entre o cisto ósseo traumático e o tratamento ortodôntico}

A possível implicação do tratamento ortodôntico na etiopatogenia do cisto ósseo traumático ainda não foi abordada na literatura, apenas relataram casos clínicos, nos quais o diagnóstico foi realizado antes, durante ou após 0 tratamento ortodôntico ${ }^{14,32,130 .}$

\subsubsection{Relação epidemiológica}

No afã de verificar especificamente a epidemiologia do cisto ósseo traumático entre pacientes com tratamento ortodôntico examinou-se os prontuários de 956 indivíduos com tratamento concluído. A Tabela 5.10 e a Figura 5.12 ilustram a distribuição dessa amostra segundo a faixa etária. Como eram pacientes de Ortodontia corretiva já se esperava, em função da idade ideal para o tratamento ortodôntico, que a grande concentração dos pacientes seria na segunda década da vida, com destaque a faixa dos 10 aos 15 anos, à semelhança do que ocorre com o cisto ósseo traumático (Tabela e Figura 5.3). 
Interpretando as radiográficas panorâmicas e as fichas clínicas de diagnóstico e evolução de tratamento de todos os pacientes, encontrou-se oito casos compatíveis com o diagnóstico de cisto ósseo traumático.

A inexistência de intercorrências clínicas durante o tratamento ortodôntico, baseada na ficha evolutiva dos pacientes caracterizou a inferência do "silêncio" de sintomatologia, próprios da doença. Vale enfatizar, que o material de arquivo da Ortodontia, com mais de 20 anos de duração, é oriundo de cursos de pósgraduação e especialização, nos quais o rigor de metodologia impostos pela Disciplina constitui uma garantia da veracidade do seu conteúdo.

Quanto æ̀s imagens radiográficas, aplicou-se os critérios apresentados na metodologia desta investigação, extraídos de uma vasta literatura baseada em inúmeros estudos epidemiológicos $5,31,37,39,43,52,53,54,61,65,71,79,86,104,106,107,112$, 119,120,132. A observação das imagens radiográficas iniciais compatíveis foi sedimentada nos controles radiográficos anuais que mostravam imagens estáveis. Este estudo foi realizado apenas em radiografias panorâmicas, já que as periapicais e as oclusais não são rotina em Ortodontia para a região de pré-molares e molares inferiores, áreas de maior incidência do cisto ósseo traumático.

Apesar da convicção do diagnóstico clínico e radiográfico das imagens encontradas solicitou-se a opinião de quatro especialistas em Radiologia sobre a compatibilidade das mesmas. A Tabela 4.1 ilustra as opiniões apuradas. Em apenas três situações, dois examinadores responderam como imagem "não compatível", sendo as opiniões coincidentes apenas no caso número 1. Por dois motivos as respostas foram desconsideradas. Primeiro, por não oferecerem outra hipótese de diagnóstico, reação freqüente de quem não está muito convicto, sendo própria da subjetividade envolvida na 
interpretação de imagens. Em segundo lugar, porque os examinadores só opinaram sobre a radiografia de diagnóstico, não tendo a garantia apresentada pela análise das radiografias de controle. Ainda assim, reavaliou-se os casos por eles assinalados, porém não se modificou o diagnóstico. Este só seria modificado, se metade das opiniões entre orientador, autor e examinadores fosse contrária num mesmo paciente.

Os oito casos de cisto ósseo traumático encontrados nessa amostra específica foram apresentados na Tabela 5.11. Ela discrimina o momento em que a imagem radiográfica foi detectada em relação à etapa do tratamento ortodôntico. Dois dos casos apresentados eram relatados nos prontuários pois foram explorados cirurgicamente, já tomando parte na amostra número 1. Ambos tinham as imagens marcantes, daí sua percepção. Os demais passaram despercebidos na rotina do dia-adia da clínica ortodôntica, o que enfatiza a necessidade da participação de radiologistas dividindo com o ortodontista as responsabilidades do diagnóstico radiográfico.

\subsubsection{Relação etiopatogênica}

Sabe-se que o movimento dentário é um produto de eventos biológicos e não do efeito físico, sendo este apenas o elemento indutor inicial. A compressão mecânica gera deformação do citoesqueleto das células do ligamento periodontal. As células deformadas liberam citocinas, fatores de crescimento e produtos do ácido araquidônico, instalando-se, assim, o processo inflamatório necessário à movimentação dentária. Se a força aplicada for ideal ou ótima (15-20 mmHg ou 20-26 $\mathrm{g} / \mathrm{cm}^{2}$ de raiz), ocorrerá a reabsorção óssea frontal e o dente se movimentará. Quando a força aplicada for muito intensa, gerando uma anoxia, os osteoblastos e cementoblastos morrerão, formando uma área hialina espessa, com reabsorção de algumas trabéculas ósseas, induzindo a chamada reabsorção óssea àdistância22,95,97,109. 
Para o dente movimentar-se, na área de pressão os osteoclastos devem ser formados de modo que possam remover o osso da área adjacente à parte comprimida do ligamento periodontal. Também é necessária a formação de osteoblastos para a produção de novo osso no lado de tensão. Os mediadores do processo inflamatório têm a propriedade de estimular tanto a atividade osteoclástica quanto a osteoblástica, sendo portanto mediadores do movimento dentário. Os clastos atacam a lâmina dura adjacente, removendo osso pelo processo de "reabsorção frontal", iniciando-se assim, o movimento dentário. 0 curso dos eventos se torna diferente se a força aplicada contra 0 dente for grande 0 suficiente para ocluir totalmente os vasos sangüíneos e interromper o suprimento sangüíneo para determinada área no ligamento periodontal. Quando isso acontece ocorre uma necrose nesta área, chamada de "hialinizada" por causa de sua aparência microscópica de desaparecimento das células. O mais importante é que os clastos iniciam uma reabsorção óssea nos espaços medulares contíguos ao osso alveolar, denominada de "reabsorção solapante ou à distância". Logicamente, o melhor é evitar este tipo de reabsorção, porém, mesmo com 0 uso de forças leves, pequenas áreas avasculares podem se desenvolver, causando estas inevitáveis áreas de reabsorção22,95,97,109. Entretanto, técnicas contemporâneas têm procurado minimizar os efeitos deletérios do tratamento ortodôntico sobre os tecidos dentários e ósseo. 0 desenvolvimento recente dos fios superelásticos representam um avanço científico para a Ortodontia, com o estabelecimento de novos padrões biológicos no tratamento ortodôntico. Independentemente do grau de ativação, estes fios liberam uma força leve e constante à temperatura bucal, por apresentarem menor força e rigidez ${ }^{76,125}$.

Vizinho à áreas de necrose, o tecido ósseo inflamado poderia sangrar induzido por forças mastigatórias normais sobre uma área doente ou mesmo 
pela continuidade de forças ortodônticas excessivas. As trabéculas de osso esponjoso seriam destruídas, instalando assim, um cisto ósseo traumático.

HOWE ${ }^{53}$ admitiu a possibilidade de uma hemorragia espontânea ocorrer dentro da lesão, tendo o mesmo efeito da intervenção cirúrgica, que leva à reparação. Em outras palavras, o mesmo fator que levaria à formação do cisto ósseo traumático poderia também, levar à sua cura. Especulando sobre o assunto, 0 tratamento ortodôntico, tanto poderia causar o cisto, como ser uma forma de tratamento do mesmo. Falta contudo, comprovação científica. Com base nestes princípios, entretanto, os ortodontistas têm sido por nós orientados a movimentarem os dentes com forças leves e constantes, em casos de cisto ósseo traumático que estão no protocolo de proservação e que, tiveram diagnóstico clínico e radiográfico. Nunca porém, deve-se instituir a aplicação da mecânica ortodôntica antes de seis meses de observação do paciente para confirmação do diagnóstico.

Observando-se os resultados da Tabela 5.12 e da Figura 5.13 percebe-se, entretanto, que o tratamento ortodôntico não parece ser desencadeador do processo, pelo menos na maioria dos casos. Vê-se que $50 \%$ dos casos estudados foram descobertos durante a fase de documentação ortodôntica inicial, ou seja, antes do tratamento. Por outro lado, $16,66 \%$ dos casos tiveram manifestação após a movimentação dentária, podendo não ser dela decorrente. Apenas 33,33\% ocorreram em concomitância e/ou em decorrência do tratamento ortodôntico. Porém, numa análise simplista da Tabela 5.12, na qual 24 pacientes estão de alguma forma envolvidos com a Ortodontia, poderia suspeitar-se da participação dela na etiopatogenia da doença. Vale destacar, por outro lado, que oito casos (Tabela 5.11) foram detectados especificamente numa amostra de 956 casos de pacientes da Disciplina de Ortodontia da FOB/USP, número este grande se comparado à epidemiologia do cisto na população de pacientes 
odontológicos das Universidades de Nova lorque e Hong Kong. Nestes estudos, respectivamente, 17 casos foram detectados em 60.000 pacientes por ZEGARELLI et al. ${ }^{132}$, em 1966, e 20 casos em 110.000 por MACDONALD-JANKOWSKI71, em 1995.

A explicação de tantos casos envolvidos com o tratamento ortodôntico pode ser a seguinte: Em primeiro lugar, a deteç̧ão das lesões é resultante da sistematizada documentação ortodôntica à qual os pacientes são submetidos para planejamento e controles. A segunda razão envolve a interpretação da Tabela 5.10 e da Figura 5.12 e da Tabela e Figura 5.3, nas quais percebe-se que é na segunda década da vida, que se concentram os pacientes na "idade ortodôntica", o mesmo ocorrendo com a maior prevalência do cisto ósseo traumático. Disso tudo sobra apenas uma inferência clínica consistente. Se o tratamento ortodôntico não pode ser implicado na etiopatogenia do cisto ósseo traumático, parece claro tratar-se de uma doença cuja suspeita e/ou diagnóstico são, principalmente, atributo dos ortodontistas. Cabe pois, a difusão do conhecimento dessa lesão entre os ortodontistas para que os pacientes sejam os beneficiados. 


\section{7-CONCLUSÕES}




\section{CONCLUSÕES}

A partir dos resultados obtidos, considerando-se a metodologia empregada e a literatura pertinente sobre o cisto ósseo traumático, pôde-se constatar:

1. Houve evidências de uma prevalência semelhante do cisto ósseo traumático em relação ao gênero;

2. O cisto ósseo traumático ocorreu predominantemente na raça branca, porém observou-se uma relação entre lesões bilaterais e mulheres negras;

3. Dos 26 pacientes portadores de cisto ósseo traumático, 22 estavam na $2^{2}$ década de vida;

4. Na história clínica, $69,23 \%$ dos pacientes apresentaram alguma relação com 0 tratamento ortodôntico e apenas 30,77\% mencionaram história de trauma;

5. A localização principal da lesão foi o corpo mandibular;

6. As imagens radiográficas foram, principalmente, uniloculares e de forma oval;

7. Os nove casos clínicos compatíveis com o diagnóstico de cisto ósseo traumático, num período de proservação variando de três meses a três anos e seis meses, mostraram imagem estática ou em regressão;

8. Os seguintes critérios de proservação foram sugeridos: (a) Exame clínico e radiográfico 20 dias após a descoberta da lesão, sem sintomatologia constatável e com imagem radiográfica estável comparável àimagem de diagnóstico; (b) Exame clínico e 
radiográfico de 60 dias mantendo as características iniciais ou mostrando involução da lesão; (c) Exame clínico e radiográfico de seis meses mantendo as características iniciais ou de involução da lesão; (d) Controle de um ano ou mais, repetindo aspectos já mencionados.

9. Observou-se uma alta prevalência do cisto ósseo traumático em pacientes tratados ortodonticamente, porém, $50 \%$ dos casos foram diagnosticados na documentação ortodôntica inicial.

Assim, pode-se concluir: (1) o maior acesso da população ao tratamento odontológico especializado permite a detecção, mais freqüente, de lesões, até então, consideradas raras; (2) o ortodontista desempenha um papel importante no diagnóstico do cisto ósseo traumático. 
REFERÊNCIAS BIBLIOGRÁFICAS 


\section{REFERÊNCIAS BIBLIOGRÁFICAS*}

1. ABBOT, P.V. Traumatic bone cyst: case report. Endod. dent. Traumat., v.8, n.4, p.170-5, Aug. 1992.

2. AKIMOTO, Y. et al. Solitary bone cyst in the anterior mandible. J. Nihon Univ. Sch. Dent., v.28, n.3, p.199-202, Sept. 1986.

3. ALLWEIN, J.B. Traumatic cyst. Oral Surg., v.62, n.6, p.739-40, Dec. 1986.

4. AUSTIN, E.U. Hemorrhagic extravasation cyst of the mandible. Oral Surg., v.8, p.958-61, Sept. 1955.

5. BEASLEY, J.D. Traumatic cyst of the jaws: report of 30 cases. J. Amer. dent. Ass., v.92, n.1, p.145-52, Jan. 1976.

6. BERNIER, J.L.; JOHNSON, L.C. Comments on Dr. John G. Whinery's paper, "progressive bone cavities of the mandible". Oral Surg., v.8, p.970-2, Sept. 1955.

7. BIEWALD, H.F. A variation in management of hemorrhagic, traumatic, or simple bone cyst. J. oral Surg., v.25, p.427-38, Sept. 1967.

8. BLUM, B. Traumatic and idiopathic bone cysts. N. Y. St. dent. J., v.34, p.204-8, Apr. 1968.

9. BLUM, T. An additional report on traumatic bone cysts. Also a discussion of Dr. John G. Whinery's paper "progressive bone cavities of the mandible". Oral Surg., v.8, p.917-39, Sept. 1955.

10. BLUM, T. Unusual bone cavities in the mandible: a report of three cases of traumatic bone cysts. J. Amer. dent Ass., v.19, n.2, p.281-301, Feb. 1932.

\footnotetext{
" Normas recomendadas para uso no âmbito da Universidade de São Paulo, com base no documento "Referências Bibliográficas: exemplos", emanado do Conselho Supervisor do Sistema Integrado de Bibliotecas da USP, em reunião de 20 de setembro de 1990.
} 
11. BLUM, T. Do all cysts in the jaws originate from the dental system? (with a report of two non-dental cysts lined with ciliated columnar epithelium). J. Amer. dent Ass., v.16, n.4, p.647-61, Apr. 1929.

12. BRADLEY, J.C. Solitary bone cyst of the zigomatic bone. Brit. dent. J., v.152, n 6, p.203-4, Mar. 1982.

13. BRANNON, R.B.; HOUSTON, G.D. Bilateral traumatic bone cysts of the mandible: an unusual clinical presentation. Military Medicine, v.156, n.1, p.20-22, Jan. 1991.

14. BREEN, G.H.; ADDANTE, R. A recurrent traumatic bone cyst: report of case. J. Dent. Child., v.61, n.2, p.141-5, Mar./Apr. 1994.

15. CHAPMAN, P.J.; ROMANIUK, K. Traumatic bone cyst of the mandible; regression following aspiration. Int. J. oral Surg., v.14, n.3, p.290-4, June. 1985.

16. CHOUKAS, N.C.; ROMANO, J. Idiopathic bone cavities. J. oral Surg., v.36, n.1, p.33-5, Jan. 1978.

17. COHEN, M.A. Hemorrhagic (traumatic) cyst of the mandible associated with a retained root apex. Oral Surg., v.57, n.1, p.26-7, Jan. 1984.

18. COWAN, C.G. Traumatic bone cysts of the jaws and their presentation. Int. J. oral Surg., v.9, n.4, p.287-91, Aug. 1980.

19. CUDIA, G.; GORDEEFF, A.; PANZONI, E. Le kyste osseux solitaire. Une obsevation àdouble localisation mandibulaire et humerale. Rev. Stomat. Chir. maxillo-fac., v.88, n.1, p.31-5, 1987.

20. DARAMOLA, J.O. et al. Case 22, Part 1. J. oral Surg., v.36, n.3, p.210-1, Mar. 1978. 
21. DARAMOLA, J.O. et al. Case 22, Part 2 Traumatic cyst of the mandible. J. oral Surg., v.36, n.4, p.282-4, Apr. 1978.

22. DAVIDOVITCH, Z. Tooth movement. Critc. Rev. oral Biol. Med., v.2, n.4, p.411-50, 1991.

23. DAVIS, JR. W.McL., BUCHS, A.U.; DAVIS, W.McL. Extravasation cyst diagnostic curettement: a treatment. Report of 15 cases and suggested treatment. Oral Surg., v.47, n.1, p.2-7, Jan. 1979 .

24. DETOMASI, D.; HANN, J.R. Traumatic bone cyst: report of case. J. Amer. dent. Ass., v.111, n.1, p.56-7, July. 1985.

25. DONKOR, P.; PUNNIA-MOORTHY, A. Biochemical analysis of simple bone cyst fluid: report of a case. Int. J. oral Maxillofac. Surg., v.23, n.5, p.96-7, Oct. 1994.

26. FEINBERG, S.E. et al. Recurrent "traumatic" bone cyst of the mandible. Oral Surg., v.57, n.4, p.418-22, Apr. 1984.

27. FERREIRA. A.B.H. Novo dicionário da língua portuguesa. 2.ed. rev. ampl. Rio de Janeiro, Nova Fronteira, 1986.

28. FIELDING, C.G. The traumatic bone cyst: review of the literature and report of two cases. Military Medicine, v.157, n.12, p.676-80, Dec. 1992.

29. FISHER, A.D. Bone cavities in fibro-osseous lesions. Brit. J. oral Surg., v.14, n.2, p.120-7, Nov. 1976.

30. FORDYCE, G.L. Haemorragic cyst of the mandible. Brit. J. oral Surg., v.2, p.80-5, Nov. 1964.

31. FORSSEL, K. et al. Simple bone cyst: review of the literature and analysis of 23 cases. Int. J. oral Maxillofac. Surg., v.17, n.1, p.21-4, Feb. 1988.

32. FREEDMAN, G.L.; BEIGLEMAN, M.B. The traumataic bone cyst: a new dimension. Oral Surg., " ha n G n G16-8 luno 1085 
v.59, n.6, p.616-8, June 1985.

33. FRIEDRICHSEN, S.W. Long-term progression of a traumatic bone cyst. Oral Surg., v.76, n.4, p.421-4, Oct. 1993.

34. FRIEDRICHSEN, S.W. Traumatic bone cyst or Stafne's defect. Letter. Oral Surg., v.77, n.5, p.441, May 1994.

35. GAIT, C. Solitary bone cyst of the mandible - report of a case. Brit. J. oral Surg., v.13, n.3, p.2503, Mar. 1976.

36. GARCIA FILHO, , R.J. et al. Conservative treatment of solitary bone cysts - a study of 55 patients. Rev. paul. Med., v.110, n.3, p.131-7, May/June 1992.

37. GARDNER, A.F.; STOLLER, S.M.; STEIG, J.M. A study of the traumatic bone cyst of the jaws. J. Can. dent. Ass., v.28, n.3, p.151-66, Mar. 1962.

38. GOODSTEIN, D.B.; HIMMELFARB, R. Paresthesia and the traumatic bone cyst. Oral Surg., v.42, n.4, p.442-5, Oct. 1976.

39. GORLIN, R.J.; GOLDMAN, H.M. Cysts of the jaws oral floor and neck. In: Thoma's Oral Pathology. 6.ed. Saint. Louis, C.V.Mosby Company, 1970. Cap.10, p.471-3.

40. GOWGIEL, J.M. Simple bone cyst of the mandible. Oral Surg., v.47, n.4, p.319-22, Apr. 1979.

41. GRASSO, A.M.; DEMKEE, D.; FINNEGAN, J. Traumatic cyst of the mandible: report of case. J. oral Surg., v.27, n.5, p.341-4, May 1969.

42. HALL A.M. The solitary bone cyst: report of two cases. Oral Surg., v.42, n.2, p.164-8, Aug. 1976.

43. HANSEN, L.S.; SAPONE, J.; SPROAT, R.C. Traumatic bone cysts of jaws: report of sixty-six

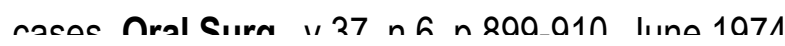


cases. Oral Surg., v.37, n.6, p.899-910, June 1974.

44. HARA, H.; OHISHI, M.; HIGUCHI, Y. Fibrous dysplasia of the mandible associated with large solitary bone cyst. J. oral Maxillofac. Surg., v.48, n.1, p.88-91, Jan. 1990.

45. HARRIS, S.J.; CARROLL, K.O.; GORDY, F.M. Idiopathic bone cavity (traumatic bone cyst) with the radiographic apperance of a fibro-osseous lesion. Oral Surg., v.74, n.1, p.118-23, July 1992.

46. HARRIS, W.E. Unusual response to treatment of a traumatic bone cyst: report of a case. J. Amer. dent. Ass., v.84, p.632-5, Mar. 1972.

47. HEIMDAHL, A. An unusual case of "simple bone cyst" of the mandible. Int. J. oral Surg., v.7, n.1, p.32-5, Feb. 1978.

48. HERD, J.R. The traumatic bone cyst. Aust. dent. J., v.22, n.5, p.373-7, Oct. 1977.

49. HIGUCHI, Y.; NAKAMURA, N.; TASHIRO, H. Clinicopathologic study of cemento-osseous dysplasia producing cysts of the mandible. Report of four cases. Oral Surg., v.65, n.3, p.33942, Mar. 1988.

50. HILLERUP, S.; HJORTING-HANSEN, E. Aneurysmal bone cyst-simple bone cyst, two aspect of the same pathologyc entity? Int. J. oral Surg., v.7, n.1, p.16-22, Feb. 1978.

51. HOSSEINI, M.; Two atypical solitary bone cysts. Brit. J. oral Surg., v.16, n.3 , p.262-9, Mar. 1978.

52. HOWE, G.L. "Haemorrhagic cysts" of the mandible - I. Brit. J. oral Surg., v.3, p.55-76, Nov. 1965.

53. HOWE, G.L. "Haemorrhagic cysts" of the mandible - II. Brit. J. oral Surg., v.3, p.77-91, Nov. 1965.

54. HUEBNER, G.R.; TURLINGTON, E.G. So-called traumatic (hemorrhagic) bone cysts of the jaws.

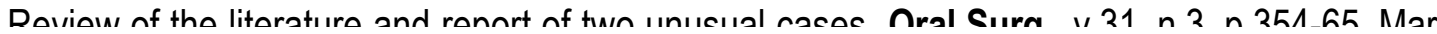


Review of the literature and report of two unusual cases. Oral Surg., v.31, n.3, p.354-65, Mar. 1971.

55. HUGHES, C.L. Hemorrhagic bone cyst and pathologic fracture of mandible; report of case. J. oral Surg., v.27, n.5, p.345-6, May 1969.

56. JACOBS, M.H. Traumatic bone cyst. Oral Surg., v.8, p.940-9, Sept. 1955.

57. JACOBS, M.H.; STONE, H. Cysts of the jaws. Amer. J. Orthodont. oral Surg., v.26, p.690-711, July 1940.

58. JAFFE, H.L. Giant-cell reparative granuloma, traumatic bone cyst, and fibrous (fibro-osseous) dysplasia of the jaw bones. Oral Surg., v.6, p.159-75, Jan. 1953.

59. JAFFE, H.L.; LICHTENSTEIN, L. Solitary unicameral bone cyst. Arch. Surg., v.44, p.1004-25, 1942.

60. JONES, A.C.; BAUGHMAN, R.A. Multiple idiopathic mandibular bone cysts in a patient with osteogenesis imperfecta. Oral Surg., v.75, n.3, p.333-7, Mar. 1993.

61. KAUGARS, G.E; CALE, A.E. Traumatic bone cyst. Oral Surg., v.63, n.3, p.318-24, Mar. 1987.

62. KERR, D.A. Comments on traumatic bone cysts. Oral Surg., v.8, p.967-8, Sept. 1955.

63. KHOSLA, V.M. Hemorrhagic bone cyst of mandible: report of a case. Oral Surg., v.30, n.6, p.7239, Dec. 1970.

64. KUROI, M. Simple bone cyst of the jaw: review of the literature and report of case. J. oral Surg., v.38, n.6, p.456-9, June. 1980.

65. KUTTENBERGER, J.J.; FARMAND, M.; STÖSS, H. Recurrence of a solitary bone cyst of the mandibular condyle in a bone graft. A case report. Oral Surg., v.74, n.5, p.550-6, Nov. 1992. 
66. LAZANSKY, J.P.; WUEHRMANN, A.H.; GLICKMAN, I. Traumatic cyst of the mandible. Amer. J. Orthodont. oral Surg., v.32, p.155-9, Mar. 1946.

67. LILLY, G.E.; OSBON, D.B. Traumatic cyst: report of a case. Oral Surg., v.35, n.5, p.606-10, May 1973.

68. LINDSAY, J.S.; MARTIN, W.R.; GREEN, H.G. Traumatic bone cyst treated with homogenous bone graft. Report of a case. Oral Surg., v.21, n.4, p.536-42, Apr. 1966.

69. LUDWIG, A.; MERTEN, H.A. Solitarë knochenzsten: pathogenese, klinik und therapie der Solitarën knochenzste. Schweiz Monatsschr Zahnmed, v.105, n.1, p.63-70, 1995.

70. MACDONALD-JANKOWSKI, D.S. Traumatic bone cysts in the jaws of Hong Kong Chinese population. Clin. Radiol., v.50, n.11, p.787-91, Nov. 1995.

71. MARKUS, A.F. Bilateral haemorrhagic bone cysts of the mandible: a case report. Brit. J. oral Surg., v.16, n.3, p.270-3, Mar. 1979.

72. MATISE, J.L. et al. Pathologic fracture of the mandible associated with simultaneous occurrence of an odontogenic keratocyst and traumatic bone cyst. J. oral Maxillofac. Surg., v.45, n.1, p.6971, Jan. 1987.

73. MELROSE, R.J.; ABRAMS, A.M.; MILLS B.G. Florid osseous dysplasia. A clinical-pathologic study of thirty-four cases. Oral Surg., v.41, n.1, p.62-82, Jan. 1976.

74. MILES, D.A. Traumatic bone cyst or Stafne's defect. Letter. Oral Surg., v.77, n.5, p.440, May 1994.

75. MIURA, F. et al. The super-elastic property of the Japanese NiTi alloy wire for use in orthodontics.

Amer. J. Orthodont. Dentofac. Orthop., v.90, n.1, p.1-10, July 1986.

76. MIYAUCHI, M. et al. Florid cemento-osseous dysplasia with concomitant simple bone cysts: a case

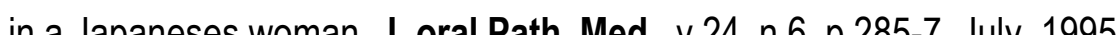


in a Japaneses woman. J. oral Path. Med., v.24, n.6, p.285-7, July, 1995.

77. MONTEBUGNOLI, L.; VACCARO, M.A.; PELLICCIONI, G.A. Cisti solitaria dei mascellari. Dent. Cadm., v.39, n.5, p.85-9, Mar. 1991.

78. MORRIS, C.R.; STEED, D.L.; JACOBY, J.J. Traumatic bone cysts. J. oral Surg., v. 28, n.3, p.18895, Mar. 1970.

79. MOSS, M.; LEVEY, A.C. The traumatic bone cyst: report of three cases. J. Amer. dent. Ass., v.72, p.397-402, Feb. 1966.

80. MOULE, I. Unilateral multiple solitary bone cyst. J. oral Maxillofac. Surg., v.46, n.4, p.320-3, Apr. 1988.

81. NARANG, R.; JARRETT, J.H. Large traumatic bone cyst of the mandible. J. oral Surg., v.38, n.8, p.617-8, Aug. 1980.

82. NEWTON, C.W.; ZUNT, S.L. Endodontic intervention in the traumatic bone cyst. J. Endod., v.13, n.8, p.405-8, Aug. 1987.

83. NORTJÉ, C.J.; FARMAN, A.G.; JOUBERT, J.J.V. The xeroradiographic apperance of simple bone cyst of the mandible. Oral Surg., v.45, n.3, p.485-7, Mar. 1978.

84. OLECH, E.; SICHER, H.; WEINMANN, J.P. Terminology of the so-called traumatic bone cyst. Oral Surg., v.8, p.962, Sept. 1955.

85. OLECH, E.; SICHER, H.; WEINMANN, J.P. Traumatic mandibular bone cysts. Oral Surg., v.4, p.1160-72, Sept. 1951.

86. O'NEIL, R. Solitary bone cavity. Brit. dent. J., v.124, p.357-8, Apr. 1968.

87. PATRIKIOU, A.; SEPHERIADOU-MAVROPOULOU, Th.; ZAMBELIS, G. Bilateral traumatic bone cyst of the mandible, Oral Surg., v.51, n.2, p.131-3, Feb. 1981. 
88. PERSSON, G. An atypical solitary bone cyst. J. oral Maxillofac. Surg., v.43, n.11, p.905-7, Nov. 1985.

89. POGREL, M.A. Bilateral solitary bone cysts: report of case. J. oral Surg., v.36, n.1, p.55-8, Jan. 1978.

90. POGREL, M.A. A solitary bone cyst possibly caused by removal of impacted third molar. J. oral Maxillofac. Surg., v.45, n.8, p. 721-3, Aug. 1987.

91. POYTON, H.G.; MORGAN G.A. The simple bone cyst. Oral Surg., v.20, n.2, p.188-97, Aug. 1965.

92. PRECIOS, D.S.; McFADDEN, L.R. Treatment of traumatic bone cyst of mandible by injection of autogeneic blood. Oral Surg., v.58, n.2, p.137-40, Aug. 1984.

93. PRICE, C. Traumatic bone cyst or Stafne's defect. Letter. Oral Surg., v.77, n.5, p.440, May 1994.

94. PROFFIT, W.R.; FIELDS, JR. H.W. As bases biológicas da terapia ortodôntica. In: Ortodontia Conteporânea. 2.ed. Rio de Janeiro, Guanabara Koogan, 1995. Cap.9, p.244-264.

95. RAIBLEY, S.O.; BECKETT, R.P.; NOWAKOWSKY, A. Multiple traumatic bone cyst of the mandible. J. oral Surg., v. 37, n.5, p.335-7, May 1979.

96. REITAN, K.; RYGH, P. Biomechanical principles and reactions. In: GRABER, T.M.; VANARSDALL JR., R.L. Orthodontics. Current principles and thechniques. 2.ed. Saint. Louis, C.V.Mosby Company, 1994. Cap.2, p.96-192.

97. REYCHLER, H. Revue des pseudo-kystes et lacunes osseuses des maxillaires. Rev. Stomat. Chir. maxillo-fac., v.89, n.4, p.190-8, 1988.

98. ROBINSON, M.; CANTER, S.; SHUKEN, R. Multiple progressive bone cyst of the mandible and maxilla. Oral Surg., v.23, n.4, p.483-6, Apr. 1967.

99. ROCHA, W.C.; MORANDI, R.; MENDONÇA, E.F. Cisto ósseo traumático: relato de caso. Rev. 
Odontol. Brasil Central, v.6, n.19, p.32-4, set. 1996

100. ROME, W.J.; SWAN, R.H.; BEEHNER, M.E. Idiopathic bone cavity associated with a necrotic pulp and facial cellulitis. J. Endod., v.9, n.8, p.332-4, Aug. 1983.

101. RUIZ-HUBARD, E.E.; HARRISON, J.W. Healing of a traumatic bone cyst after nonsurgical endodontic treatment. J. Endod., v.13, n.1, p.40-2, Jan. 1987.

102. RUPRECHT, A.; REID, J. Simple bone cyst: report of two cases. Oral Surg., v.39, n.5, p.826-31, May 1975.

103. RUSHTON, M.A. Solitary bone cysts in the mandible. Brit. dent. J., v.81, n.19, p.37-49, July 1946.

104. RUSIECKI, R.S. Traumatic bone cyst in a 13 year old male. J. Pedod., v. 11, n.3, p.281-7, Spring 1987.

105. SAITO, Y. et al. Simple bone cyst: a clinical and histopathologic study of fifteen cases. Oral Surg., v.74, n.4, p.487-91, Oct. 1992.

106. SAPP, J.P.; STARK, M.L. Self-healing traumatic bone cysts. Oral Surg., v.69, n.5, p.597-602, May 1990.

107. SCHOFIELD, I.D.F. An unusual traumatic bone cyst. Oral Surg., v.38, n.2, p.198-203, Aug. 1974.

108. SCHWARZ, A.M. Tissue changes incidental to ortothodontic thooth movement. Int. J. Orthodont., v.18, p.331-52, 1932.

109. SHARMA, J.N. Hemorrhagic cyst of the mandible in relation to horizontally impacted third molar. Oral Surg., v.55, n.1, p.17-8, Jan. 1983.

110. SHARMA, J.N. Hemorrhagic cyst of the mandible: report of a case. Oral Surg., v.24, n.2, p.211-5, Aug. 1967. 
111. SHEAR, M. Cysts of the oral regions. 3.ed. Oxford, Wright PSG, 1992.

112. SHIGEMATSU, H.; FUJITA, K.; WATANABE, K. Atypical simple bone cyst of the mandible: a case report. Int. J. oral Maxillofac. Surg., v.23, n.5, p.298-9, Oct. 1994.

113. STEWART, S.; SHERMAN. P.; STOOPACK, J.C.; Large bilateral traumatic bone cysts of the mandible: report of a case. Oral Surg., v.31, n.11, p.865-8, Nov. 1973.

114. STIMSON, P.G.; McDANIEL, R.K. Traumatic bone cyst, aneurysmal bone cyst, and central giant cell granuloma pathogenetically related lesions? J. Endod., v.15, n.4, p.164-7, Apr. 1989.

115. SUEI, Y.; TANIMOTO, K.; WADA, T. Simple bone cyst. Evaluation of contents with conventional radiography and computed tomography. Oral Surg., v.77, n.3, p.296-301, Mar. 1994.

116. SZERLIP, L. Traumatic bone cysts. resolution without surgery. Oral Surg., v.21, n.2, p.201-4, Feb. 1966.

117. TANAKA, H. et al. Simple bone cyst of the mandibular condyle: report of a case. J. oral Maxillofac. Surg., v.54, n.12, p.1454-8, Dec. 1996.

118. TELFER, M.R. et al. Primary bone cyst of the mandibular condyle. Brit. J. oral Maxillofac. Surg., v.28, n.5, p.340-3, Oct. 1990.

119. THOMA, K.H. Bone cysts. In: Oral Surgery. 4.ed. Saint. Louis, Mosby, 1963. Cap.36, p.896-903.

120. THOMA, K.H.; GOLDMAN, H.N. Local diseases of the jaws. In: Oral Pathology. 5.ed. Saint. Louis, Mosby, 1960. Cap.21, p.766-71.

121. THOMA, K.H. Treatment of extravasation cysts with the use of gelfoam. Editorial. Oral Surg., v.8, p.950-4, Sept. 1955.

122. THOMA, K.H. Treatment of extravasation cyst. Editorial. Oral Surg., v.8, p.899-902, Sept. 1995. 
123. THOMA, K.H. A symposium on bone cyst. Editorial. Oral Surg., v.8, p.899-902, Sept. 1955.

124. TOLLER, P.A. Radioactive isotope and other investigations in a case of haemorrhagic cyst of the mandible. Brit. J. oral Surg., v.2, p.86-93, Nov. 1964.

125. VIAZIS, A.D. Bioefficient therapy. J. clin. Orthodont., v.29, n.9, p.552-68, Sept. 1995.

126. VIJAYRAGHAVAN, K.; WHITLOCK, R.I.H. An unusual case of "haemorrhagic"bone cyst. Brit. J. oral Surg., v.13, n.1, p.64-72, July 1975.

127. WALDRON, C.A. Fibro-osseous lesions of the jaws. J. oral Maxillofac. Surg., v.43, n.4, p.249-62, Apr. 1985.

128. WALDRON, C.A. Comments on Dr. Whinery's paper (Progressive bone cavities of mandible). Oral Surg., v.8, p.955-7, Sept. 1955.

129. WALDRON, C.A. Solitary (hemorrhagic) cyst of the mandible. Oral Surg., v.7, p.88-95, Jan. 1954.

130. WHINERY, J.G. Pogressive bone cavities of the mandible. A review of the so-called traumatic bone cyst and a report of three cases. Oral Surg., v.8, p.903-16, disc. 917-39, 955-7, 970-2, Sept. 1955.

131. WINER, R.A.; DOKU, H.C. Traumatic bone cyst in the maxilla. Oral Surg., v.46, n.3, p.367-70, Sept. 1978.

132. ZEGARELLI, E.V.; KUTSCHER, A.H.; TENORE, R.A. Idiopatic bone cyst. N. Y. St. J. Med., v.66, p.1753-6, July 1966. 
$\underline{\text { ABSTRACT }}$ 


\section{ABSTRACT}

A research about the traumatic bone cyst (TBC) of the jaws was realized with the following purpose: (1) To determine the epidemiology of the sample studied regarding gender, race, age, clinical history, location, and radiographic image shape. (2) To discuss the possibility of self-healing of the TBC, determining criteria for diagnosis and follow-up without surgical intervention. (3) To study the frequency of TBC in orthodontic treated patients and discuss its possible etiopathogenic relationship. The material was constituted by two sample. The sample number one was composed of 28 cases of TBC, being 19 cases confirmed by surgical procedure, and 9 valid cases of TBC determined by clinical and radiographic features and follow-up information. The sample number two was constituted by cases found in 956 orthodontic treated patients. The results concerning sample number one allowed us to verify that: (1) there was a lack of gender predilection; (2) TBC affected most frequently white patients, although bilateral lesions were more likely to occur in black women; (3) 22 patients were in second decade; (4) 69.23 per cent of the reported cases were involved in orthodontic treatment, and 30.77

per cent showed a positive history of trauma; (5) the favorite anatomic location was the body of the mandible, showing unilocular oval-shaped radiolucencies; (6) the follow-up of the lesions without surgical intervention suggested static images or images in regression. The results concerning sample number two showed a high frequency of TBC in orthodontic treated patients, though 50 per cent of the cases were detected in the initial orthodontic records. Therefore, it is possible to conclude that: (1) access of the population to specialized dental treatment reveals more lesions than it was previously thought there could be; (2) the orthodontist plays an important part in the diagnosis of the TBC. 